JEFFERSON BRUNO PEREIRA RIBEIRO

\begin{abstract}
AVALIAÇÃO IN VIVO DA EFICÁCIA DO TRATAMENTO COM MILTEFOSINA SISTÊMICO ASSOCIADO À TERAPIA FOTODINÂMICA COM FTALOCIANINA CLORO-ALUMÍNIO DE FORMULAÇÃO LIPOSSOMAL (AICIFt) CONTRA O PARASITA Leishmania (L.) amazonensis
\end{abstract}




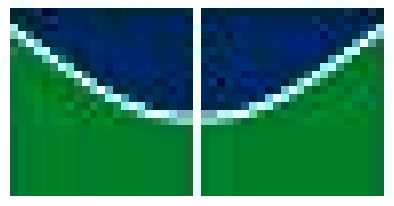

UNIVERSIDADE DE BRASÍLIA

FACULDADE DE CIÊNCIAS MÉDICAS

PROGRAMA DE PÓS-GRADUAÇÃO EM CIÊNCIAS MÉDICAS

JEFFERSON BRUNO PEREIRA RIBEIRO

\title{
AVALIAÇÃO IN VIVO DA EFICÁCIA DO TRATAMENTO COM MILTEFOSINA SISTÊMICO ASSOCIADO À TERAPIA FOTODINÂMICA COM FTALOCIANINA CLORO-ALUMÍNIO DE FORMULAÇÃO LIPOSSOMAL (AICIFt) CONTRA O PARASITA Leishmania (L.) amazonensis
}

\begin{abstract}
Dissertação de mestrado apresentada ao Programa de Pós-Graduação em Ciências Médicas da Faculdade de Medicina da Universidade de Brasília como requisito parcial para obtenção do grau de mestre.
\end{abstract}

Orientadora: Professora Doutora Raimunda Nonata Ribeiro Sampaio Co-orientadora: Professora Doutora Ana Luisa Miranda-Vilela

Brasília 


\title{
AVALIAÇÃO IN VIVO DA EFICÁCIA DO TRATAMENTO COM MILTEFOSINA SISTÊMICO ASSOCIADO À TERAPIA FOTODINÂMICA COM FTALOCIANINA CLORO-ALUMÍNIO DE FORMULAÇÃO LIPOSSOMAL (AICIFt) CONTRA O PARASITA Leishmania (L.) amazonensis
}

Aprovada em 20 de novembro de 2014.

Banca Examinadora:

\author{
Professora Dra. Raimunda Nonata Ribeiro Sampaio \\ Presidente/ Orientadora \\ Faculdade de Medicina/ Universidade de Brasília
}

Professora Dra. Ana Luisa Miranda-Vilela

Co-orientadora

Departamento de Genética e Morfologia/ Universidade de Brasília

Professor Dr. Ciro Martins Gomes Membro Externo

HC Universidade de São Paulo - Ribeirão Preto
Professora Dra Maria Imaculada Muniz Barbosa Junqueira Membro Interno Universidade de Brasília 
Dedico este estudo a Deus e aos meus pais. 


\section{AGRADECIMENTOS}

Agradeço primeiramente e, sobretudo, a Deus, por todas as oportunidades que tem me dado e por estar sempre ao meu lado. Deus Este que eu acredito e humildemente tento seguir em todos os momentos

Agradeço a São Francisco de Assis pela ajuda no manuseio dos animais.

Agradeço à professora Raimunda Nonata Ribeiro Sampaio, não só por todo o ensinamento, mas por todos os puxões de orelha, muitas vezes severos e incisivos tenham sido, e que sempre me direcionaram ao caminho correto. Agradeço-a, ainda, por me ter aberto as portas da Universidade de Brasília e por acreditar em meu trabalho como pesquisador. E não poderia deixar de registrar todas as contribuições feitas para o tratamento de leishmaniose, doença responsável pela morte de milhares de animais todos os anos no Brasil e no mundo.

Agradeço à professora Ana Luisa Miranda-Vilela, que em momentos de extremo desespero conseguiu me amparar e direcionar-me aos caminhos corretos. Agradeço ainda a todos os ensinamentos e contribuições de importante relevância para a elaboração deste trabalho. Também agradeço ao professor Cláudio Tedesco, do Departamento de Química da Universidade de São Paulo, Ribeirão Preto, que gentilmente manipulou e cedeu a ftalocianina de cloro-alumínio em formulação lipossomal para viabilizar a realização desta pesquisa.

Agradeço aos 30 animais deste estudo que involuntariamente foram submetidos a todo o processo deste trabalho.

Aos meus pais, José Maria Ribeiro e Maria Silvana Pereira, que apesar de todas as dificuldades, conseguiram sempre viver com muita honestidade e dignidade e serem minhas referências de formação como pessoa e ser humano.

Aos meus irmãos, Gabriel Bruno e Jéssica Bruna, pelo companheirismo em momentos difíceis.

Às minhas duas avós, Maria Martins e Maria Aparecida, por todas as orações, direcionadas a mim.

Aos meus tios Gilliard André e Jaqueline Síntia, e minha prima Helen Cristina, pela compreensão, paciência e apoio. Aos meus amigos Amarildo Jorge, Adriana Mesquita, Salatieu Eurípedes, Marilene Curado, muito obrigado. 
A um grande amigo de todas as horas Jonathan Rosa Moreira, pela indispensável ajuda sem a qual não teria sido possível realizar este trabalho e por ter se tornado um exemplo acadêmico a ser seguido.

Agradeço a proteção de Nossa Senhora Aparecida que sempre intercede por $\operatorname{mim}$.

Agradeço à dedicada Médica Veterinária Gabriela Mariângela, pelos ensinamentos na manipulação de animais em laboratório.

Ao professor João Paulo Figueiró Longo, do Departamento de Biologia da Universidade de Brasília, que gentilmente cedeu seu aparelho de laser tornando viável a realização deste estudo.

Agradeço às futuras brilhantes médicas e parceiras de pesquisas, Ana Angélica Santerem Amorim e Rafaela Debastiani Garcia, que com grande comprometimento contribuíram em diversos momentos desta pesquisa. E assim aproveito para agradecer aos técnicos de laboratório, Viviane e Técio, pela valorosa contribuição com seus conhecimentos altamente especializados.

À CAPES, por oportunizar-me bolsa de estudos em pesquisa durante 0 período regular para realização deste estudo. Agradeço também à UnB, UNICAMP, ao HUB e ao Departamento de Genética e Morfologia (UnB) por permitirem a irreparável atuação de seus profissionais neste estudo.

Agradeço as minhas cinco lindas cachorrinhas (Tonton Bolinha, Sardinha Bruna, Brigitte Bardot, Sanduba Neném e Bianca Rosa) por suportarem minhas ausências prolongadas para dedicar-me à aplicação desta pesquisa.

Obrigado. 
"Por muitos triunfos que consiga a mente, por muitos dons que enriqueçam a humanidade, não haverá no transcurso dos séculos, uma hora mais doce do que aquela em que a esperança, a dúvida e o amor contemplaram, em meio a um profundo silêncio, a um cérebro audaz decretar com vontade quase divina a morte da dor."

Weir Mitchell (1896). 


\section{LISTA DE FIGURAS}

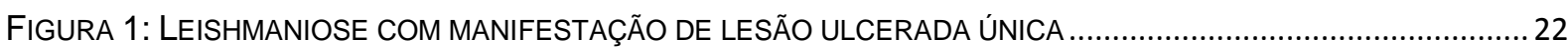

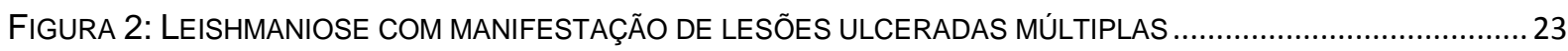

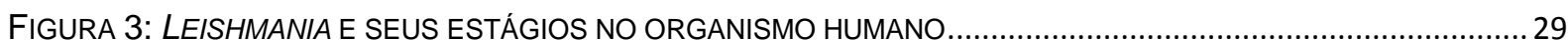

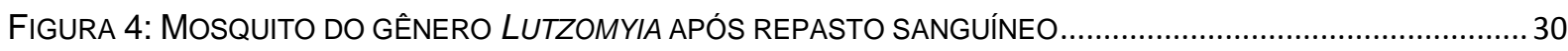

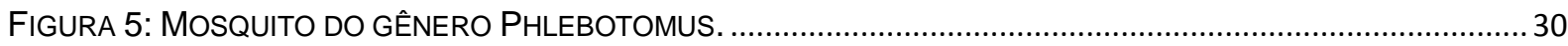

FIGURA 6: DESENHO DO FUNCIONAMENTO DA REAÇÃO FOTOQUÍMICA PRESENTE NA TFD, ONDE ESTÁ DESCRITA A PRODUÇÃO DE RADICAIS LIVRES APÓS A EXCITAÇÃO DO FS COM IRRADIAÇÃO A LASER......... 35

FIGURA 7: CÂMARA DE CONTAGEM ADAPTADA PARA MICROSCÓPIO DE CAMPO CLARO. ..................................... 39

FIGURA 8: AMOSTRAS DE FTALOCIANINA DE CLORO-ALUMÍNIO EM FORMULAÇÃO LIMPOSSOMAL GELPC,

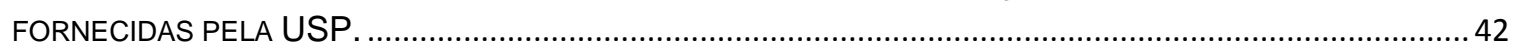

FIGURA 9: CAMUNDONGO FÊMEA ADULTA CEPA C57BL/6, ESPÉCIE MUS MUSCULUS, INFECTADA NO COXIM PLANTAR DIREITO VIA SUBCUTÂNEA, COM $3 \times 10^{6}$ FORMAS PROMASTIGOTAS DE LEISHMANIA

AMAZONENSIS, EM FASE METACÍCLICA, REGISTRADA COM 30 DIAS DE INFECÇÃO................................... 43

FIGURA 10: CAMUNDONGO C57BL/6 SEDADO SOB EXPOSIÇÃO À LUZ VISÍVEL ............................................... 46

FIGURA 11: FOLHA DE ALUMÍNIO E SUA APLICAÇÃO EM CAMUNDONGO C57BL/6 AGUARDANDO 15 MINUTOS

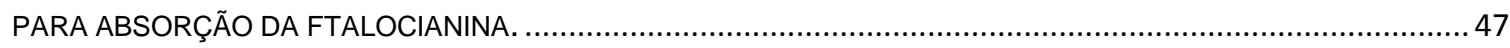

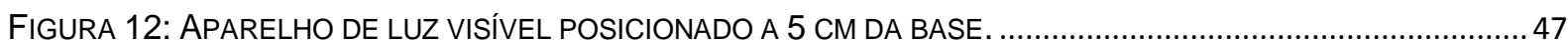

FIGURA 13: PAQUÍMETROS MILIMÉTRICO MITUTOYO® UTILIZADOS PARA MEDIDA DAS PATAS DOS ANIMAIS. .... 49

FIGURA 14: HOMOGENEIZADOR UTILIZADO PARA MACERAÇÃO DAS PATAS DOS CAMUNDONGOS.....................50

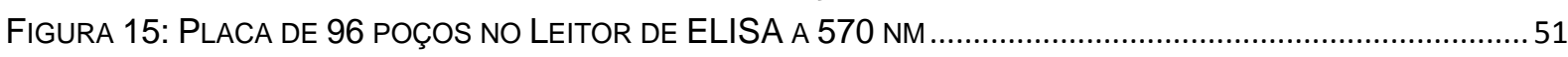

FIGURA 16: PRESENÇA DE FRAGMENTOS DO ALUMÍNIO NO FORMATO CÚBICO COM SUPERFÍCIE LISA ................53 


\section{LISTA DE QUADROS}

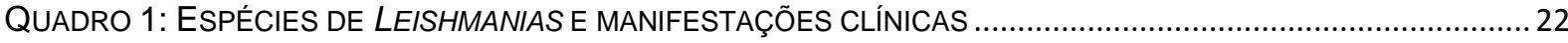

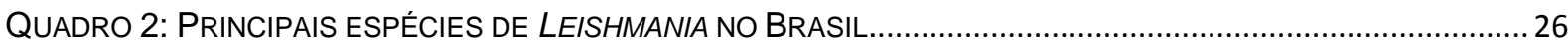

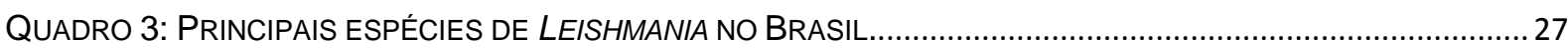

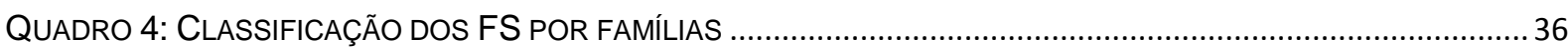

QUADRO 5: ESQUEMA COM PADRÕES GERAIS PARA O TRATAMENTO COM TERAPIA FOTODINÂMICA TÓPICA COM

FTALOCIANINA CLORO-ALUMÍNIO DE FORMULAÇÃO LIPOSSOMAL ASSOCIADAS À MILTEFOSINA. .................. 40

QUADRO 6: CARACTERIZAÇÃO DOS GRUPOS E ESQUEMA TERAPÊUTICO UTILIZADO. ....................................... 42 


\section{LISTA DE TABELAS}

TABELA 1: INCIDÊNCIA DE CASOS DE LTA (X1000.000 HABITANTES), POR MACRORREGIÃO. ........................... 25

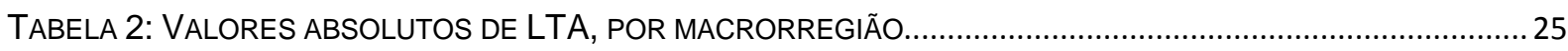

TABELA 3: CONFIRMAÇÃO DA INFECÇÃO DOS ANIMAIS POR LÂMINAS DE EXTENSÃO E CULTURA .........................44

TABELA 4: RELAÇÃO DE CULTURAS NEGATIVAS E POSITIVAS 30 DIAS APÓS A INFECÇÃO E AO FINAL DE 20 DIAS

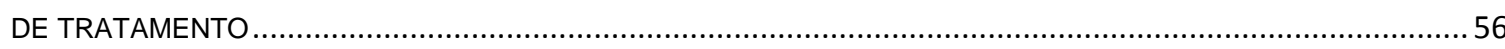

TABELA 5: RELAÇÃO DE LÂMINAS DE EXTENSÃO NEGATIVAS E POSITIVAS 30 DIAS APÓS A INFECÇÃO E AO FINAL

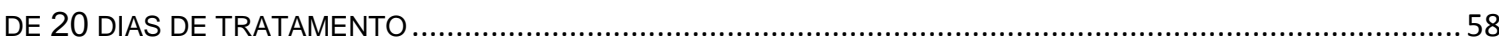




\section{LISTA DE GRÁFICOS}

GRÁFICO 1: DIÂMETRO MÉDIO DA SOLUÇÃO LIPOSSOMAL ANALISADA PELO MET.

GRÁFICO 2: DIÂMETRO DAS PATAS DOS ANIMAIS ANTES DA INFECÇÃO, APÓS 2 E 30 DIAS DE INFECÇÃO (CONFIRMAÇÃO DA INFECÇÃO) E APÓS 20 DIAS DE TRATAMENTO.

54

GRÁFICO 3: DISTRIBUIÇÃO DO NÚMERO DE PARASITAS POR PATA DE CAMUNDONGO C57BL/6 INFECTADOS

POR LEISHMANIA (L.) AMAZONENSIS.

59

GRÁFICO 4: DISTRIBUIÇÃO DO PERCENTUAL DE LEISHMANIAS VIÁVEIS POR PATA DE CAMUNDONGOS C57BL/6

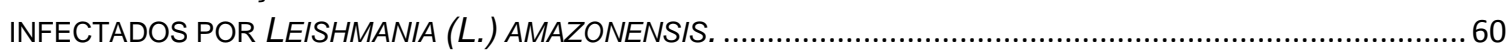




\section{LISTA DE ABREVIATURAS}

$\begin{array}{ll}\text { ADN } & \text { Ácido Desoxirribonucléico } \\ \text { ALA } & \text { Ácido aminolevulínico } \\ \text { ALPC } & \text { Cloreto de Alumínio Ftalocianina } \\ \text { CEMIB } & \text { Centro Multidisciplinar para Investigação Biológica } \\ \text { CEUA } & \text { Comitê de Ética em Pesquisa e Uso Animal } \\ \text { CIEX } & \text { Cirurgia Experimental } \\ \text { DNA } & \text { Deoxyribonucleic Acid } \\ \text { EDS } & \text { Energia Dispersiva de Raio-X } \\ \text { ERO } & \text { Espécie Reativa de Oxigênio } \\ \text { FM } & \text { Faculdade de Medicina } \\ \text { FS } & \text { Fotossensibilizador } \\ \text { HPPH } & \text { Photochlor } \\ \text { HUB } & \text { Hospital Universitário de Brasília } \\ \text { Idp } & \text { Índice de Polidispersão } \\ \text { LC } & \text { Leishmaniose Cutânea } \\ \text { LCD } & \text { Leishmaniose Cutânea Difusa } \\ \text { LMC } & \text { Leishmaniose Mucocutânea } \\ \text { LTA } & \text { Leishmaniose Tegumentar Americana } \\ \text { LV } & \text { Leishmaniose Visceral } \\ \text { LVA } & \text { Leishmaniose Visceral Americana } \\ \text { MET } & \text { Microscópio Eletrônico Transmissão } \\ \text { MEV } & \text { Microscópio de Varredura } \\ \text { MS } & \text { Ministério da Saúde } \\ \text { NAP } & \text { Núcleo de Apoio à Pesquisa } \\ \text { NNN } & \text { Nove-McNeal-Nicolle } \\ \text { OMS } & \text { Organização Mundial da Saúde } \\ \text { PBS } & \text { Controle Positivo } \\ \text { RNA } & \text { Ácido Ribonucleico } \\ \text { SFM } & \text { Sistema Fagocítico Mononuclear } \\ \text { SPSS } & \text { Statistical Package for the Social Sciences } \\ & \end{array}$




$\begin{array}{ll}\text { TFD } & \text { Terapia Fotodinâmica } \\ \text { UnB } & \text { Universidade de Brasília } \\ \text { UNICAMP } & \text { Universidade de Campinas } \\ \text { USP } & \text { Universidade de São Paulo } \\ \text { WHO } & \text { World Health Organization } \\ \text { ZnPc } & \text { Ftalocianina de Zinco }\end{array}$




\section{LISTA DE SÍMBOLOS}

$\begin{array}{ll}\mathrm{CO}_{2} & \text { Gás carbônico } \\ \mathrm{mg} & \text { Miligramas } \\ \mathrm{nm} & \text { Nanômetro } \\ \mathrm{Sb}^{\mathrm{v}} & \text { Antimônio pentavalente } \\ \mathrm{Sb}^{\text {III }} & \text { Antimonial trivalente } \\ { }^{\circledR} & \text { Registrado } \\ \mu \mathrm{L} & \text { Micro Litro }\end{array}$




\section{RESUMO}

A escassez de fármacos é uma preocupação e objeto de estudo para a descoberta de alternativas eficazes para o tratamento da leishmaniose cutânea (LC). A formulação tópica tem sido almejada devido sua baixa toxicidade. $O$ desenvolvimento de terapias alternativas, como a multimodal, é importante no enfrentamento da resistência às drogas. $O$ objetivo deste estudo foi comparar a eficácia in vivo da terapia fotodinâmica (TFD) tópica com ftalocianina cloro-alumínio lipossomal para o tratamento da LC, isoladamente e em associação com a terapia sistêmica com miltefosina. Foram formados 5 grupos, cada um com 6 camundongos isogênicos, adultos, fêmeas, da espécie Mus musculus, cepa C57BL/6: (1) Controle negativo, sem infecção e sem tratamento; (2) Controle positivo, infectado e não tratado; (3) Miltefosina $200 \mathrm{mg}$, diariamente, e TFD com ftalocianina cloro-alumínio lipossomal (FCL), em dias alternados; (4) Apenas Miltefosina; e (5) Apenas TFD com FCL. Os esquemas terapêuticos duraram 20 dias. Confirmou-se a infecção dos animais, realizando cultura em meio NNN da linfa colhida da pata dos animais. Vias de administração adotadas foram miltefosina oral e FCL tópica. Para a aplicação da TFD, os animais foram anestesiados com a associação de xilazina e quetamina. Os animais foram avaliados por: (i) medição das patas e (ii) critérios parasitológicos. As análises estatísticas foram realizadas com software SPSS $\AA_{\text {. }}$ O número de parasitas viáveis por pata foi determinado pelo programa $E$ lida®. Observou-se maior eficácia para o grupo que utilizou a associação de TFD com FCL e miltefosina $(p<0,05)$, no qual houve uma redução maior de parasitas quando comparada aos outros dois grupos, cujos resultados do tratamento foram semelhantes ao grupo controle negativo $(p<0,05)$. A TFD com $F C L$, quando usada isolada, demonstrou baixa eficácia quando comparada ao grupo controle negativo e grupo padrão ouro (miltefosina) $(p<0,05)$.

Palavras-chaves: Leishmaniose Cutânea; Miltefosina; Terapia Fotodinâmica; Ftalocianina Cloro-Alumínio Lipossomal; Nanodroga. 


\section{ABSTRACT}

Shortage of drugs is a concern and object of studies for the discovery of effective alternative for Cutaneous Leishmaniasis (CL) treatment. Topic formulation has been aimed due its low toxicity. Development of alternative therapies, as multimodal, is important to confront the drug resistance. This study aims to compare the in vivo effectiveness of topic photodynamic therapy (PDT) with liposomal chloro-aluminuim phthalocyanine (LCP) in treatment of $C L$, isolated and associated with systemic therapy with miltefosine. 5 groups were adopted each one with 6 isogenic adult female mice, Mus musculus species, C57BL/6: (i) Negative Control, without infection and without treatment; (ii) Positive Control, infected but not treated; (iii) Miltefosine 200mg, daily, and PDT with LCP on alternating days; (iv) only Miltefosine; and (v) only PDT with LCP. Therapeutic schemes lasted 20 days. Animal infection has been confirmed, performing culture in NNN of the collected lymph paw of animals. The adopted routes of administration were oral miltefosine and topic LCP. For PDT implementation, animals were anaesthetized with the association of xylazine and ketamine. Animals were evaluated by: (i) paw measuring; and (ii) parasitological criteria. Statistics analysis were performed by specific statistics software [SPSS ${ }^{\mathrm{TM}}$ ]. The number of feasible parasites by paw was determined by a software for parasite data counting [Elida $\left.{ }^{\mathrm{TM}}\right]$. It was observed greater effectiveness for the group that used the association of PDT with LCP and miltefosine $(p<0.05)$, which had a greater reduction in parasites when compared to the other two groups, wherein the result of treatment was similar to the Negative Control group $(p<0.05)$. PDT with $L C P$, when isolated, demonstrated low effectiveness when compared to the Negative Control and gold standard group (miltefosine) $(p<0.05)$. Association of miltefosine and PDT with $L C P$ represents hopes for CL, an increasing dermatological disease among several countries.

Keywords: Cutaneous Leishmaniasis; Miltefosine; Photodynamic Therapy; Liposomal Chloro-aluminuim Phthalocyanine; Nanodrug. 


\section{SUMÁRIO}

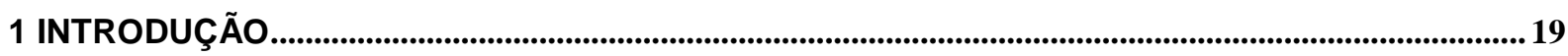

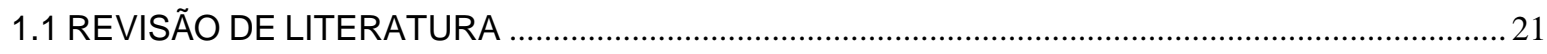

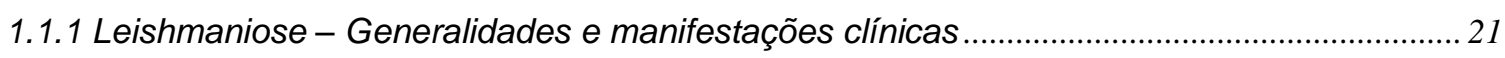

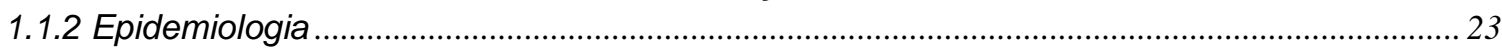

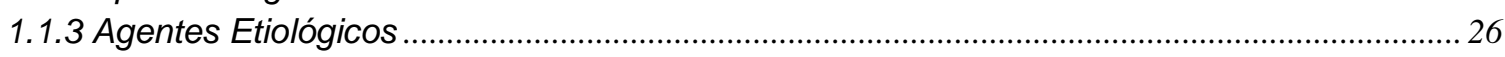

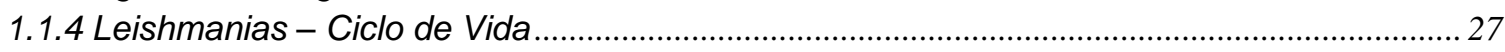

1.1.5 Transmissão

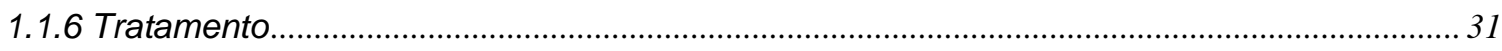

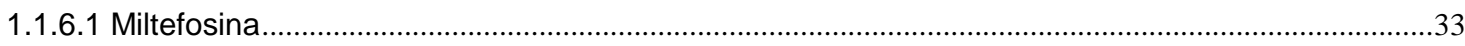

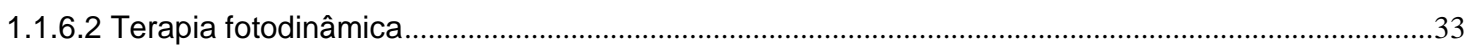

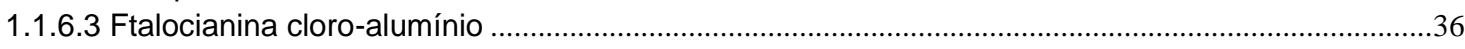

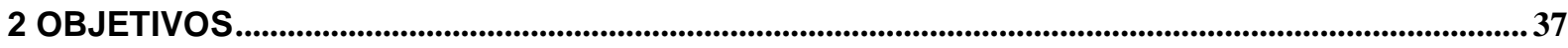

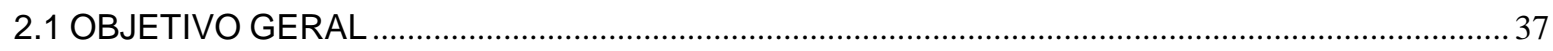

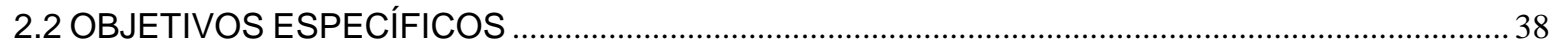

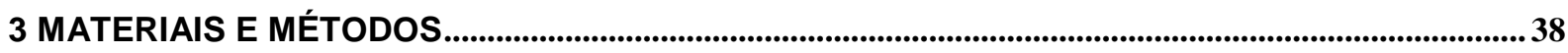

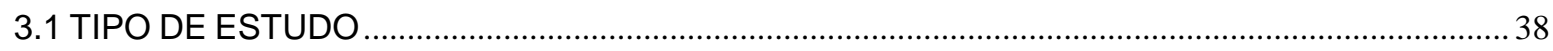

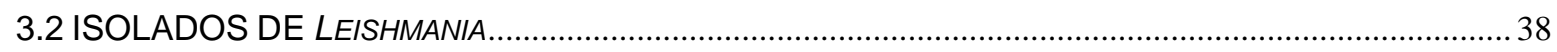

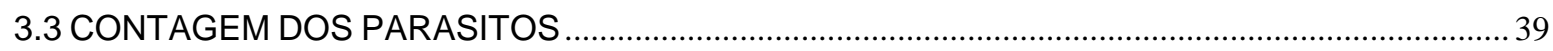

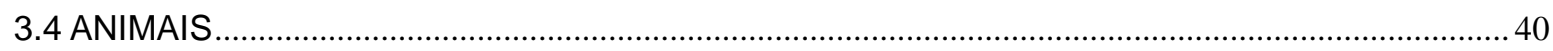

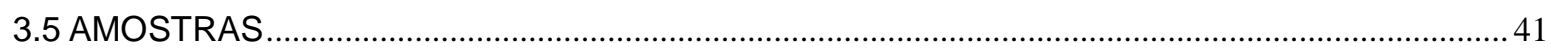

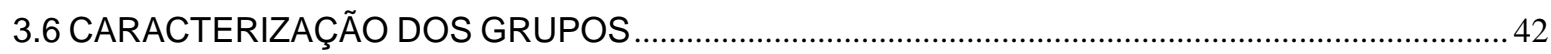

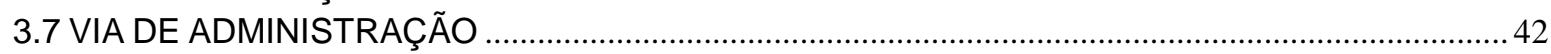

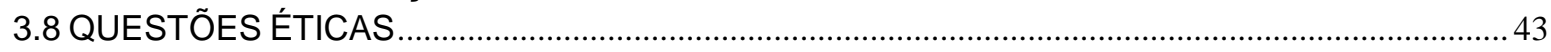

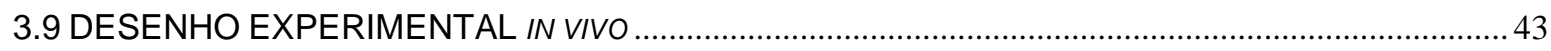

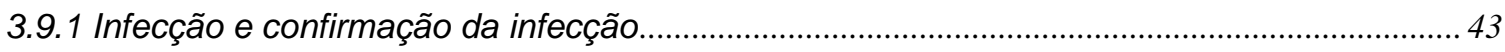

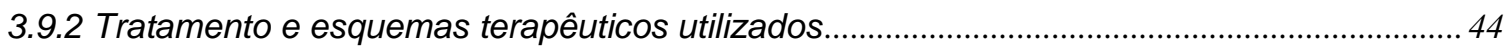

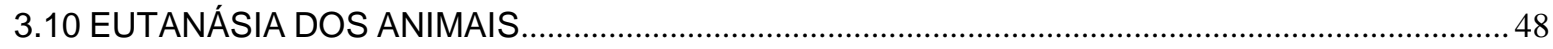

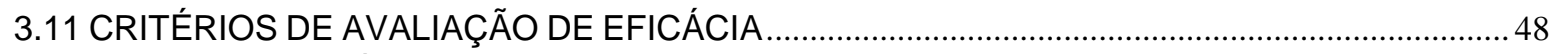

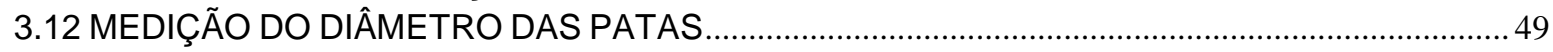

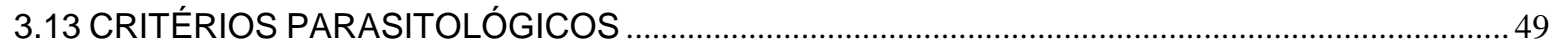

3.14 CARACTERIZAÇÃO DOS LIPOSSOMAS CONTENDO FTALOCIANINA DE CLORO-

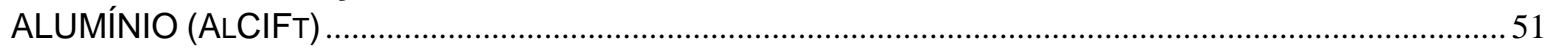

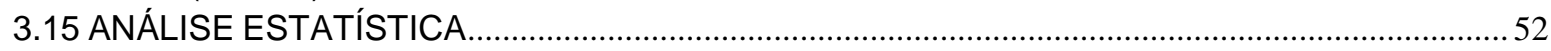

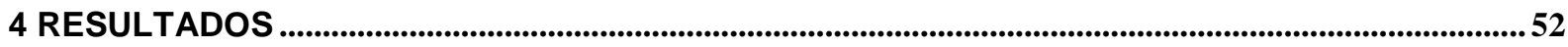

4.1 RESULTADOS DA CARACTERIZAÇÃO DOS LIPOSSOMAS CONTENDO FTALOCIANINA DE CLORO-ALUMÍNIO.

4.2 MEDIDA DAS LESÕES CUTÂNEAS (DIÂMETRO DAS PATAS) ANTES DA INFECÇÃO, 2 DIAS

APÓS A INFECÇÃO, 30 DIAS APÓS A INFECÇÃO E APÓS 20 DIAS DE TRATAMENTO. ..............54

4.3 ANÁLISE DA EFICÁCIA POR MEIO DA CONFECÇÃO DE 30 LÂMINAS DE EXTENSÃO

FIXADAS E PORTERIORMENTE CORADAS COM GIEMSA .......................................................57

4.4 RESULTADO DA ANÁLISE DA QUANTIFICAÇÃO DE PARASITA POR PATA DOS

CAMUNDONGOS

4.5 RESULTADO DA ANÁLISE DE VIABILIDADE CELULAR 


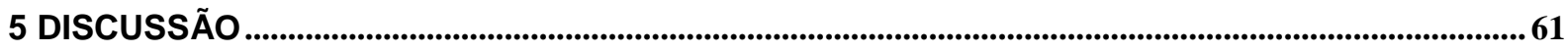

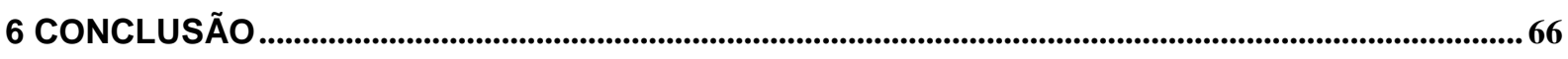

7 PERSPECTIVAS.................................................................................................................................................6

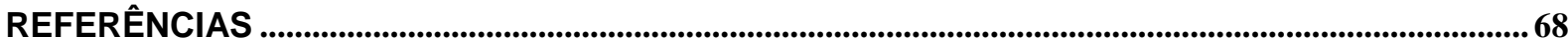

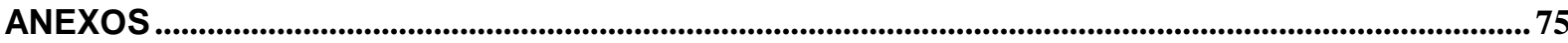

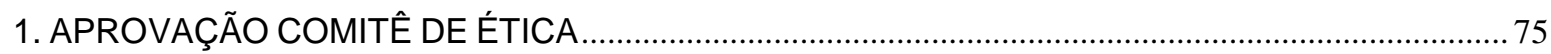

2. TESTE DE NORMALIDADE DOS DADOS DAS MEDIDAS DO PAQUÍMETRO ….............................. 76

3. ESTATÍSTICA DESCRITIVA DOS DADOS DAS MEDIDAS DO PAQUIMETRO ….............................. 77

4. ANALISE DO TESTE DE NORMALIDADE VIABILIDADE CELULAR …............................................ 78

5. ANALISE DESCRITIVA DA VIABILIDADE CELULAR ………............................................................. 79 


\section{INTRODUÇÃO}

Leishmanioses são infecções causadas por "espécies de protozoários flagelados do gênero Leishmania, que infectam a espécie humana nas regiões tropicais e subtropicais do Velho e do Novo Mundo, causando alterações no Sistema Fagocítico Mononuclear (SFM)" (DOMINGOS, 2012, p.11).

A leishmaniose cutânea é uma doença endêmica em 88 países, com incidência anual de 1 a 1,5 milhões de casos, dos quais $90 \%$ são relatados no Brasil, Afeganistão, Irã, Peru, Síria e Arábia Saudita. Como a notificação da doença é obrigatória em apenas 40 países dos 88 que apresentam incidência, segundo Desjeux (2001), há indícios de que os indicadores estejam subestimados e de que há incremento do número de casos de leishmaniose, sobretudo, devido à migração populacional, mudanças sazonais e climáticas, e desenvolvimento em áreas endêmicas. A Organização Mundial da Saúde (OMS) considera que a Leishmaniose está em expansão, com aumento de casos em todas as suas formas de manifestações que são endêmicas em todo o mundo, totalizando 350 milhões de pessoas sobe o risco de infecção (WHO, 2010).

Klaus et al. (1999) caracterizaram a leishmaniose como uma doença generalizada, com manifestações viscerais e cutâneas, sendo esta última a mais comum. Quando manifestada sob forma cutânea, há ocorrências de úlceras com bordas elevadas e localizadas, de forma geral, nas extremidades inferiores e superiores, podendo também se manifestar na cabeça, face e tronco (BARRALNETTO et al., 1997).

Garnier e Croft (2002) atribuíram a causa das manifestações clínicas da leishmaniose cutânea à espécie do parasita, ao local da inoculação, ao estado imunológico do hospedeiro, dentre outros fatores. Apesar de ser autolimitada, os indivíduos acometidos pela leishmaniose podem eventualmente desenvolver formas graves da doença mucosa, leishmaniose cutânea difusa (LCD) e disseminada.

Segundo a OMS, as drogas de escolha há mais de 60 anos para o tratamento da leishmaniose são os compostos antimoniais, sob a forma de sais pentavalentes $\mathrm{Sb}^{\mathrm{v}}$. Ainda segundo a OMS, a leishmaniose é a segunda protozoonose mais 
importante, configurando-se entre as seis enfermidades infecto-parasitárias mais importantes do mundo (WHO, 2010).

Para o tratamento contra a leishmaniose, a formulação tópica tem sido mais almejada quando comparada à terapia sistêmica em decorrência: (i) da fácil administração; (ii) dos efeitos adversos reduzidos; e (iii) do melhor custo-benefício (GARNIER e CROFT, 2002).

Mediante o apresentado, a escassez de fármacos disponíveis destinados ao tratamento da leishmaniose tem sido uma preocupação entre os membros da comunidade científica e objeto de estudo para a descoberta de alternativas eficazes para 0 tratamento desse mal. Além deste cenário, o parasita que causa a leishmaniose pode apresentar resistência aos fármacos utilizados para sua eliminação, pois estes demoram a ser excretados e o parasita desenvolve mecanismos de defesa, inibindo a eficácia do medicamento (ROJAS et al., 2006).

O desenvolvimento de terapias alternativas é uma prioridade para o tratamento da leishmaniose. Como exemplo, cita-se a terapia multimodal, ou seja, a utilização de múltiplos fármacos para o tratamento de um determinado mal em um paciente pode ser um caminho relevante para o combate à leishmaniose. Nesse sentido, a associação tópica da ftalocianina e terapia fotodinâmica (TFD) com miltefosina sistêmico pode resultar em benefícios para o combate à leishmaniose. Para tanto, o suporte das novas tecnologias tem sido essencial e nesse contexto destacam-se os estudos que envolvem a nanotecnologia como uma alternativa viável para manipular estruturas em nanoescala (FAROKHZAD e LANGER, 2009).

Os efeitos da nanotecnologia têm beneficiado a medicina como base para novas e mais efetivas drogas. Pimentel et al. (2007) afirmaram que as pesquisas têm demonstrado o elevado potencial da nanotecnologia farmacêutica para combater diversas enfermidades. Tal constatação tem ocorrido não apenas na busca de novas formas de tratamento, mas também para a prevenção e para 0 diagnóstico de várias patologias, como as parasitárias, por exemplo. Para a nanotecnologia alcançar esse destaque, pesquisadores têm investigado e elaborado técnicas inovadoras com o objetivo de desenvolver novas formas farmacêuticas de liberação controlada de fármacos capazes de manter ou ampliar a ação de agentes 
promissores utilizados no combate e controle de parasitas (CHEDGZOY et al., 2002). A nanotecnologia utilizada para o diagnóstico, tratamento, controle, e até mesmo o monitoramento dos sistemas biológicos passou a ser denominada como nanomedicina, termo apresentado pelo National Institute of Health (MOGHIMI et al, 2005).

A ftalocianina cloro-alumínio de formulação lipossomal em aplicação na terapia fotodinâmica na perspectiva de saúde coletiva tem despertado grande interesse pelo seu custo operacional inferior quando comparado com o de tratamentos tradicionalmente utilizados, pois pode ser realizada em ambiente ambulatorial, dispensando em alguns casos as internações hospitalares (LONGO, 2008).

Dentro deste contexto, a miltefosina - fármaco já consagrado como eficaz no tratamento da leishmaniose - pode ter suas doses reduzidas a partir da associação à terapia fotodinâmica (TFD) com ftalocianina cloro-alumínio de formulação lipossomal. As associações desses fármacos podem apresentar maior eficácia contra Leishmania (L.) amazonensis. A utilização da terapia fotodinâmica para o tratamento pode diminuir os efeitos colaterais causados pela terapia sistêmica para o tratamento da leishmaniose. Sendo assim, a proposta deste estudo foi realizar uma avaliação da eficácia in vivo da terapia fotodinâmica tópica com ftalocianina cloro-alumínio de formulação lipossomal para o tratamento da Leishmania (L) amazonensis, isoladamente e em associação com a terapia sistêmica com miltefosina.

\subsection{REVISÃO DE LITERATURA}

\subsubsection{Leishmaniose - Generalidades e manifestações clínicas}

A leishmaniose é um conjunto de enfermidades causadas por mais de vinte espécies de protozoários hemoflagelados do gênero Leishmania (Quadro 1), os quais são transmitidos por mais de trinta espécies de vetores fêmeas do gênero Phlebotumos e Lutzomyia (REITHINGER et al., 2007). A leishmaniose tegumentar americana (LTA), por sua vez, é uma doença infecciosa que acomete pele e mucosas. 
Quadro 1: Espécies de Leishmanias e manifestações clínicas

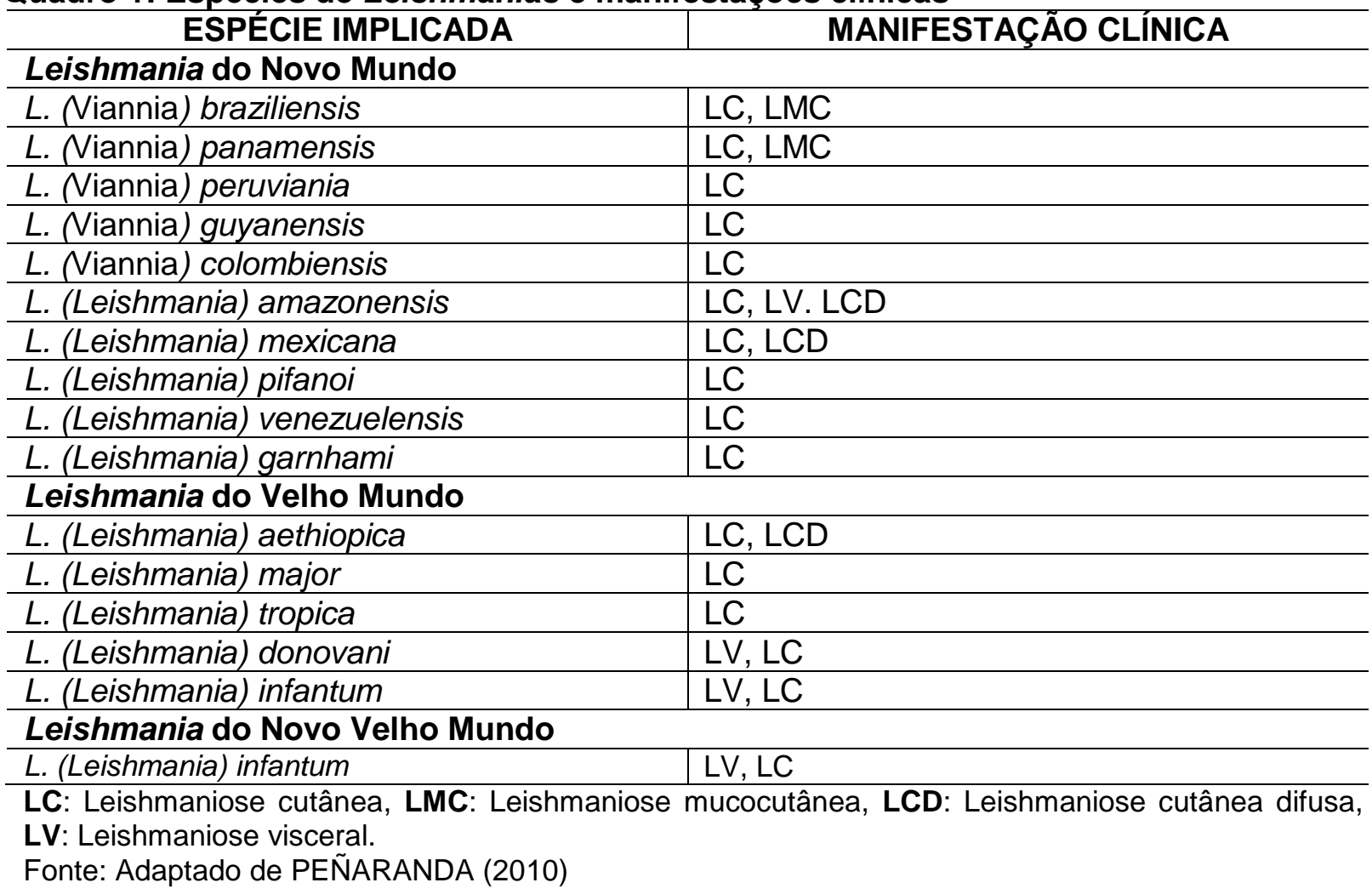

A leishmaniose produz uma gama de manifestações clínicas, como a leishmaniose cutânea (LC), caracterizada pelo desenvolvimento de lesões úlcerosas na pele, que podem ser únicas ou múltiplas (Figuras 1 e 2). Em alguns casos, são curadas espontaneamente, enquanto em outros a doença evolui deixando cicatrizes que podem ser mutilantes.

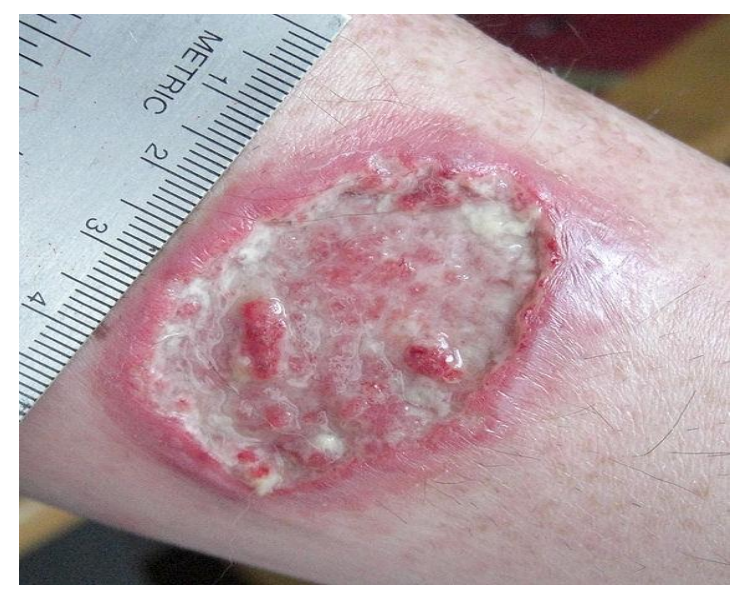

Figura 1: Leishmaniose com manifestação de lesão ulcerada única Fonte: Carneiro (2013). 


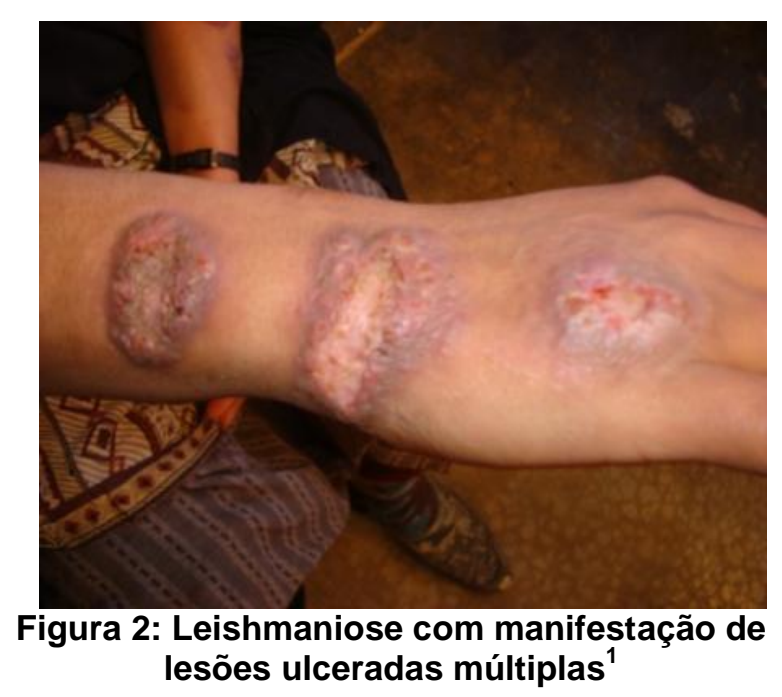

A leishmaniose mucocutânea (LMC) causa lesões destrutivas das mucosas, com lesões desfigurantes na face, em decorrência da destruição das cavidades oral, nasal e da faringe, e é causada na maioria das vezes por espécies como $L$. (V.) braziliensis. A leishmaniose cutânea difusa (LCD) se manifesta em pacientes com deficiência na reposta imune mediada por células específicas para leishmania, e se caracteriza pelo aparecimento de nódulos disseminados na pele. A leishmaniose visceral (LV), também conhecida como "kalaazar" é a forma mais severa da doença e pode ocasionar a morte dos pacientes que não são tratados. A LV caracteriza-se pela presença de esplenomegalia, hepatomegalia, perda de peso, febre, linfadenopatia e anemia. Alguns pacientes em recuperação podem desenvolver LC crônica, também conhecida como leishmaniose dérmica pós kalaazar (DESJEUX, 2004).

\subsubsection{Epidemiologia}

A leishmaniose tegumentar americana (LTA), como definiu Pereira (2012), é uma doença infecto-parasitária, causada por protozoários do gênero Leishmania, que acomete a pele e/ou mucosas, sendo transmitida pela picada de vetores do gênero Phlebotomus e Lutzomyia. Nas Américas, a LTA é considerada uma zoonose primária de mamíferos silvestres, tais como roedores, marsupiais, edentados e primatas, e o homem contrai a infecção em ocasiões de contato com áreas florestais que contêm enzootias pelas diferentes espécies de Leishmania (BASANO; CAMARGO, 2004).

\footnotetext{
${ }^{1}$ Disponível em: <http://www.emro.who.int>. Acesso em: 22 set. 2014.
} 
Segundo Basano e Camargo (2004), a Leishmaniose (tegumentar e visceral) prevalece com aproximadamente 12 milhões de casos no mundo, sendo que aproximadamente 350 milhões de pessoas estão ameaçadas de contrair a doença em 88 países, e destes, 72 são considerados países em desenvolvimento. Informações da $\mathrm{OMS}^{2}$ apontam que $90 \%$ de todos os casos de leishmaniose visceral ocorrem no Brasil, Bangladesh, Índia e Sudão, 90\% dos casos de leishmaniose cutâneo-mucosa ocorrem no Brasil, Bolívia e Peru, e que 90\% dos casos de leishmaniose cutânea correm no Brasil, Afeganistão, Irã, Arábia Saudita e Síria.

No Brasil, as leishmanioses caracterizam-se como enfermidades emergenciais em franca expansão. A portaria Ministerial no 1943 de 18 de outubro de 2001, determina a doença como um agravo de notificação compulsória em todo o território nacional. As formas tegumentares foram notificadas em 27 unidades federadas brasileiras, e casos autóctones de leishmaniose visceral americana foram notificados nas regiões Nordeste, Norte, Centro-Oeste e Sudeste (DOMINGOS, 2012).

Mais de 25 espécies da Leishmania são capazes de produzir doenças em humanos (SINGH e SIVAKUMAR, 2004). O homem, por sua vez é um hospedeiro acidental, pois a maioria das ocorrências de zoonoses está entre os animais silvestres, sobretudo roedores. Apesar de vários estudos envolvendo a imunologia da LTA, ainda há necessidade de ampliar a compreensão dos mecanismos que levam ao controle ou a persistência dos parasitas (PEREIRA, 2012). Segundo Desjeux 2001, os ciclos de transmissão da Leishmaniose adaptam-se ao peridomicílio e espalham-se para áreas não endêmicas.

No Brasil, existem no mínimo seis espécies de Leishmania responsáveis pela doença humana, e mais de 200 espécies de flebotomíneos implicados em sua transmissão (BASANO e CAMARGO, 2004). Conforme o Ministério da Saúde (2011), no Brasil, entre 1988 e 2009, a LTA representou média anual de 27.093 ocorrências, com expansão geográfica, sendo casos notificados em 19 unidades federadas em 1980 e, em 2003, registraram-se casos em todos os estados. As Tabelas 1 e 2 apresentam a distribuição de casos registrados de leishmaniose nas regiões brasileiras por ano.

\footnotetext{
${ }^{2}$ Disponível em: <http: /www.who.int/emc/disease/leish/index.html>. Acesso em: 16 jul 2014.
} 
Tabela 1: Incidência de casos de LTA (x1000.000 habitantes), por macrorregião.

\begin{tabular}{l|c|c|c}
\hline \multicolumn{1}{c|}{ Região } & $\mathbf{1 9 9 7}$ & $\mathbf{1 9 9 8}$ & $\mathbf{1 9 9 9}$ \\
\hline Norte & 97,9 & 30,0 & 92,3 \\
\hline Nordeste & 26,2 & 18,4 & 19,0 \\
\hline Sudeste & 3,4 & 4,7 & 4,8 \\
\hline Sul & 1,8 & 1,9 & 1,9 \\
\hline Centro Oeste & 44,2 & 27,1 & 50,4 \\
\hline
\end{tabular}

Fonte: Ministério da Saúde (BRASIL, 2000).

Tabela 2: Valores absolutos de LTA, por macrorregião

\begin{tabular}{l|c|c|c|c|c|c|c}
\hline Região & $\mathbf{1 9 9 7}$ & $\mathbf{1 9 9 8}$ & $\mathbf{1 9 9 9}$ & $\mathbf{2 0 0 0}$ & $\mathbf{2 0 0 1}$ & $\mathbf{2 0 0 2}$ & $\mathbf{2 0 0 3}$ \\
\hline Norte & 11058 & 6078 & 11201 & 11140 & 12369 & 12489 & 14200 \\
\hline Nordeste & 11868 & 8455 & 9112 & 13078 & 15057 & 11548 & 8005 \\
\hline Sudeste & 2294 & 2945 & 3983 & 2938 & 2041 & 3514 & 3472 \\
\hline Sul & 430 & 455 & 460 & 853 & 635 & 1053 & 951 \\
\hline Centro-Oeste & 4640 & 2981 & 6384 & 4605 & 4962 & 5440 & 4635 \\
\hline
\end{tabular}

Fonte: Ministério da Saúde. (BRASIL, 2004)

As três principais espécies de Leishmania notificadas no Brasil e que causam LTA são pertencentes a dois subgêneros: (i) Viannia, representado pelas espécies $L$. (V.) braziliensis, mais prevalente, e L. (V.) guyanensis, associadas com lesões cutâneas localizadas, disseminadas ou raramente mucocutâneas; e (ii) Leishmania, representado pela espécie $L$. (L.) amazonensis, associada, ainda conforme Pereira (2012), com o desenvolvimento de lesões cutâneas localizadas ou com a forma difusa de LTA.

No estudo de Silveira (2001), foram descritos os três perfis da leishmaniose com registros mais presentes nas regiões brasileiras: (i) leishmaniose tegumentar puramente silvestre, com surtos epidêmicos associados ao desmatamento, sobretudo na Amazônia; (ii) leishmaniose tegumentar silvestre modificada, com surtos epidêmicos sazonais, normalmente em regiões com poucos focos residuais de mata primária; e (iii) leishmaniose tegumentar periurbana, com forma endemoepidêmica, endo ou peridomiciliar, em áreas de colonização antiga e que contenham animais domesticados e que sejam reservatórios.

Não só no Brasil, mas como em todos os outros países do chamando Novo Mundo, a LTA representa um sério problema de saúde pública e sua importância está em sua alta incidência, ampla distribuição geográfica, e em sua possibilidade de assumir outras formas que podem determinar lesões destrutivas, desfigurantes e 
incapacitantes, com impactos no campo psicossocial das pessoas (GONTIJO; CARVALHO, 2003).

\subsubsection{Agentes Etiológicos}

Historicamente, a primeira ocorrência da leishmaniose no Brasil foi identificada em 1885, na Bahia, por Alexandre Cerqueira. Em 1911, Gaspar Vianna propôs a denominação Leishmania braziliensis para o agente específico da LTA no Brasil (VIANNA, 1912).

O Quadro 2 apresenta a descrição das seis espécies principais de Leishmania identificadas no Brasil envolvidas na LTA, que fazem parte dos subgêneros Leishmania e Viannia (BRASIL, 2010).

\section{Quadro 2: Principais espécies de Leishmania no Brasil.}

\begin{tabular}{|c|c|}
\hline $\begin{array}{l}\text { Leishmania } \\
\text { (Viannia) } \\
\text { braziliensis }\end{array}$ & $\begin{array}{l}\text { - Transmitida por diferentes espécies de flebotomíneos como Lutzomyia } \\
\text { whitmani, Lu. Wellcomei e Lu. intermedia. } \\
\text { - Espécie mais prevalente no homem. } \\
\text { - Pode causar lesões cutâneas e mucosas. } \\
\text { - Encontrada em zonas endêmicas do País - norte até o sul. } \\
\text { - Geralmente associada a animais domésticos. }\end{array}$ \\
\hline $\begin{array}{l}\text { Leishmania (V.) } \\
\text { guyanensis }\end{array}$ & $\begin{array}{l}\text { - Principais espécies envolvidas são a Lu. umbratilis, Lu. anduzei e Lu. } \\
\text { whitmani. } \\
\text { - Causa lesões cutâneas. } \\
\text { - Maior ocorrência: norte Rio Amazonas. Áreas de colonização recente. } \\
\text { - Associada a desdentados e marsupiais. }\end{array}$ \\
\hline $\begin{array}{l}\text { Leishmania (V.) } \\
\text { naiffi }\end{array}$ & $\begin{array}{l}\text { - Principais vetores: Lu. squamiventris, Lu. paraensis e Lu. ayrozai. } \\
\text { - Causa LTA de evolução benigna. } \\
\text { - Ocorre no Pará e Amazonas. } \\
\text { - O tatu é o reservatório natural. }\end{array}$ \\
\hline $\begin{array}{l}\text { Leishmania (V.) } \\
\text { shawi }\end{array}$ & $\begin{array}{l}\text { - Vetor: Lu.whitmani. } \\
\text { - Casos esporádicos no Amazonas e Pará. } \\
\text { - Reservatórios são animais silvestres (macacos, preguiças e } \\
\text { procinídeos). }\end{array}$ \\
\hline $\begin{array}{l}\text { Leishmania (V.) } \\
\text { lainsoni }\end{array}$ & $\begin{array}{l}\text { - Vetor: Lu. ubiquitalis. } \\
\text { - Registrada apenas na Amazônia. } \\
\text { - Paca como principal reservatório. }\end{array}$ \\
\hline $\begin{array}{l}\text { Leishmania } \\
\text { (Leishmania) } \\
\text { amazonensis }\end{array}$ & $\begin{array}{l}\text { - Principais vetores: Lu. flaviscutellata e Lu. olmeca. } \\
\text { - Agente etiológico da LTA, incluindo a forma anérgica ou leishmaniose } \\
\text { cutânea difusa. } \\
\text { - Os reservatórios são roedores e marsupiais. }\end{array}$ \\
\hline
\end{tabular}

Fonte: Brasil, Ministério da Saúde (2010). Adaptado pelo Autor.

O Quadro 3 apresenta uma sistematização das espécies de Leishmania dos subgêneros Leishmania e Viannia. 
Quadro 3: Principais espécies de Leishmania no Brasil.

\begin{tabular}{|c|c|c|}
\hline Seq. & Subgênero Leishmania & Subgênero Viannia \\
\hline 01 & L. (Leishmania) donovani ${ }^{* * *}$ & L. (Viannia) braziliensis \\
\hline 02 & L. (L.) infantum ${ }^{\star \star *}$ & L. (V.) guyanensis* \\
\hline 03 & L. (L.) chagasi ${ }^{* \star *}$ & L. (V.) panamensis \\
\hline 04 & L. (L.) archibaldi & L. (V.) peruaviana \\
\hline 05 & L. (L.) tropica** & L. (L.) lainsoni* \\
\hline 06 & L. (L.) aethiopica** & L. (L.) naiffi* \\
\hline 07 & L. (L.) major ${ }^{\star \star}$ & L. (L.) shawi* \\
\hline 08 & L. (L.) gerbili & L. (L.) colombiensis* \\
\hline 09 & L. (L.) mexicana & L. (L.) Lindemberg \\
\hline 10 & L. (L.) amazonenses & \\
\hline 11 & L. (L.) venezuelensis & \\
\hline 12 & L. (L.) enriettii & \\
\hline 13 & L. (L.) aristidesi & \\
\hline 14 & L. (L.) pifanoi & \\
\hline
\end{tabular}

Fonte: Lainson e Shaw (1987). Adaptado pelo Autor.

$\left({ }^{*}\right)$ Determinantes da Leishmaniose Tegumentar Americana no Brasil; $\left({ }^{* *}\right)$ Determinantes da Leishmaniose no Velho Mundo (Europa); $\left.{ }^{* * *}\right)$ Determinantes da Leishmaniose Visceral.

Os flebotomíneos ${ }^{3}$ representam o grupo de insetos hematófagos que transmitem leishmaniose. Como características, não ultrapassam $0,5 \mathrm{~cm}$ de comprimento, com pernas longas e finas, e corpo piloso. O voo destes insetos é saltitante e eles mantêm as asas eretas, mesmo em repouso. Possuem a cor parda e as fêmeas estão adaptadas a picar a pele de vertebrados e sugar sangue (BASANO e CAMARGO, 2004). Popularmente, são conhecidos como mosquito palha, asa dura, asa branca, tatuquira, birigui, cangalha, cangalhinha, ligeirinho, péla-égua, arrupiado (sic) (RABÊLO, 1999). No que se refere ao gênero Lutzomyia, responsável pela transmissão da leishmaniose nas Américas, existem aproximadamente 350 espécies catalogadas, sendo que destas, 200 são identificadas na bacia amazônica (RABÊLO, 1999).

\subsubsection{Leishmanias - Ciclo de Vida}

Conforme Ramos et al. (2011), o ciclo de vida das leishmanias inclui uma fase extracelular, que ocorre na parte interior do trato digestivo, e outra fase intracelular, que ocorre dentro de macrófagos dos mamíferos que têm sua imunidade reduzidas, pois são responsáveis pela fagocitose de microrganismos e pela liberação de interleucinas no processo inflamatório (OTA et al., 2008). Em função do processo de

\footnotetext{
${ }^{3}$ Ordem Díptera; Família Psychodidae; Sub-Família Phlebotominae.
} 
reversão da maquinaria de ataque, o patógeno resiste à atividade de fagocitose (BALLAND et al., 1996).

As formas infectantes das leishmanias são denominadas metacíclicas, e as formas não infectantes são conhecidas como procíclicas, e ambas podem ser encontradas em culturas de células livres. As formas não infectantes são mais abundantes na fase estacionária, quando uma variedade de genes apresentam diferentes padrões, e alguns codificam fatores virulentos (RAMOS et al., 2011).

A Figura 3 representa o ciclo de vida dos parasitas do gênero Leishmania, que são transferidos para o hospedeiro no estado de promastigota forma alongada com flagelo externo, onde são fagocitadas e se diferenciam para amastigotas arredondada, sem flagelo -, proliferando-se e estabilizando a infecção (GOTO e LINDOSO, 2010).

Segundo Carvalho (2011), a invasão do patógeno não causa a doença em si, mas é necessária para estabelecer a infecção, sendo um pré-requisito para a virulência. $\mathrm{O}$ autor agrega que dois mecanismos de virulência das leishmanias têm sido propostos, por envolverem dois grupos diferentes de moléculas do parasita, sendo que um deles é constituído principalmente na superfície celular e em substâncias secretadas, e o outro inclui moléculas intercelulares, denominadas patoantígenos. O primeiro grupo é constituído por determinantes invasivos que protegem os parasitas e evitam que as células do hospedeiro sofram lise prematuramente, contribuindo para a manutenção da infecção pelas amastigotas por conta do crescimento baixo em vacúolos parasitóforos dos macrófagos do hospedeiro.

Nesse sentido, as manifestações clínicas são decorrentes do segundo grupo que causa imunopatologia da doença. Tais moléculas são altamente conservadas por proteínas citoplasmáticas, nas quais são encontradas por possuírem epíteto leishmanias único, imunologicamente ativo na leishmaniose. Os parasitas passam por citólise periódica durante a infecção natural, feita a exposição dos antígenos intracelulares ao sistema imune do hospedeiro (CHANG et al., 2003). 


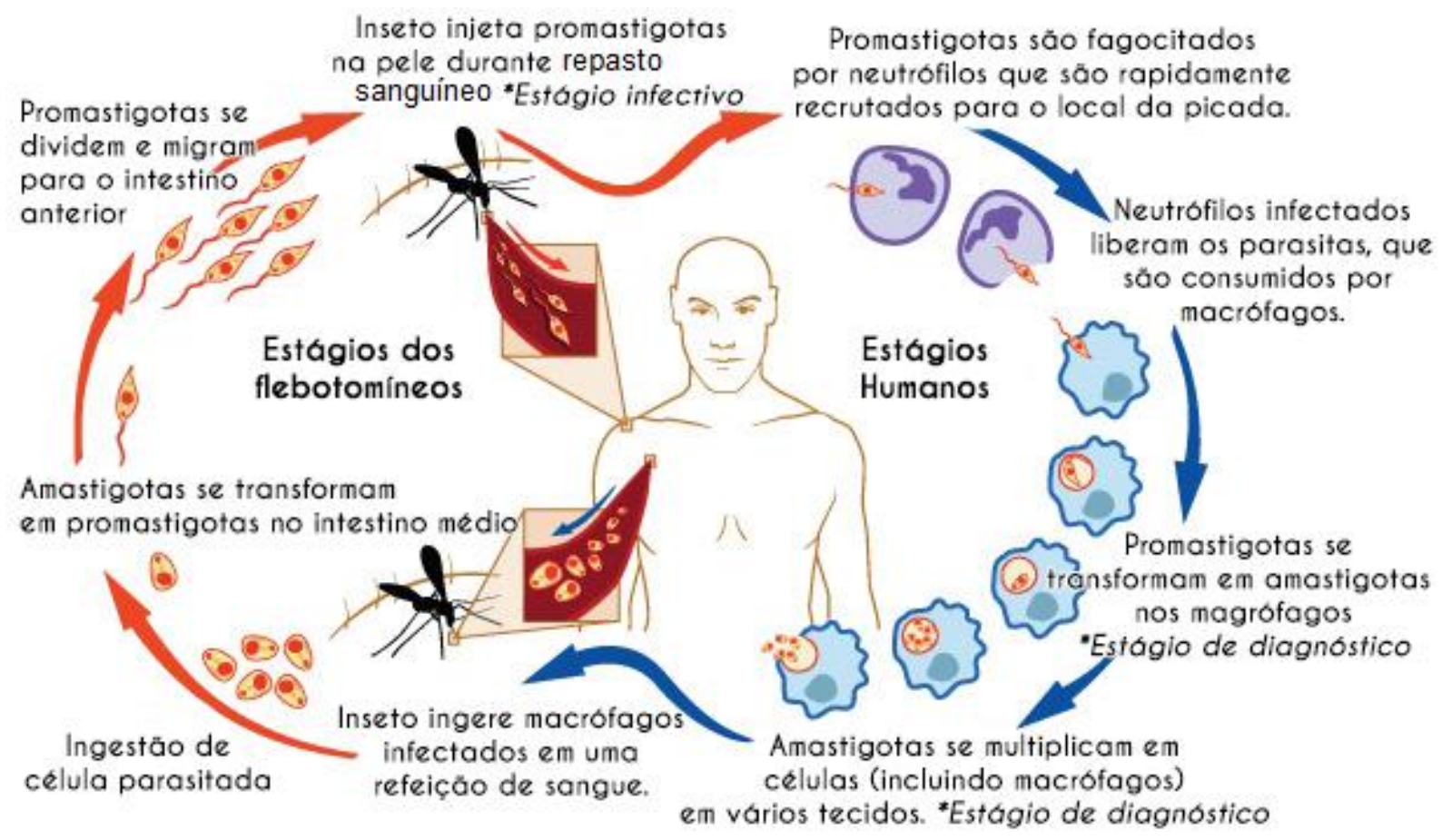

Figura 3: Leishmania e seus estágios no organismo humano Adaptada de: National Institute of Allergy and Infectious Diseases ${ }^{4}$

De forma sumária, a Figura 3 apresenta os estágios humanos e do parasita do gênero Leishmania. Os vetores, em seu estágio não infectante, ingerem macrófagos quando sugam sangue de reservatórios infectados, momento em que há ingestão de células parasitadas. As duas formas principais encontradas no ciclo do parasito são a flagelada promastigota e a amastigota. A primeira é encontrada no tubo digestivo e na saliva do inseto vetor, o flebotomínio, um díptero, e pode ser mantida em meio de cultura artificial. A forma amastigota, após ser inoculada no mamífero pelo vetor hematófago, desenvolve-se dentro do vacúolo fagolisossômico dos macrófagos nos tecidos hospedeiros vertebrados (homem e outros mamíferos) (DESJEUX, 2001).

As formas amastigotas se dividem e migram para o intestino anterior e médio do vetor. Quando o vetor infectado injeta formas promastigotas na pele durante a picada, ao se alimentar com sangue, inicia-se o estágio humano. As promastigotas são fagocitadas por neutrófilos que são rapidamente recrutados para o local da picada. Os neutrófilos infectados libertam os parasitas, que então são consumidos por macrófagos.

\footnotetext{
${ }^{4}$ Disponível em: <http://www.niaid.nih.gov/topics/leishmaniasis/pages/lifecycle.aspx>. Acesso em: 06 nov. 2013.
} 


\subsubsection{Transmissão}

A leishmaniose é transmitida por fêmeas infectadas dos dípteros da subfamília Phlebotominae, constituintes do gênero Lutzomyia (para os casos do Novo Mundo) e Phlebotomus (para os casos do Velho Mundo). O inseto pode voar centenas de metros e sua picada costuma ser dolorosa (CARNEIRO, 2013). As Figuras 4 e 5 apresentam, respectivamente, exemplos de Lutzomyia e Phlebotomus.

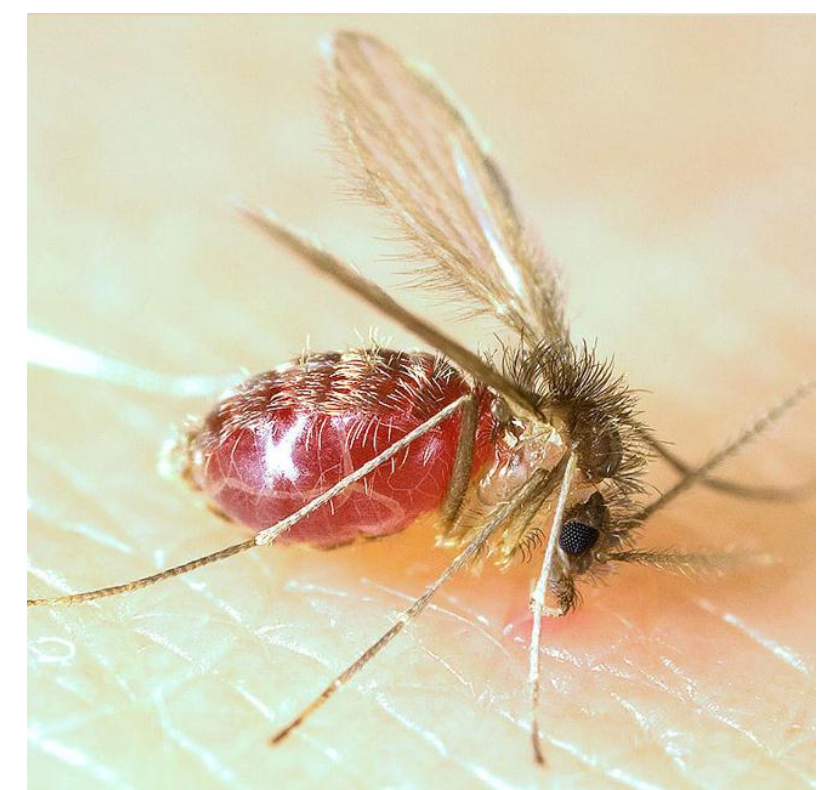

Figura 4: Mosquito do gênero Lutzomyia após repasto sanguíneo

Fonte: Carneiro (2013).

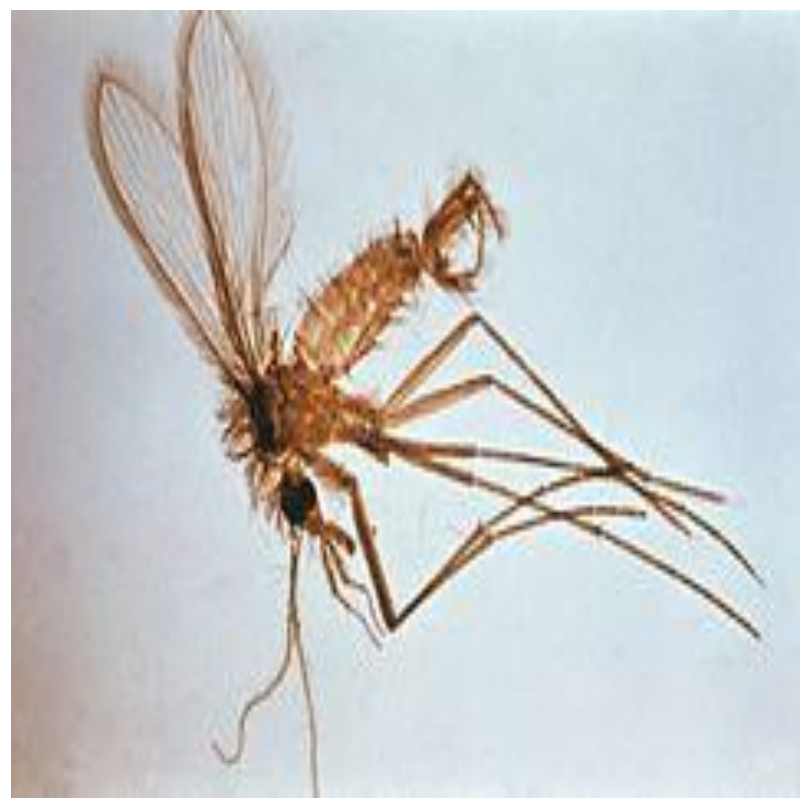

Figura 5: Mosquito do gênero Phlebotomus. 
Conforme Basano e Camargo (2004), a LTA está distribuída em todo o Brasil. O principal hospedeiro silvestre é o roedor Proechimys sp. (rato-soiá), além de outros roedores, tais como Oryzomys sp., Neacomys sp., Nectomys sp e Dasyprocta sp.; os marsupiais Metachirus sp., Philander sp., Didelphis sp. e Marmosa sp.; e a raposa Cerdocyon thous. Segundo Carneiro (2013), há outros pequenos animais silvestres no ciclo da doença, como macacos, tatus e preguiças. O vetor Lutzomyia flaviscutellata tem hábito noturno e pouco antropofílico, sendo responsável pela leishmaniose cutânea, cutâneo-mucosa, e cutânea difusa anérgica. Esta última forma ainda é pouco conhecida e não responde favoravelmente ao tratamento (BASANO e CAMARGO, 2004).

\subsubsection{Tratamento}

Segundo Frezard et al. (2009), os compostos antimoniais pentavalentes (Sbv), como o antimoniato de meglumina (Glucantime®) e estibogluconato de sódio (Pentostam ${ }^{\circledR}$ ) têm sido utilizados há mais de sessenta anos como medicamentos de primeira linha. Não se conhece a estrutura exata destas moléculas e o mecanismo de ação ainda não foi bem definido. Há indícios de que os $\mathrm{Sb}^{v}$ se comportam como um pró-fármaco que ao ingressar na célula é reduzido à sua forma trivalente $\mathrm{Sb}^{\mathrm{III}}$, a qual é tóxica para a Leishmania, além de inibir a síntese de DNA, RNA e proteínas do parasita e induzir a fragmentação de $A D N$ e a expressão de fosfatidilserina (SERENO et al., 2001).

Os $\mathrm{Sb}^{v}$ são utilizados para o tratamento de todas as formas clínicas da leishmaniose. Uma meta-análise de 23 estudos mostrou que $76 \%$ dos pacientes com LC no Novo Mundo respondem à terapia com Sbv ${ }^{v}$, sendo a $L$. (V.) braziliensis a espécie que prevalece, com $87,5 \%$ dos casos (TUON et al., 2008).

Segundo Tuon et al. (2008), foram observadas diferenças na resposta ao tratamento com antimônios pentavalentes segundo a região estudada, como no caso de 310 pacientes no Brasil que apresentaram uma média de cura de $71,3 \%$, enquanto que em 449 dos pacientes na Colômbia, foi de 91,0\%.

A dose de $\mathrm{Sb}^{v}$ administrada aos pacientes tem aumentado muito. Em meados dos anos 70, a dose total para um paciente adulto de $65 \mathrm{~kg}$ era de $4,25 \mathrm{~g}$ de 
antimônio ( 6,5mg/Kg $\times 10$ dias). Em 1984, a OMS aumentou a dose e recomendou que fosse administrada a um paciente de $65 \mathrm{Kg}$ o total de $26 \mathrm{~g}(20 \mathrm{Sb} / \mathrm{Kg}$ por dia durante 20 dias), critério que ainda se mantém vigente. As maiores desvantagens que se apresentam neste tratamento são a ocorrência de cepas resistentes aos antimoniais, como o caso de Bihar na Índia, que em algumas regiões ultrapassa $50 \%$ (SUNDAR, 2001), e os numerosos efeitos colaterais, como: dores no local de aplicação durante a injeção intramuscular, vômito, náuseas, elevação de transaminases, mialgias, artralgias, nefrotoxidade, hepatotoxidade, cefaleia, diarreia, alterações eletrocardiográficas, falhas cardíacas e morte associada à fibrilação ventricular (SAMPAIO et al., 1997).

Peñaranda (2010) considera o tratamento baseado no uso de antimônio pentavalente administrado parenteralmente em doses de $20 \mathrm{mgSb} / \mathrm{Kg}$ durante 20 dias para o tratamento da LC e 28 dias para LCM e LV. Agrega que quando há falha terapêutica, administra-se novamente $20 \mathrm{mgSb} / \mathrm{Kg}$ por mais 20 dias. A possibilidade de a falha estar associada a diferenças na sensibilidade ao antimônio pentavalente dos parasitos foi investigada utilizando-se, principalmente, análise de sensibilidade in vitro (RODRIGUES, 2012). Como os resultados ainda são contraditórios, Rodrigues (2012) avaliou a sensibilidade in vivo de Leishmania (Viannia) braziliensis isoladas de pacientes portadores de LC ao antimoniato de meglumina, bem como a atividade da combinação de uma baixa dose de $\mathrm{Sb}^{\mathrm{V}}$, sendo que o resultado, para a cepa M2903 mostrou-se eficaz na redução do tamanho da lesão nos animais, mas não na redução da carga parasitária (RODRIGUES, 2012).

Como tratamento de segunda opção, utiliza-se o isotionato de pentamidina (Pentacarinat $\AA^{\circledR}$ ) em dose de $4 \mathrm{mg} / \mathrm{Kg} / \mathrm{dia}$. A alta toxidade destas anti-leishmaniais são obstáculos no tratamento da doença, podendo em alguns casos ocasionar sua interrupção (OLIVEIRA et al., 2011). Em tratamentos de maior complexidade, aplicase a anfotericina $B$ (Fungizone ${ }^{\circledR}$ ), que é um antibiótico polienomacrólido produzido por Streptomyces nodosus, cujo mecanismo de ação está relacionado com a afinidade do medicamento pelos esteróis que causam a permeabilidade da membrana celular, pela formação de poros aquosos (BRAJTBURG e BOLARD, 1996). 
A anfotericina B apresenta uma excelente atividade leishmanicida e tem sido de grande utilidade para o tratamento de LMC, LCD e LV (RODRIGUEZ et al., 1995). Os maiores limitantes da anfotericna B são o custo, a hospitalização do paciente para tratamento e os efeitos colaterais, uma vez que pode ser cardiotóxico e nefrotóxico (CLEMENTS e PEACOCK, 1990).

\subsubsection{Miltefosina}

Miltefosina (Impavido®), um alquilfosfolipídio desenvolvido originalmente contra o câncer, foi incluído ao tratamento da leishmaniose e constitui a primeira opção em caso de tratamento oral. Estudos comprovam sua atividade antiprotozoária em Trypanosoma cruzi, Trypanosoma brucei, Entamoeba hystolitica e Leishmania, exibindo um considerável potencial microbicida (SEIFERT et al, 2001). Paris et al. (2004) consideram que seu mecanismo de ação está relacionado com a interferência em vias de sinalização celular, ativação de macrófagos citotóxicos, alterações na membrana lipídica e apoptose. Já Perez-Victoria et al. (2006) falam sobre os efeitos teratogênicos e reações adversas resultantes da miltefosina, e sugerem que o desenvolvimento de cepas resistentes pode ser decorrente da larga vida média do composto no organismo humano.

Outros estudos apresentam resultados de eficácia da miltefosina para 0 tratamento contra a leishmaniose. Soto et al. (2008) utilizaram miltefosina para o tratamento de leishmaniose tegumentar, em estudos envolvendo humanos na Bolívia, e obtiveram cerca de $88 \%$ de eficácia no tratamento de lesões cutâneas. Em outros estudos, Vélez et al. (2010), Machado et al. (2010), e Chrusciak-Talhari et al. (2011), obtiveram percentuais de cura de, respectivamente, 69,8\%, 88,2\% e 71,4\%.

\subsubsection{Terapia fotodinâmica}

A terapia fotodinâmica (TFD) é uma modalidade de tratamento que utiliza uma droga fotosensibilizadora ativada durante a geração de luz laser e é efetiva para aplicações oncológicas e nano-oncológicas (FISHER et al., 1995). O fotosensibilizador é um composto químico que, ao absorver radiação em um determinado comprimento de onda, é capaz de induzir uma alteração química ou física em um organismo (PEÑARANDA, 2010). Assim, a TFD é baseada na fotooxidação de matéria biológica. Isso requer a presença de sensibilizadores no tecido 
a ser tratado. Embora tais sensibilizadores possam naturalmente ocorrer nas células, no caso da TFD, são introduzidos no organismo no primeiro passo do tratamento. Em seguida, os sensibilizadores são expostos à luz com comprimento de onda adequado para sua absorção. Através de vários caminhos foto-físicos, produtos oxigenados nocivos surgem, além de eventuais resultados de destruição da pele (HENDERSON; DOUGHERTY, 1992). Escobar et al. (2006) corroboram com esta definição quando consideram que a TFD é um procedimento que envolve o uso de agentes fotossensíveis, seguido de iluminação seletiva na lesão alvo, com luz visível, que produz alta reação de oxigênio.

A TFD pode ser atrativa pelo baixo custo e pela redução de efeitos colaterais, e se constitui em uma opção que pode ser combinada com outros medicamentos, embora ainda exista carência de estudos aprofundados que determinem seu impacto para o tratamento contra leishmaniose (AMEEN, 2010). Ainda no que se refere aos custos, Hopper et al. (2004) afirmam que dentre as vantagens da TFD, como os fatores biológicos, está o custo operacional inferior aos tratamentos tradicionais. Entretanto, ressalta-se que, geralmente, o valor do equipamento de laser é muito caro.

Segundo Longo (2008), a grande vantagem na utilização da TFD é diminuição dos efeitos colaterais observados pós-tratamento em comparação com as outras modalidades terapêuticas.

\subsection{Mecanismos de ação fotoquímicos}

Sobre os mecanismos de ação fotoquímicos, Longo (2008) afirmou que o princípio básico da TFD é a geração de agentes citotóxicos por meio de interações dinâmicas entre fármacos fotossensibilizadores (FS) excitados por luz em comprimentos de onda específicos. Assim, estes fármacos são ativados com a absorção de fótons pelos FS, ocorrendo situações de grande instabilidade química nestas moléculas, mudando ainda o padrão de organização eletrônica normal. A molécula com algum grau de excitação eletrônica tende a retornar ao seu estado fundamental, energicamente favorável. Ainda conforme o autor, o retorno da molécula ao estado estável é decorrente da emissão de energia na mesma intensidade da energia de absorção de fóton pelo fármaco FS. A Figura 6 apresenta 
o esquema de funcionamento da reação fotoquímica presente na TFD, descrevendo a produção de radicais livres após excitação do FS com irradiação a laser.

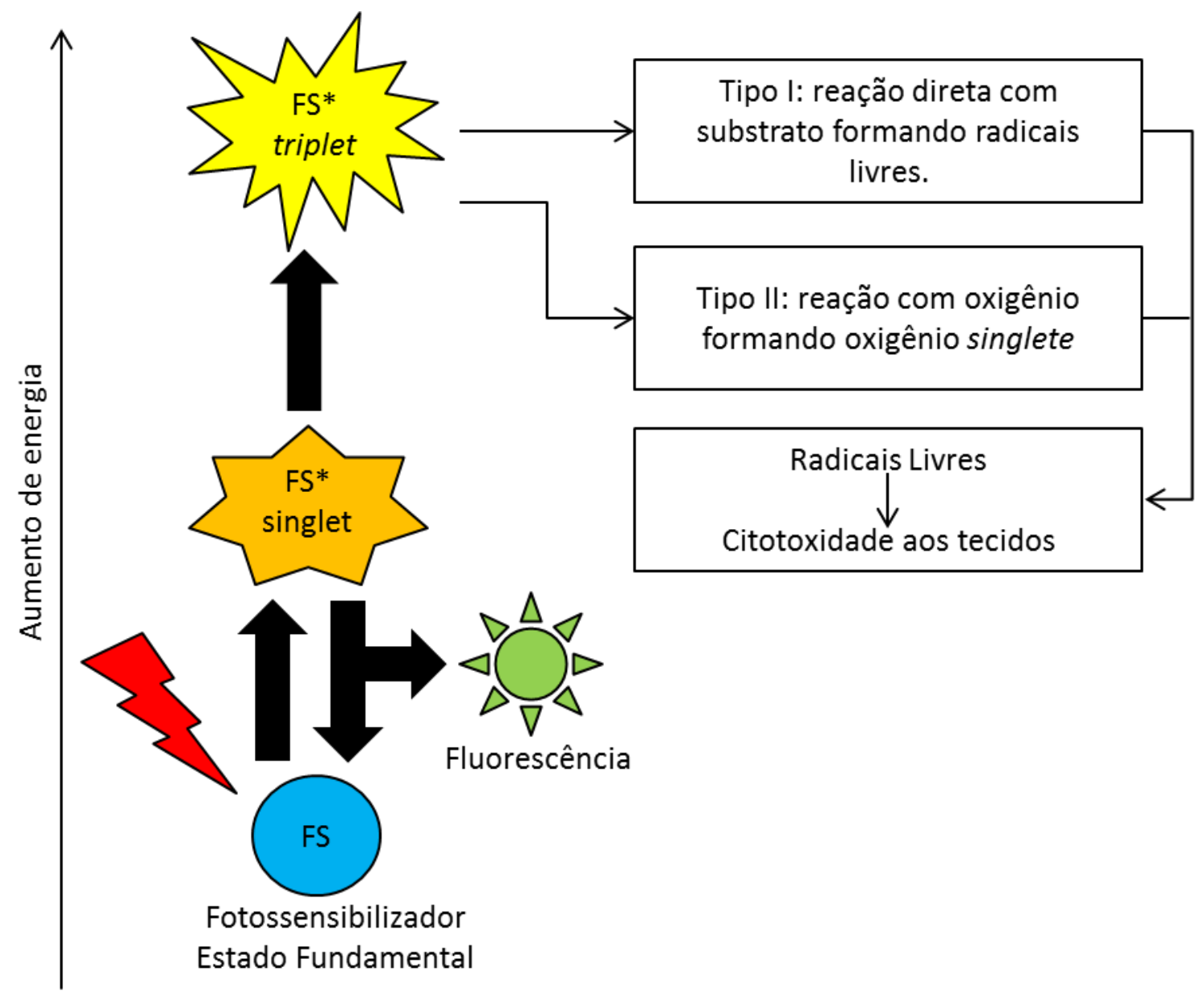

Figura 6: Desenho do funcionamento da reação fotoquímica presente na TFD, onde está descrita a produção de radicais livres após a excitação do FS com irradiação a laser. Fonte: Longo (2008, p.8).

\subsection{Fármacos Fotossensibilizadores}

Os fotossensibilizadores (FS) transferem energia luminosa para provocar reações que resultam em formação de espécies químicas altamente reativas que destroem as células-alvo, configurando-se como um dos principais elementos na execução de TFD. Os FS estão classificados em três gerações: (i) primeira geração, os desenvolvidos no final dos anos setenta; (ii) segunda geração, desenvolvidos na década de noventa; e (iii) terceira geração, refere-se às associações terapêuticas aos FS (DOUGHERTY et al., 1998). Como apresenta o Quadro 4, outros autores classificam famílias de FS conforme semelhanças químicas entre os fármacos (ALISSON et al., 2004). 
Quadro 4: Classificação dos FS por famílias

\begin{tabular}{l|l|l}
\hline Família & Precursor Químico & Nome Comercial \\
\hline \multirow{2}{*}{ Porfirinas } & Derivados de hematoprofirina & Photofrin® \\
\cline { 2 - 3 } & Ácido aminolevulínico (ALA) & Levulan® \\
\cline { 2 - 3 } & Vertipotfirina & Visudyne® \\
\hline Clorinas & Temoprofina & Foscan® \\
\cline { 2 - 3 } & Talaprofin & LS11® \\
\cline { 2 - 3 } & Photochlor (HPPH) & Photochlor $\AA$ \\
\hline Ftalocianina & Alumínio-Sulfonada-Ftalocianina & Photosesns $\AA$ \\
\hline
\end{tabular}

Fonte: Alisson et al., 2004.

A definição pelo FS ideal para execução de TFD varia em função da toxidade e carcinogenicidade dos fármacos, seletividade pelas células-alvo, possíveis efeitos adversos ocasionados pela exposição à luz branca, via de administração, custos, capacidade de eliminação das drogas, e comprimento de onda para ativação e eficácia clínica (LONGO, 2008).

\subsubsection{Ftalocianina cloro-alumínio}

A ftalocianina cloro-alumínio tem sido associada às terapias para tratamentos dermatológicos e parasitários, como o estudo de Bastos et al. (2013), que apresenta a análise de sua ação com a quimioterapia fotodinâmica antimicrobiana. Outros estudos e ensaios pré-clínicos demonstraram resultados promissores para a sua aplicação na TFD. Dentre suas vantagens, as ftalocianinas são ativadas por luz em comprimento de onda elevado (650-750 nm), o que permite maior penetração. Outro fator é sua hidrofobicidade que a incorpora a sistemas de liberação de drogas especificas para que possam circular por meio do plasma sanguíneo (ALISSON et al., 2004).

Segundo Oliveira et al. (2006), a associação de ftalocianinas a lipossomas permite maior captação por células tumorais. A presença de lipídio na parede lipossomal amplia a captação dos fármacos pelos tecidos tumorais, pelo aumento de receptores de membrana, e essa afinidade química permite maior captação de FS pelas células neoplásicas.

A microencapsulação é uma técnica que tem sido amplamente adotada por indústrias farmacêuticas, alimentícias, têxteis e cosméticas, em decorrência de sua 
característica de proteção de substâncias lábeis e voláteis, controle da liberação do fármaco, apoiando, desta forma, a melhoria na biodisponibilidade, redução de doses terapêuticas e toxidade. Lasic (1998) apontou a aplicabilidade da microencapsulação como modelo para técnicas mais sofisticadas, em escala manométrica, permitindo o desenvolvimento de nanopartículas. Com a descoberta dos lipossomas na década de 60 , a quantidade de tecnologias para o desenvolvimento da nanotecnologia farmacêutica aumentou com sistemas lipídicos para vetorização de fármacos, permitindo posteriormente o desenvolvimento de nanossistemas, como lipossomas e nanopartículas e microssistemas, como micropartículas, emulsões múltiplas e microemulsões (SILVA, 2004).

Lasic (1998) definiu lipossomas como vesículas aquosas circundadas por bicamada concêntrica de fosfolipídios, que agem de forma sistêmica na liberação de fármacos devido à sua flexibilidade estrutural (tamanho, composição e fluidez da bicamada lipídica), e também à sua capacidade de incorporar variedade de compostos hidrofílicos e hidrofóbicos, como afirmou Pontes et al. (1999). Diebold et al. (2006) consideraram que os lipossomas são os sistemas manométricos mais estabelecidos clinicamente para a entrega de fármacos citotóxicos, genes e vacinas.

O tamanho dos lipossomas varia de $20 \mathrm{~nm}$ até alguns micrometros, com espessura de bicamada lipídica em torno de $6 \mathrm{~nm}$. Para Bergstrand et al. (2003), os lipossomas possibilitam a vetorização e a proteção do fármaco e o possível direcionamento para sítios específicos de células ou órgãos.

\section{OBJETIVOS}

\subsection{OBJETIVO GERAL}

O objetivo geral proposto para este estudo foi verificar a eficácia in vivo da terapia fotodinâmica tópica com ftalocianina cloro-alumínio de formulação lipossomal para o tratamento da Leishmania ( $L$ ) amazonensis, usada isoladamente ou em associação com a terapia sistêmica com miltefosina. 


\subsection{OBJETIVOS ESPECÍFICOS}

- Avaliar a eficácia do tratamento da leishmaniose causada pelo parasita Leishmania (L) amazonensis por meio da associação da terapia fotodinâmica com ftalocianina cloro-alumínio de formulação lipossomal e tratamento sistêmico com miltefosina.

- Comparar a eficácia da associação da miltefosina oral com ftalocianina cloroalumínio em formulação lipossomal tópica ao tratamento utilizando-se apenas miltefosina isoladamente.

- Comparar a eficácia da associação da miltefosina oral com ftalocianina cloroalumínio em formulação lipossomal tópica ao tratamento, utilizando-se apenas terapia fotodinâmica com ftalocianina cloro-alumínio em formulação lipossomal isoladamente.

- Realizar avaliação entre os grupos estudados por meio dos testes: (i) medição das patas; (ii) critérios parasitológicos (pesquisa de amastigotas em esfregaço de linfa, cultura em meio NNN e diluição limitante); e (iii) quantificação de parasita por pata usando software Elida.

\section{MATERIAIS E MÉTODOS}

\subsection{TIPO DE ESTUDO}

Estudo in vivo e do tipo experimental, em modelo animal (camundongo Mus musculus, C57BL/6).

\subsection{ISOLADOS DE Leishmania}

Foram utilizados formas promastigotas de Leishmania $L$. amazonensis (MHOM/BR/PH8) oriundas da OMS, identificadas pela técnica de isoenzimas e anticorpos monoclonais, mantidas em culturas criopreservadas em botijão de nitrogênio líquido $\left(-196^{\circ} \mathrm{C}\right)$ no laboratório de Dermatomicologia da Faculdade de Medicina da Universidade de Brasília. Essas culturas foram periodicamente inoculadas em camundongos isogênicos para assegurar a infectividade e garantir a virulência dos inóculos. 


\subsection{CONTAGEM DOS PARASITOS}

A contagem dos parasitos foi realizada com o suporte de uma câmara de Neubauer, na parte destinada à contagem de leucócitos (Figura 7), após a replicação das formas promastigotas. Na fase logarítmica de crescimento, os parasitos foram suspensos em uma diluição com $10 \mu \mathrm{L}$ do meio de cultura e $90 \mu \mathrm{L}$ de PSB, homogeneizada, e a câmara de Neubauer foi preenchida com uma alíquota dessa suspensão.

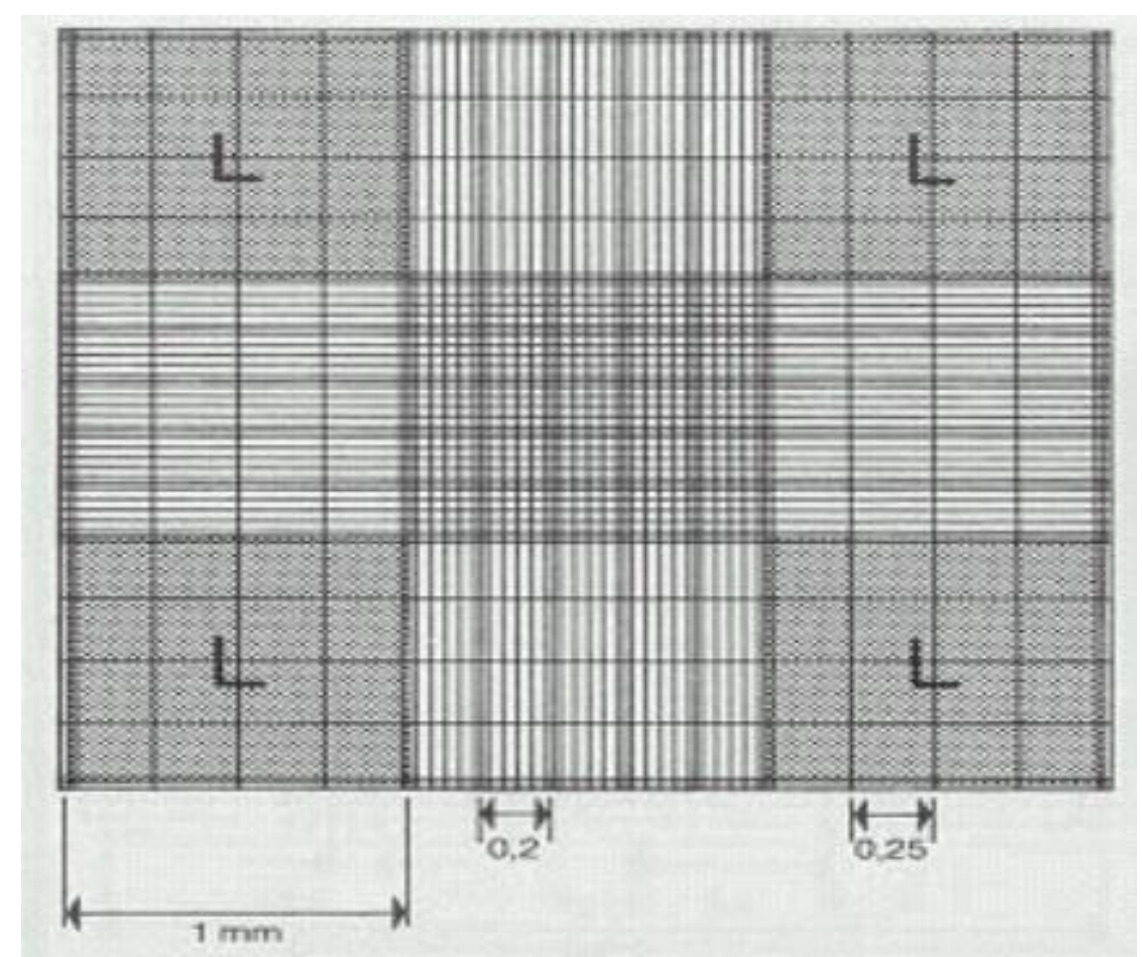

Figura 7: Câmara de contagem adaptada para microscópio de campo claro.

Conforme a Figura 7, a área marcada com $\mathrm{L}$ corresponde à parte da câmara para contagem de leucócitos. Dois quadrantes opostos foram contados (área marcada com L), calculada a média, e o número de parasitos foi dividido por dois.

Não foram contadas rosetas ou emaranhados, como critério de contagem. As formas promastigotas em divisão avançada foram contadas como dois. As formas no início da divisão foram contadas como um. As formas que estavam sobre a linha e muito próximas ao quadrante também foram contadas. 
A quantidade em volume de meio de cultura que contém $3 \times 10^{6}$ formas de promastigotas de Leishmania (L.) amazonensis por poço foi obtida após três contagens em câmara de Neubauer e obtenção da média das formas promastigotas.

\subsection{ANIMAIS}

Para este estudo, foram adotados 5 grupos, cada grupo composto por 6 animais fêmeas adultas ( $\mathrm{n}=30$ animais) da espécie Mus musculus, cepa C57BL/6, com aproximadamente $30 \mathrm{~g}$, e provenientes do Centro Multidisciplinar para Investigação Biológica na Área da Ciência em Animais de Laboratório (CEMIB), da Universidade Estadual de Campinas (UNICAMP). Todos os animais utilizados neste estudo possuíam atestado sanitário expedido pela médica veterinária $\mathrm{Dr}^{\mathrm{a}}$ Sônia Cano Montebelo Rachel, que comprova que os animais estavam livres de agentes patogênicos. Desses grupos, três foram de tratamento. O quarto grupo foi mantido com infecção e sem tratamento para servir como controle comparativo. $O$ quinto grupo foi o controle saudável, sem infecção e sem tratamento. O Quadro 5 demonstra as características apresentadas pelos animais, período de tratamento, fármacos e vias de administração.

Quadro 5: Esquema com padrões gerais para o tratamento com terapia fotodinâmica tópica com ftalocianina cloro-alumínio de formulação lipossomal associadas à miltefosina.

\begin{tabular}{c|c}
\hline Característica & Especificação \\
\hline Cepa de Camundongo & C57BL/6 \\
\hline Peso Médio por Camundongo & $\cong 31 \mathrm{~g}$ \\
\hline Sexo dos Camundongos & Fêmea \\
\hline Idade dos Camundongos & $\cong 121$ dias \\
\hline Via de Administração & Oral e Tópica \\
\hline Tempo de Tratamento & 20 dias \\
\hline Ftalocianina Cloro-Alumínio de formulação lipossomal (AICIFt) & $0,5 \mathrm{ml}$ \\
\hline Quantidade miltefosina & $200 \mathrm{MG} / \mathrm{kg} / \mathrm{dia}$ \\
\hline
\end{tabular}

Os animais foram mantidos no Biotério da Faculdade de Medicina, Universidade de Brasília, que apresenta infraestrutura adequada para o alojamento dos animais e médico veterinário responsável. Os camundongos ficaram em ambiente com controle de luminosidade, com ciclo de 12 horas no claro e 12 horas no escuro, e com água e ração ad libitum durante todo experimento. As gaiolas foram forradas com maravalha esterilizada. A idade mínima de cada camundongo para o início do tratamento era de 10 semanas. 
Os camundongos C57BL/6 foram preferidos por serem o modelo experimental que mais se aproxima do modelo humano na resposta ou manifestação da forma leishmaniose cutânea. Ao contrário das lesões causadas por Leishmania major, a maioria das lesões em cepas de camundongos C57BL/6 infectados por Leishmania (L) amazonensis, não tem cura espontânea. Com isso, os camundongos mostram variáveis graus de suscetibilidade à infecção e desenvolvem lesões crônicas que não curam.

Lemos et al. (2000) sugerem que exista um papel importante espécie-parasita na determinação do padrão de resposta imune. Acredita-se que a Leishmania $(L)$ amazonensis induz uma resposta imune de células $\mathrm{T}$ auxiliares do tipo Th2, a qual ajuda a ativar células $B$, resultando na produção de anticorpos, enquanto que $L$. major induz uma resposta do tipo Th1 em camundongos CBA, ativando macrófagos e resultando em uma resposta imune mediada por células. Acredita-se também que a suscetibilidade dos camundongos C57BL/6 para Leishmania (L) amazonensis esteja associada à ausência de resposta imune Th1, mas não é controlada exclusivamente por células Th2. A infecção por Leishmania (L) amazonensis tem sido relatada em camundongos C57BL/10 pela ausência da resposta do tipo Th1 ser suficiente para causar a multiplicação do parasita e desenvolvimento da lesão (LEMOS et al., 2000).

\subsection{AMOSTRAS}

Os fármacos empregados para o grupo de tratamento foram fornecidos por duas Universidades: miltefosina, fornecida pelo Hospital Universitário de Brasília (HUB), Universidade de Brasília (UnB); e ftalocianina cloro-alumínio em formulação lipossomal, fornecida pelo Departamento de Química da Universidade de São Paulo (USP) Campus Ribeirão Preto (Figura 8). 


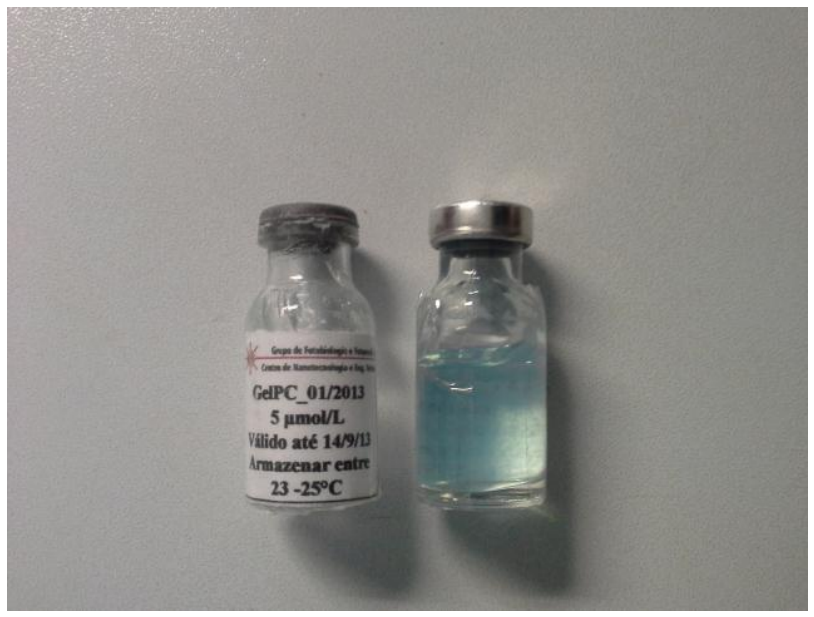

Figura 8: Amostras de ftalocianina de cloroalumínio em formulação limpossomal GeIPC, fornecidas pelo Departamento de Química da USP.

\subsection{CARACTERIZAÇÃO DOS GRUPOS}

Os 5 grupos definidos para esta pesquisa foram estabelecidos de acordo com os seguintes critérios descritos no Quadro 6.

Quadro 6: Caracterização dos grupos e esquema terapêutico utilizado.

\begin{tabular}{l|l}
\multicolumn{1}{c|}{ Grupo } & \multicolumn{1}{c}{ Caracterização do grupo } \\
\hline Controle negativo & Grupo não infectado não tratado. \\
\hline $\begin{array}{l}\text { Controle positivo } \\
\text { (PBS) }\end{array}$ & Grupo infectado não tratado. \\
\hline Miltefosina & Grupo infectado e tratado com miltefosina oral $200 \mathrm{mg} / \mathrm{Kg} /$ dia \\
\hline TFD com ftalo. & $\begin{array}{l}\text { Grupo infectado e tratado com terapia fotodinâmica com ftalocianina } \\
\text { cloro-alumínio de formulação lipossomal (AlCIFt). }\end{array}$ \\
\hline $\begin{array}{l}\text { Miltefosina + TFD } \\
\text { com ftalo }\end{array}$ & $\begin{array}{l}\text { Grupo infectado e tratado com miltefosina oral } 200 / \mathrm{mg} / \text { dia associado } \\
\text { à terapia fotodinâmica com ftalocianina cloro-alumínio de formulação } \\
\text { lipossomal (AlCIFt). }\end{array}$ \\
\hline
\end{tabular}

\subsection{VIA DE ADMINISTRAÇÃO}

As vias de administração adotadas para o desenvolvimento desta pesquisa foram a miltefosina oral e a ftalocianina cloro-alumínio de formulação lipossomal tópica. 


\subsection{QUESTÕES ÉTICAS}

Todos os procedimentos foram revisados e aprovados pelo Comitê de Ética no Uso Animal do Instituto de Biologia da Universidade de Brasília, cujo processo foi protocolado sob identificação UnBDoc 83795/2012 (Anexo 2).

\subsection{DESENHO EXPERIMENTAL in vivo}

\subsubsection{Infecção e confirmação da infecção}

Todos os cinco grupos que receberam os tratamentos e o grupo que foi infectado e não tratado foram submetidos à inoculação de um concentrado parasitário de $3 \times 10^{6}$ de formas promastigotas de Leishmania (L.) amazonensis, em fase metacíclica. Após a descriopreservação, foram cultivadas em meio de cultura Schneider's Insect Medium (Sigma-Aldrich ${ }^{\circledR}$ ) enriquecido com Soro Fetal Bovino (Gibco®) $20 \%$ e acrescido de sulfato de gentamicina (Laboratório Hipolabor ${ }^{\circledR}$ ) $0,2 \%$, a $37^{\circ} \mathrm{C}$. A infecção foi feita na pata traseira direita (Figura 9), via intradérmica, com o auxílio de uma seringa de insulina contendo $100 \mu \mathrm{L}$ de isolado de leishmania.

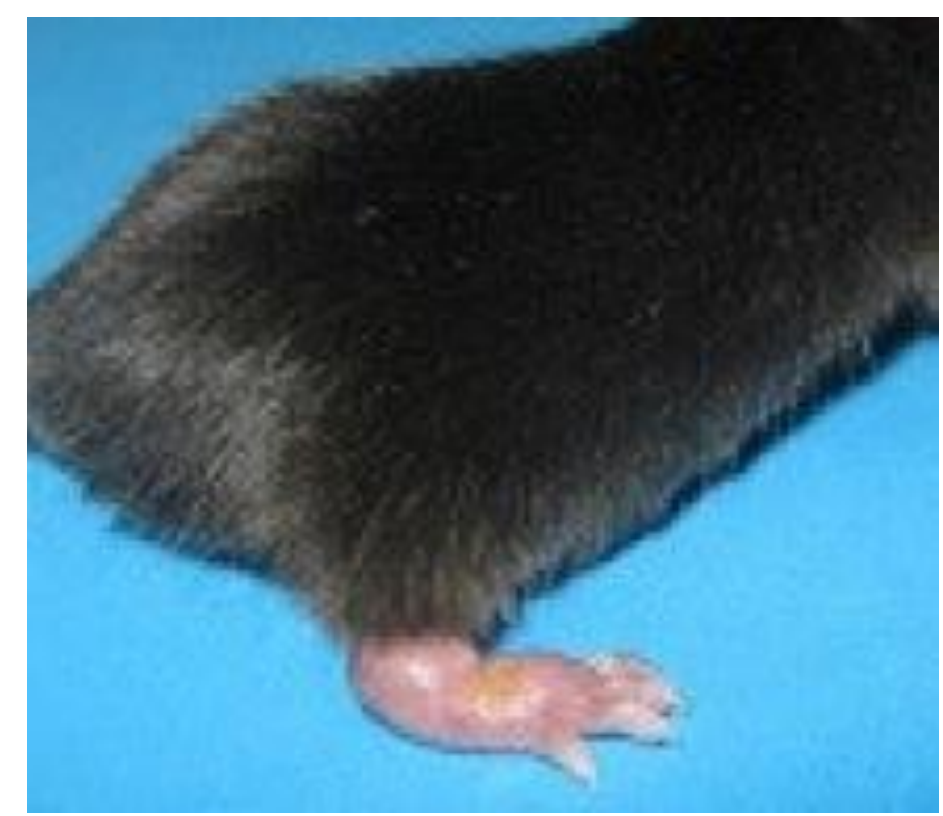

Figura 9: Lesão da pata em camundongo fêmea adulta cepa $\mathrm{C57BL} / 6$, espécie Mus musculus, infectada no coxim plantar direito via subcutânea, com $3 \times 10^{6}$ formas promastigotas de Leishmania amazonensis, em fase metacíclica, registrada com 30 dias de infecção. 
Após 30 dias da inoculação, realizou-se a confirmação da infecção, com a confecção de culturas (suspensas no meio bifásico Nove-McNeal-Nicolle-NNN), lâminas de extensão e pesquisa de amastigotas em esfregaços corados pela coloração de Giemsa. Coletou-se, então, exsudado das patas traseiras direitas, o qual foi analisado mediante a confecção de 30 (trinta) lâminas de extensão coradas com Giemsa, sendo seis para cada grupo, e observação em microscópio invertido. $O$ exsudado foi colocado em meio de cultura NNN, também avaliado em microscópio de luz invertida.

Tabela 3: Confirmação da infecção dos animais por pesquisa direta do parasita e cultura

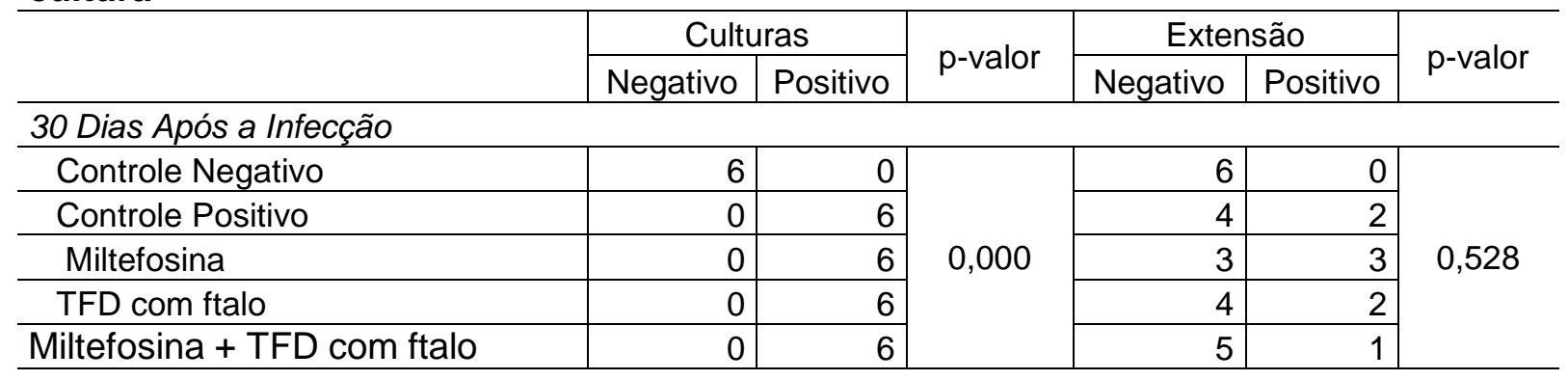

A Tabela 3 apresenta a avaliação dos 30 animais para os testes de cultura e lâminas de extensão. Demonstra que, ao iniciar o esquema terapêutico utilizado neste estudo, todos os grupos onde os animais receberam tratamento estavam infectados. A avaliação da infecção pela confecção de lâminas de extensão não apresentou infecção em todos os animais de todos os grupos. Isso foi decorrente da dificuldade encontrada pela técnica de fixação e coloração de lâminas em encontrar os parasitas fixados. Entretanto, a confirmação feita pela confecção de culturas demonstrou $100 \%$ de infecção nos animais que compõem o grupo infectado e não tratado e os três grupos que receberam o tratamento.

\subsubsection{Tratamento e esquemas terapêuticos utilizados}

Os animais foram tratados durante o período de 20 dias, período preconizado pela OMS para o tratamento de humanos. Os 30 camundongos C57BL/6 foram categorizados em cinco grupos distintos, cada um com 6 animais: (1) controle negativo; (2) controle positivo; (3) miltefosina $200 \mathrm{mg}$; (4) TFD com ftalocianina de cloro-alumínio em formulação lipossomal; (5) miltefosina $200 \mathrm{mg}$, diariamente associada à TFD com ftalocianina de cloro-alumínio em formulação lipossomal em 
dias alternados. Foi instituído um esquema terapêutico nos animais em um período de vinte dias.

O Grupo 1, que serviu como grupo controle negativo, recebeu solução fisiológica por via oral no período de vinte dias (diariamente) para que não ocorresse nenhuma diferença de nível de estresse com relação aos grupos que receberiam os medicamentos. Essa definição foi necessária porque acredita-se que o nível de estresse pode impactar diretamente no sistema imunológico do animal. O Grupo 1 não foi infectado com cepas de Leishmania (L.) amazonensis e nem tratado com os medicamentos em estudo (miltefosina e ftalocianina), pois este grupo serviu como parâmetro para comparação com os grupos que receberam carga parasitária.

O Grupo 2, que serviu como grupo controle positivo, assim como o Grupo 1, recebeu solução fisiológica por via oral no período de vinte dias (diariamente). Este grupo foi infectado com Leishmania (L.) amazonensis e não foi tratado com os medicamentos em estudo. O Grupo 2 também serviu como parâmetro para comparação com os grupos que receberam carga parasitária, pois com base nele foi possível avaliar se houve ou não evolução do tratamento com redução dos parasitas nos grupos que receberam tratamento com medicamentos. Esperou-se, desta forma, que o Grupo 2, mantivesse uma carga parasitária superior aos dos grupos que receberam tratamento com os medicamentos em estudo.

O Grupo 3 foi infectado com cepas de Leishmania (L.) amazonensis e tratado durante o período de vinte dias com administração oral e diária de miltefosina 200 mg. Essa estratégia foi adotada porque o miltefosina já é uma droga consagrada para o tratamento contra às leishmanioses (ALMEIDA, 2011).

O Grupo 4 foi infectado com cepas de Leishmania (L.) amazonensis e tratado durante o período de vinte dias intercalados com terapia fotodinâmica com ftalocianina em formulação lipossomal.

O Grupo 5 foi infectado com cepas de Leishmania (L.) amazonensis e tratado durante o período de vinte dias com miltefosina $200 \mathrm{mg}$ e terapia fotodinâmica com ftalocianina em formulação lipossomal. Durante o tratamento de vinte dias os animais deste grupo receberam doses diárias, por via oral, de miltefosina. A terapia 
fotodinâmica com ftalocianina foi administrada em dias intercalados porque, como os animais precisam estar anestesiados para aplicação da TFD, a sua administração diária seria prejudicial aos animais, levando-Ihes à morte. Tal constatação advém de um teste piloto realizado antes da aplicação desta pesquisa.

Para os dias de aplicação da TFD, os animais, necessariamente, precisaram estar imobilizados para incidência da luz de laser sobre a pata do animal (Figura 10). Para tanto, optou-se por anestesiar e sedar os animais com associação de xilazina (cloridrato de xilazina), que produz no animal sedação com analgesia e o animal retorna ao seu estado normal, e Quetamina (cloridrato de ketamina), por via intramuscular, que leva normalmente 1 a 5 minutos para produzir sedação.

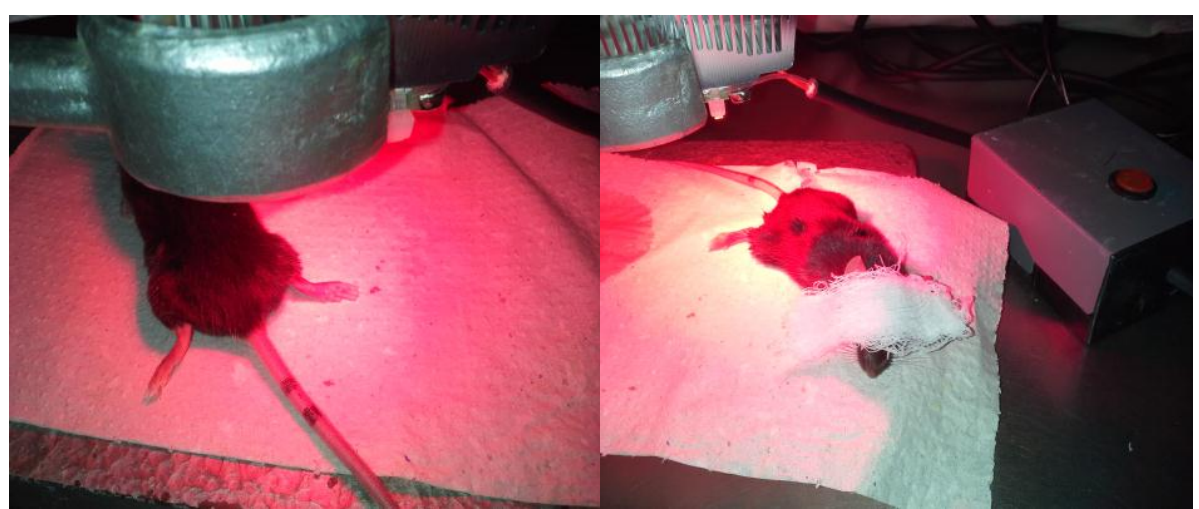

Figura 10: Camundongo C57BL/6 sedado sob exposição à luz visível

Os animais foram mantidos anestesiados por 40 minutos para aplicação das medicações. Esta técnica consiste na imobilização do camundongo em decúbito ventral, extensão do membro posterior esquerdo e injeção da solução na região postero-lateral da coxa. A associação padrão é de $10 \mathrm{mg} / \mathrm{kg}$ de xilazina e $90 \mathrm{mg} / \mathrm{Kg}$ de Quetamina, sendo o cálculo realizado para o peso médio do animal, que foi de 30 g. Para isso, foi utilizada uma seringa de $1 \mathrm{ml}$. Então, esperou-se cerca de 3 minutos até que a associação dos anestésicos fizesse efeito e, com o animal sedado, foi aplicado $500 \mu \mathrm{L}$ do gel contendo alumínio-cloro-ftalocianina (AICIFt) sobre a lesão, perfazendo uma camada de $1 \mathrm{a} 2 \mathrm{~mm}$ na pata direita traseira, que foi envolvida em folha de alumínio de $3 \times 4 \mathrm{~cm}$ para evitar penetração da luz (Figura 11). Este valor foi determinado pela área da lesão (tamanho da pata). 


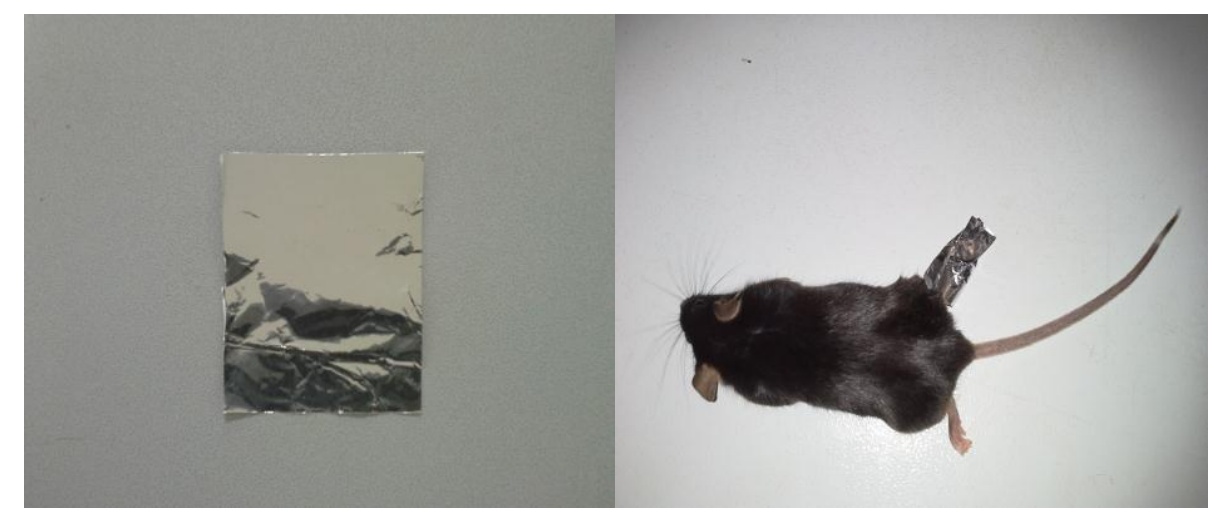

Figura 11: Folha de alumínio e sua aplicação em camundongo C57BL/6 aguardando 15 minutos para absorção da ftalocianina.

Após a sedação, os animais foram levados a uma sala reservada do laboratório de cirurgia experimental (CIEX), por apresentar um ambiente totalmente escuro, impedindo a ativação da ftalocianina antes da absorção. Foram aguardados mais 15 minutos até que houvesse absorção (pelo menos parcial) do gel pela derme do animal. A aplicação do gel foi feita com o auxílio de uma haste flexível estéril descartada após a aplicação para cada animal. A folha de alumínio foi removida e então a pata contendo o gel foi exposta à irradiação de luz visível, com comprimento de onda $670 \mathrm{~nm}$, liberando $100 \mathrm{~J} / \mathrm{cm}^{2}$ a uma intensidade de $80 \mathrm{~mW} / \mathrm{cm}^{2}$, o que determina um tempo de exposição de 15 minutos. Durante os 15 minutos de aplicação do laser, optou-se por aplicar gaze embebida em solução fisiológica a 0,9\% para evitar o ressecamento do globo ocular dos animais. A distância entre a fonte de luz e a lesão foi de $05 \mathrm{~cm}$ (Figura 12).

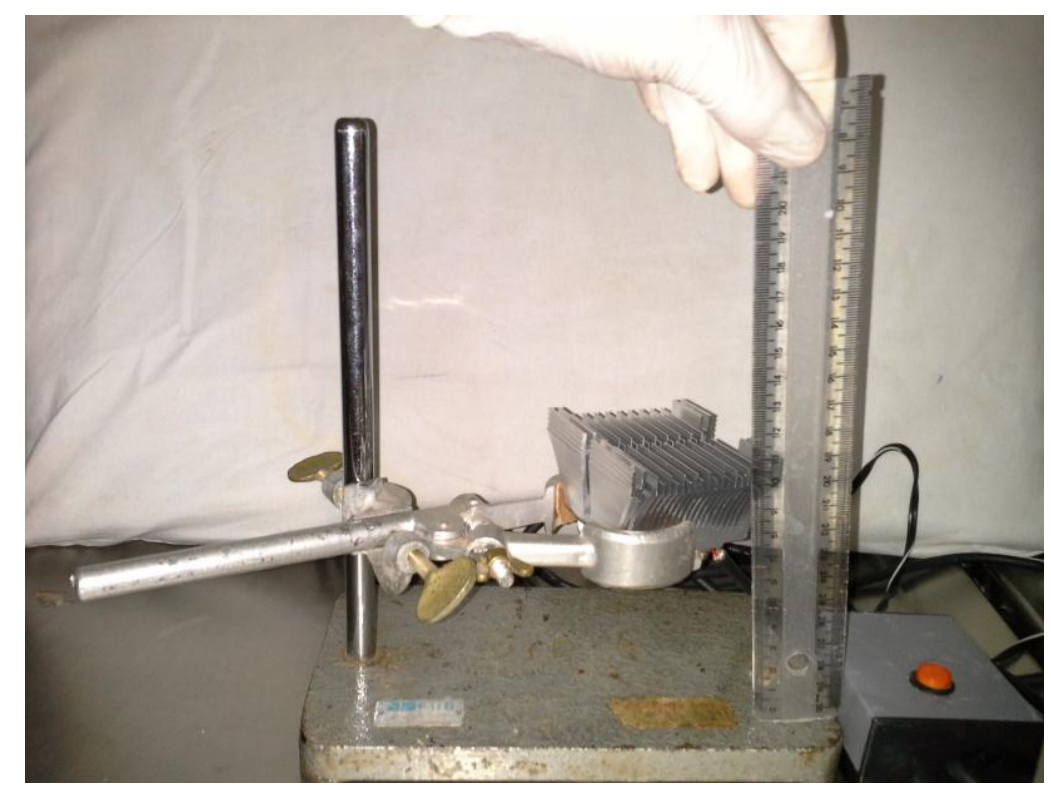

Figura 12: Aparelho de luz visível posicionado a $5 \mathrm{~cm}$ da base. 
Após cada sessão de TFD, os resíduos do gel foram removidos utilizando-se soro fisiológico $0,9 \%$ e o animal retornou ao seu estado de alerta após cerca de 10 minutos do término da aplicação, em sala específica sob observação para avaliação do retorno anestésico. Confirmado o retorno anestésico, os animais foram devolvidos ao biotério da Faculdade de Medicina.

\subsection{EUTANÁSIA DOS ANIMAIS}

Para a coleta de linfa e confecção dos testes realizados neste estudo, os animais foram anestesiados como previamente mencionado, ou seja, a mesma dose administrada no tratamento com TFD.

Feita a coleta, os animais foram levados à câmara de saturação de $\mathrm{CO}_{2}$ (Laboratório de Cirurgia Experimental da Faculdade de Medicina da Universidade de Brasília), fechada de maneira a atingir uma saturação superior a $70 \%$, onde foram eutanasiados individualmente até a parada cardiorrespiratória. Na sequência, realizou-se a dissecação mais asséptica possível da pata traseira direita de quatro camundongos de cada grupo. Esta técnica consistiu em fazer assepsia das patas inoculadas, que em seguida foram maceradas com o auxílio do homogeneizador em meio de cultura Schneider, acrescido de $20 \%$ de soro fetal bovino inativado a $0,2 \%$ de sulfato de gentamicina, cedida pelo Serviço de Dermatologia do Hospital UnB. Para o descarte, os cadáveres foram devidamente alocados em sacos plásticos brancos e mantidos sob refrigeração a $-20^{\circ} \mathrm{C}$ no freezer do biotério da Faculdade de Medicina da UnB, para posterior incineração.

\subsection{CRITÉRIOS DE AVALIAÇÃO DE EFICÁCIA}

Após as formas de tratamento indicadas, os animais foram avaliados segundo os critérios de: (i) medição das patas; (ii) critérios parasitológicos (pesquisa de amastigotas em esfregaço de linfa, cultura em meio NNN e diluição limitante); e (iii) quantificação de parasita por pata usando software Elida. 


\subsection{MEDIÇÃO DO DIÂMETRO DAS PATAS}

O diâmetro das patas inoculadas dos camundongos foi medido com o auxílio de dois paquímetros milimétrico Mitutoyo® (Figura 13), com precisão de décimos de milímetros, antes e após a infecção, e ao término do tratamento. Em seguida, foi realizada a comparação dos diâmetros de cada um dos grupos após o tratamento com os valores encontrados pré-tratamento e entre os grupos tratados entre si. Optou-se por desempenhar duas medidas, uma com cada paquímetro, para aumentar a precisão e evitar erros de resultados.

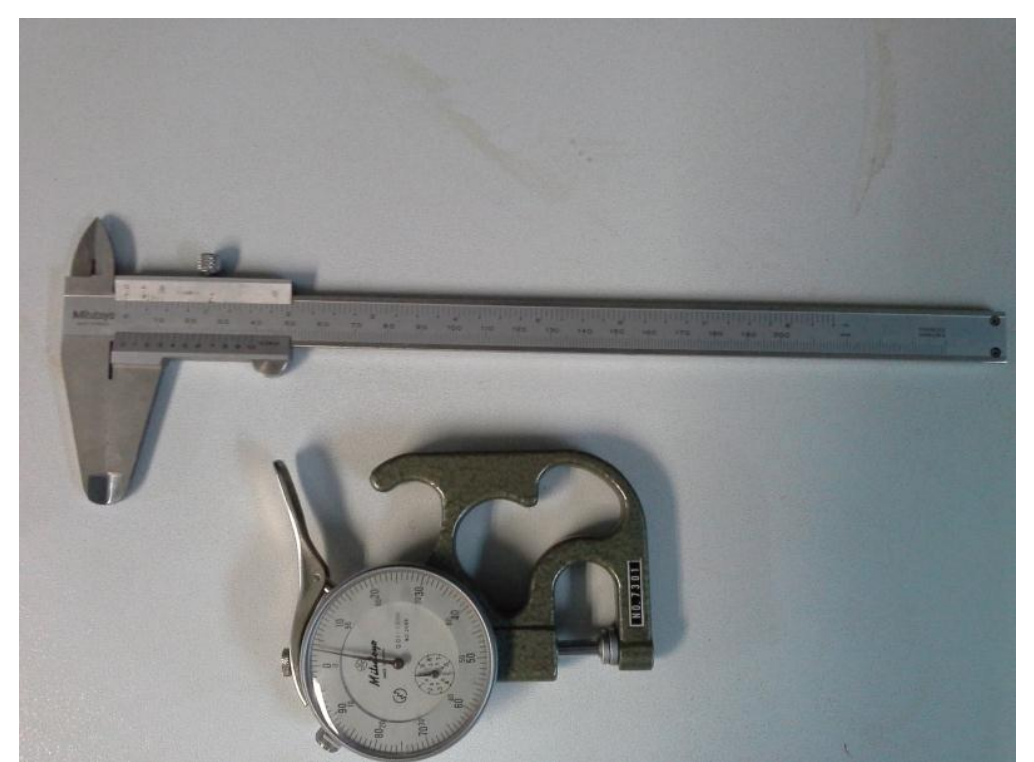

Figura 13: Paquímetros milimétrico Mitutoyo ${ }^{\circledR}$ utilizados para medida das patas dos animais.

\subsection{CRITÉRIOS PARASITOLÓGICOS}

Imediatamente após o término do tratamento foram extraídas amostras de linfa por punção das patas inoculadas, para a realização de culturas tradicionais (suspensas no meio bifásico Nove-McNeal-Nicolle-NNN) e pesquisa de amastigotas em esfregaços corados pela coloração de Giemsa. Realizou-se também o método da diluição limitante. Este é um método para estipulação da quantidade provável de formas amastigotas de Leishmania viáveis na pata do animal, feito a partir da sua dissecção asséptica, homogeinização das patas com o auxílio de homogeneizador de vidro (Figura 14), trituração em meio de cultura líquido Schneider (Sigma®) acrescido de $10 \%$ de soro fetal bovino e $0,2 \%$ de gentamicina, seguido de culturas 
em placas tipo ELISA (96 poços) em sucessivas diluições de 10 vezes (CARVALHO, 2011). Para esse método foram utilizadas as patas de dois camundongos diferentes por grupo de estudo. Caso houvesse uma amastigota em cada poço, cresceriam formas promastigotas após cerca de 24 a 72 horas em estufa a $26^{\circ} \mathrm{C}$. A leitura então foi feita em microscópio de luz invertida com objetiva de aumento 40 vezes, onde observou-se a presença ou ausência de formas promastigotas em cada poço (CARVALHO, 2011). Os resultados obtidos foram analisados com auxílio do software ELIDA que calculou o número provável de amastigotas por pata utilizada.

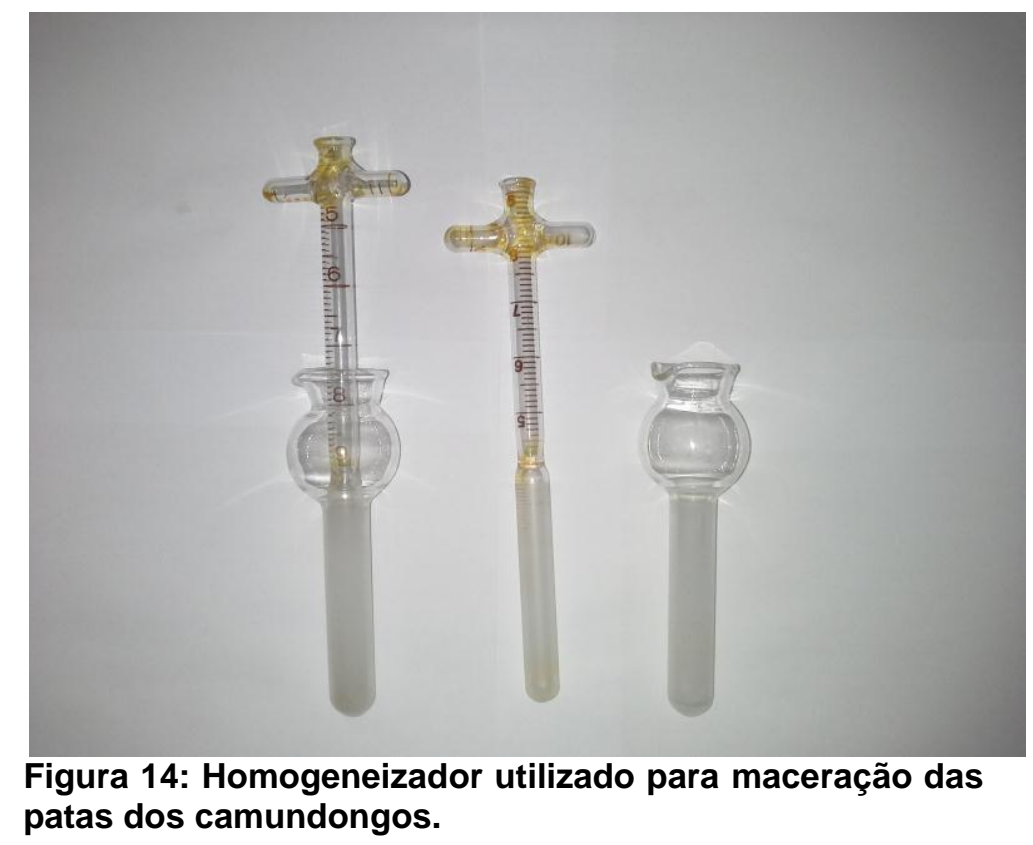

A cultura de diluição limitante seguida pelo método colorimétrico com o uso de MTT (brometo de 3-[4,5-dimetil tiazol-2-il]-2,5-difenil-tetrazólio) consiste em estimar as formas amastigotas de Leishmanias (L.) amazonensis viáveis na pata do animal, ou seja, analisa-se se o tratamento diminui o número de Leishmanias a partir da dissecação da pata do animal, sua trituração em meio de cultura líquido Schneider $\left(\right.$ Sigma $\left.^{\circledR}\right)$, seguida de culturas em placas ELISA de 96 poços em sucessivas diluições de 10 vezes. A leitura da placa foi feita em leitor de placa de Elisa a 570 nm (Figura 15) (URDAPILLETA, 2006). 


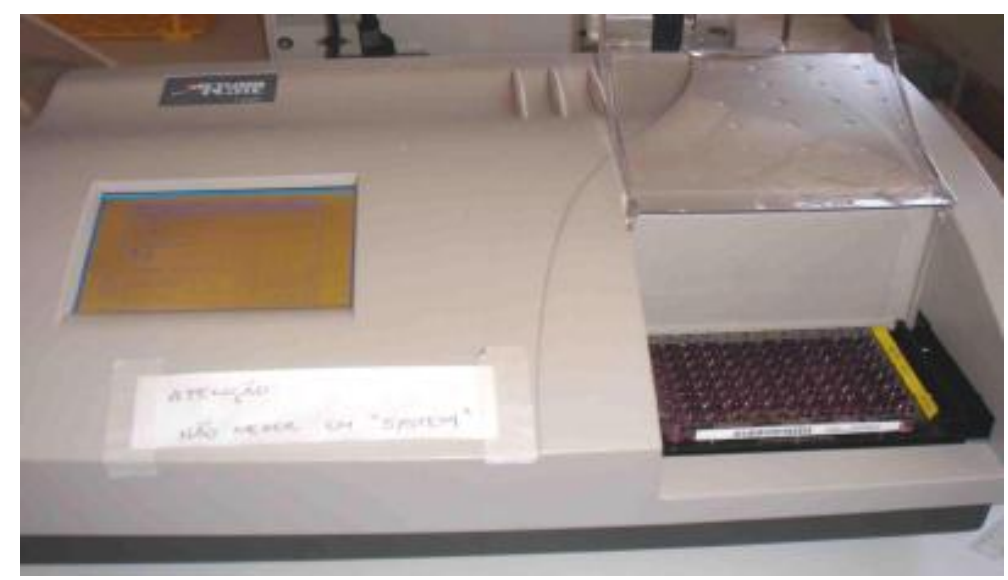

Figura 15: Placa de 96 poços no Leitor de ELISA a 570 nm

\subsection{CARACTERIZAÇÃO DOS LIPOSSOMAS CONTENDO FTALOCIANINA DE CLORO-ALUMÍNIO (AICIFt)}

As amostras de partículas de lipossoma em gel, contendo ftalocianina de cloro-alumínio em formulação lipossomal, foram colocadas com auxílio de espátula sobre as telas de Microscópio Eletrônico Transmissão (MET), previamente cobertas com Formvar®. Aguardou-se 3 horas para secagem em temperatura $25^{\circ} \pm 2^{\circ} \mathrm{C}$. Em seguida, as eletromicrografias foram obtidas pelo MET, JEOL 1011 (Jeol, Tóquio, Japão). As partículas foram levadas para Microscópio de Varredura (MEV), JEOL JSM-7001F (Jeol, Tóquio, Japão / sistema EDS [Energia dispersiva de raio-X]) no Laboratório de Microscopia Eletrônica da UnB. Dessa forma, foi possível verificar as características morfológicas e arquitetônicas da solução em gel do lipossoma. $\mathrm{O}$ diâmetro médio das partículas de lipossoma foi calculado pelo programa Image-Pro Plus $6.0 \mathrm{com}$ imagens do MET.

Para verificar o índice de polidispersão (Idp), potencial Zeta e diâmetro hidrodinâmico das partículas lipossomais, utilizou-se o equipamento ZetaSizer Nano ZS (Malvern Instruments, Malvern, UK) do Laboratório de Nanobiotecnologia da UnB. As amostras da solução em gel do lipossoma, contendo ftalocianina de cloroalumínio em formulação lipossomal, foram diluídas na proporção 1:50 com água destilada para leitura no ZetaSizer. 


\subsection{ANÁLISE ESTATÍSTICA}

As análises estatísticas foram realizadas usando o software SPSS (Statistical Package for the Social Sciences), versão 20.0. As variáveis quantitativas foram testadas para distribuição normal com o teste de Shapiro-Wilk. Para as variáveis "diâmetro das patas" e "MTT" possíveis diferenças entre os grupos analisados foram investigadas pelo teste de Kruskal-Wallis (dados não normalizados), sendo o teste de Mann-Whitney usado para verificar diferenças entre os tratamentos (comparações dois a dois). Possíveis diferenças dentro de cada grupo (antes da infecção, após 2 e 30 dias de infecção e após 20 dias de tratamento) foram testadas pelo teste de Friedman seguido pelo teste de Wilcoxon para as comparações dois a dois. Para avaliar a associação das variáveis lâminas de extensão e culturas em meio NNN com o grupo nos momentos distintos, foi aplicado o Teste Exato de Fisher que, quando significativo, indica que há associação entre as variáveis, ou seja, o grupo influencia o resultado nas lâminas de extensão ou cultura em meio NNN (FIED, 2009). O número de parasitas viáveis por pata foi determinado pelo programa Elida $\AA$, que infere estatisticamente 0 ensaio da diluição limitante. Para a comparação das médias, foi usada Análise de Variância (ANOVA), seguida pelo pós-teste de Tukey. Valores de $p<0.05$ foram considerados estatisticamente significativos.

\section{RESULTADOS}

\subsection{RESULTADOS DA CARACTERIZAÇÃO DOS LIPOSSOMAS CONTENDO FTALOCIANINA DE CLORO-ALUMÍNIO}

O diâmetro médio da solução lipossomal analisada pelo MET foi $52.9 \pm 12.4$ nm (Gráfico 1). A característica morfológica foi obtida pelo MEV. A solução em gel de lipossoma apresentou várias camadas e entre elas presença dos lipossomas em formatos disformes provavelmente pelo processamento da técnica. 


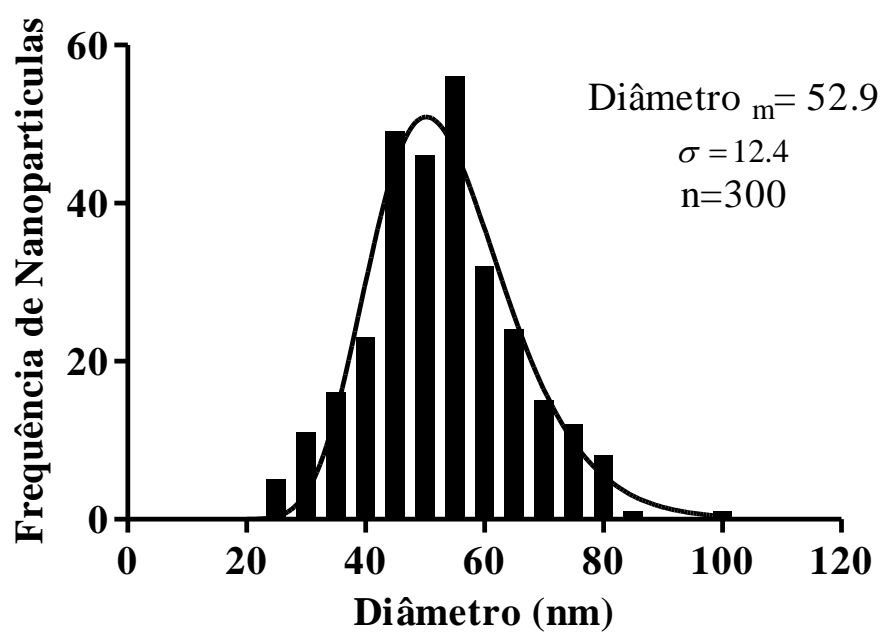

Gráfico 1: Diâmetro médio da solução lipossomal analisada pelo MET

Foi possível também observar mais livres (fora das camadas do gel) a presença de fragmentos do alumínio no formato cúbico com superfície lisa (Figura 16). O sistema EDS confirmou a presença marcante dos íons $\mathrm{Si}, \mathrm{Na}, \mathrm{Mg}, \mathrm{Al}, \mathrm{K}, \mathrm{Ca}$ em toda amostra analisada. Esses dados confirmam a natureza dos compostos presente nas amostras sintetizadas. Percebe-se um pico de $\mathrm{Si}$ e alumínio, constatação dentro do esperado. O lipossoma é lipídio e este é constituído de hidrogênio, oxigênio, carbono e fósforo. O EDS apresenta $\mathrm{C}, \mathrm{O}, \mathrm{Na}, \mathrm{K}$ que podem ser do lipossoma.

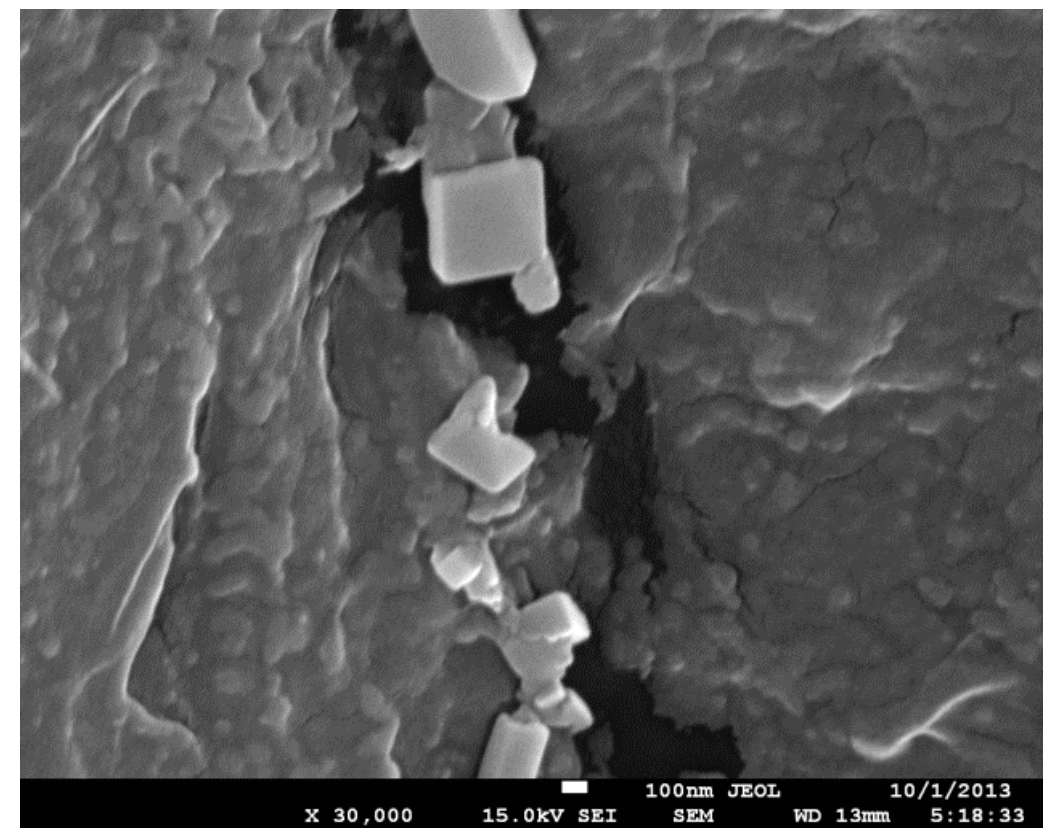

Figura 16: Presença de fragmentos do alumínio no formato cúbico com superfície lisa 
O diâmetro médio das partículas lipossomais medido pela ZetaSize foi $266.9 \pm$ 5.2. Esse tamanho é extremamente importante para condução de estudos in vivo e in vitro. Caso o tamanho dos lipossomas fosse grande, acima de $300 \mathrm{~nm}$, comprometeria sua utilização como veículo de entrega de droga, pois ele seria rapidamente removido da corrente sanguínea por células de defesa (macrófagos).

O índice de polidispersão da solução lipossomal ficou em $0.55 \pm 0.04$ indicando pouca homogeneidade de dispersão. Isso pode ter sido provocado pela adição de ftalocianina cloro-alumínio gerando perda da homogeneidade da composição lipossomal.

\subsection{MEDIDA DAS LESÕES CUTÂNEAS (DIÂMETRO DAS PATAS) ANTES DA INFECÇÃO, 2 DIAS APÓS A INFECÇÃO, 30 DIAS APÓS A INFECÇÃO E APÓS 20 DIAS DE TRATAMENTO.}

Para avaliar a eficácia do tratamento por meio da medição das patas com o paquímetro, foram feitas quatro medições em tempos distintos, como demonstrado no Gráfico 2.

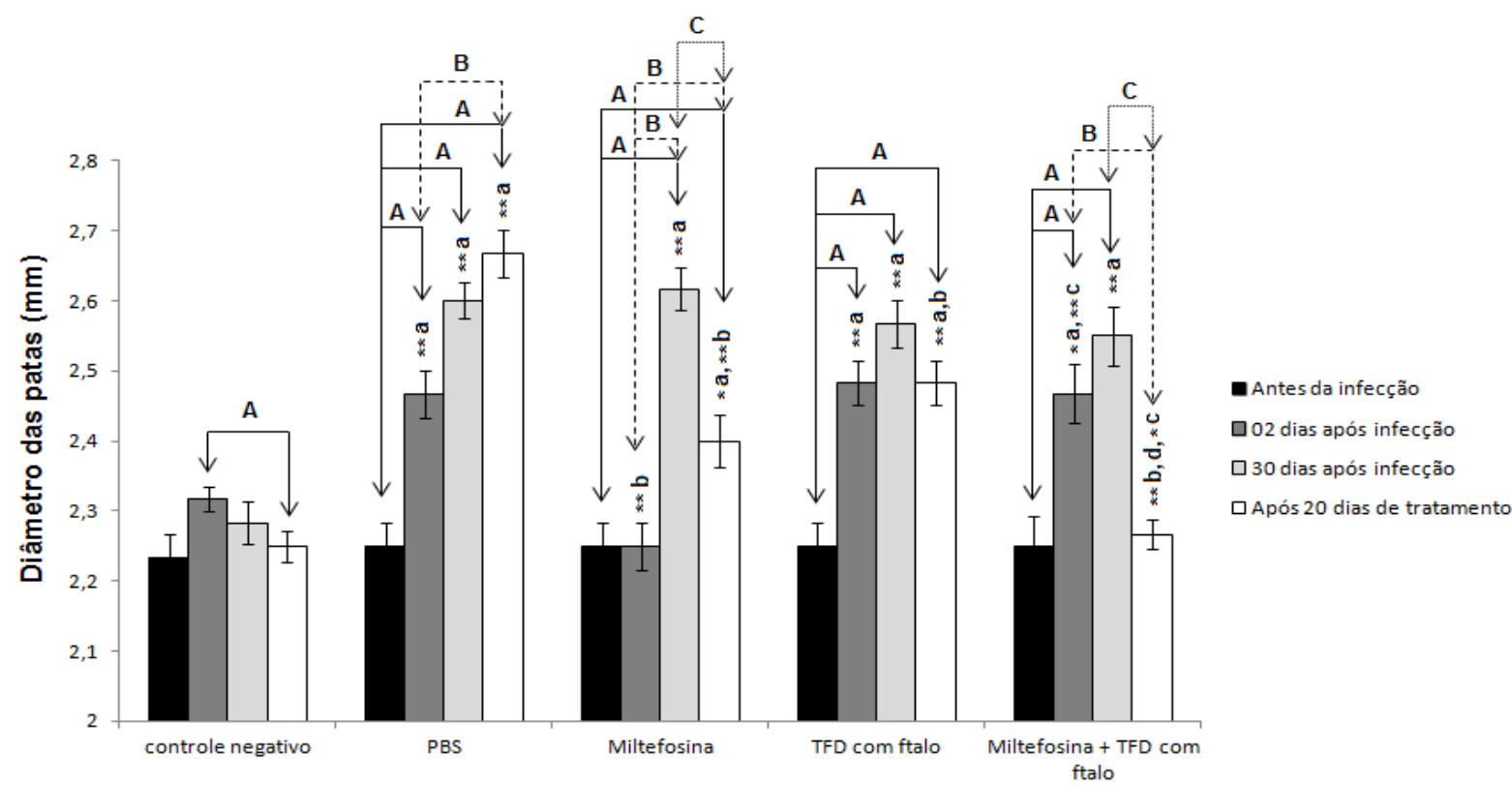

Gráfico 2: Diâmetro das patas dos animais antes da infecção, após 2 e 30 dias de infecção (confirmação da infecção) e após 20 dias de tratamento.

Os dados correspondem à média e ao erro padrão da média (EPM). As letras minúsculas indicam diferenças significativas detectadas pelo teste de Mann-Whitney nas comparações verticais 2-a-2 (entre os grupos), sendo $a=$ significativo comparado com o controle negativo; $b=$ significativo comparado ao controle positivo (PBS); $c=$ significativo comparado ao grupo tratado com miltefosina; $d=$ significativo comparado ao grupo tratado com terapia fotodinâmica com ftalocianina cloro-alumínio de formulação lipossomal. Os asteriscos indicam diferenças significativas $\left({ }^{*} p<0,05\right)$ ou altamente significativas $\left({ }^{* *} p<0,01\right)$. As letras maiúsculas indicam diferenças significativas $(p<0,05)$ nas comparações horizontais (dentro de cada grupo) detectadas pelo teste de Wilcoxon, sendo: A (setas com linha contínua) = significativo comparado a antes da infecção; B (setas linha tracejada) = significativo comparado a 02 dias após infecção; C (setas com linha pontilhada) = significativo comparado a 30 dias após infecção. 
A primeira medição foi feita antes do início do tratamento para servir como parâmetro de pata não infectada, ou seja, sem a presença de parasitas ou qualquer tipo de manipulação. Esta medida não apresentou diferença estatística entre os grupos em estudo, o que indica que o diâmetro das patas dos animais dos grupos antes do início do experimento apresentava uniformidade $(p<0,05)$.

A segunda medida foi feita dois dias após a infecção. Esta segunda medida se fez importante, pois foi observado que o trauma causado pela inoculação dos parasitas nas patas fez com que o diâmetro das patas aumentasse em decorrência do trauma causado e não pelo crescimento de parasitas. Esta evidência de aumento do diâmetro das patas pode ser observada em todos os grupos, inclusive no grupo controle negativo, onde não foi feita a infecção com parasitas e sim a administração de água destilada.

A terceira medição foi feita após trinta dias de infecção, e serviu para confirmar o crescimento do diâmetro das patas causado pela multiplicação dos parasitas que iniciam o processo de lesão. Para esta medida foi possível analisar por meio do Gráfico 2 que, com exceção do grupo controle negativo, todos os outros grupos apresentaram crescimento expressivo do diâmetro das patas, indicando a instalação da lesão causada pela presença dos parasitas.

A quarta e última medição foi feita ao final do tratamento, após os animais serem tratados por um período de vinte dias. Esta medida serviu para avaliar a eficácia do tratamento comparando os grupos por meio do teste de Mann-Whitney nas comparações verticais. No grupo controle negativo foi possível observar que não houve diferença estatística entre as medidas que foram realizadas antes do início do tratamento e após vinte dias de tratamento. Para o grupo controle positivo foi possível observar que houve um aumento progressivo do diâmetro das patas, desde o período que antecede a infecção até o final dos 20 dias de tratamento, indicando que ocorreu progressão da lesão por não ter sido realizado nenhum tratamento.

O grupo tratado com miltefosina apresentou diferença estatística nas medidas realizadas antes do início do tratamento (antes dos 30 dias de tratamento) e com vinte dias de tratamento, o que confirma a infecção. Após o tratamento, ocorreu regressão significativa do diâmetro das patas. $O$ grupo tratado isoladamente com 
TFD com ftalocianina cloro-alumínio em formulação lipossomal demonstrou diferença altamente significativa quando comparamos o período que antecede a infecção e os períodos de trinta dias de infecção e vinte dias após o tratamento. Entretanto, não houve diferença estatística nos períodos de trinta dias de infecção e vinte dias após o tratamento.

No quinto e último grupo, no qual os animais foram tratados com a associação da miltefosina e TFD com ftalocianina de cloro-alumínio em formulação lipossomal, foi possível observar diferença estatística significativa entre os períodos que antecederam a infecção, trinta dias após a infecção. Infere-se, assim, que houve aumento do diâmetro das patas, logo houve aumento da lesão. Entretanto, após os vinte dias de tratamento, este grupo apresentou expressiva redução do diâmetro das patas, superando inclusive o grupo que utilizou apenas a miltefosina, o que torna este grupo o que mais se aproximou do grupo controle negativo.

\subsection{ANÁLISE DA EFICÁCIA POR MEIO DA CONFECÇÃO DE 30 CULTURAS EM MEIO BIOFÁSICO NNN}

As culturas realizadas antes do início do tratamento, ou seja, com trinta dias após a infecção dos animais, demonstraram 100\% (24/24) de confirmação da infecção para os grupos que receberam tratamento e o grupo infectado e não tratado. O grupo controle negativo como já era esperado não apresentou presença de parasitas em nenhuma das culturas confeccionadas, ou seja, apresentou $100 \%$ (6/6) de negatividade como demonstrado na (Tabela 4).

Tabela 4: Relação de culturas negativas e positivas $\mathbf{3 0}$ dias após a infecção e ao final de 20 dias de tratamento

\begin{tabular}{|c|c|c|c|}
\hline \multirow{2}{*}{ Teste Exato de Fisher } & \multicolumn{2}{|c|}{ Culturas } & \multirow{2}{*}{ p-valor } \\
\hline & Negativo & Positivo & \\
\hline \multicolumn{4}{|l|}{30 Dias Após a Infecção } \\
\hline Controle Negativo & 6 & 0 & \multirow{5}{*}{0,000} \\
\hline Controle Positivo (PBS) & 0 & 6 & \\
\hline Miltefosina $200 \mathrm{mg}$ & 0 & 6 & \\
\hline TFD com ftalo & 0 & 6 & \\
\hline Miltefosina $200 \mathrm{mg}+$ TFD com ftalo & 0 & 6 & \\
\hline \multicolumn{4}{|l|}{ Após 20 Dias de Tratamento } \\
\hline Controle Negativo & 6 & 0 & \multirow{5}{*}{0,005} \\
\hline Controle Positivo (PBS) & 0 & 6 & \\
\hline Miltefosina $200 \mathrm{mg}$ & 4 & 2 & \\
\hline TFD com ftalo & 3 & 3 & \\
\hline Miltefosina $200 \mathrm{mg}+$ TFD com ftalo & 5 & 1 & \\
\hline
\end{tabular}


Após os 20 dias de tratamento, foram feitas novamente culturas em todos os animais de cada grupo, sendo todas negativas $100 \%$ (6/6) para os animais do grupo controle negativo, e todas positivas $100 \%$ (6/6) para os animais do grupo controle positivo. A análise dos dados da Tabela 5 revelou ainda que houve redução da positividade das culturas para os três grupos em tratamento. $O$ grupo tratado somente com miltefosina apresentou redução significativa das culturas positivas. De todos os animais testados por meio da confecção das culturas apenas 33,3\% (2/6) positivaram. Já no grupo que recebeu apenas o tratamento com TFD e ftalocianina de cloro-alumínio em formulação lipossomal, a positividade nas culturas foi de $50 \%$ (3/6). O grupo tratado com a associação das drogas miltefosina e TFD com ftalocianina de cloro-alumínio em formulação lipossomal, apresentou o melhor resultado entre os três grupos em tratamento. Este grupo superou a eficácia do grupo que utilizou apenas a droga considerada padrão ouro, miltefosina, onde houve positividade das culturas em apenas $16,6 \%$ (1/6) dos animais que receberam tratamento

\subsection{ANÁLISE DA EFICÁCIA POR MEIO DA CONFECÇÃO DE 30 LÂMINAS DE EXTENSÃO FIXADAS E PORTERIORMENTE CORADAS COM GIEMSA}

A avaliação da eficácia por meio de lâminas de extensão, confeccionadas a partir da coleta de exsudado das patas traseiras direitas dos animais, e posteriormente fixadas e coradas pela coloração de Giemsa, é uma técnica de difícil execução e um método com baixa sensibilidade pela dificuldade em se fixar e corar os parasitos nas lâminas. Essa sensibilidade depende do grau de parasitismo, do tipo de material biológico coletado, do seu processamento e coloração (BARBOSA et al., 2012). Diante deste cenário, não foi possível confirmar a infecção de todos os animais após 30 dias de infecção, sendo confirmada a presença do parasita apenas em 33,3\% (8/24) dos animais que foram inoculados como demonstrado na Tabela 5. 
Tabela 5: Relação de lâminas de extensão negativas e positivas $\mathbf{3 0}$ dias após a infecção e ao final de $\mathbf{2 0}$ dias de tratamento

\begin{tabular}{|c|c|c|c|}
\hline \multirow{2}{*}{ Teste Exato de Fisher } & \multicolumn{2}{|c|}{ Lâminas Extensão } & \multirow{2}{*}{$p$-valor } \\
\hline & Negativo & Positivo & \\
\hline \multicolumn{4}{|l|}{30 Dias Após a Infecção } \\
\hline Controle Negativo & 6 & 0 & \multirow{5}{*}{0,528} \\
\hline Controle Positivo (PBS) & 4 & 2 & \\
\hline Miltefosina $200 \mathrm{mg}$ & 3 & 3 & \\
\hline TFD com ftalo & 4 & 2 & \\
\hline Miltefosina $200 \mathrm{mg}+$ TFD com ftalo & 5 & 1 & \\
\hline \multicolumn{4}{|l|}{ Após 20 Dias de Tratamento } \\
\hline Controle Negativo & 6 & 0 & \multirow{5}{*}{0,180} \\
\hline Controle Positivo & 3 & 3 & \\
\hline Miltefosina $200 \mathrm{mg}$ & 4 & 2 & \\
\hline TFD com ftalo & 4 & 2 & \\
\hline Miltefosina $200 \mathrm{mg}+$ TFD com ftalo & 6 & 0 & \\
\hline
\end{tabular}

Para o período de 20 dias após o término do tratamento, apesar das dificuldades em se encontrar o parasita no esfregaço de linfa, foi possível confirmar que $50 \%(3 / 6)$ dos animais do grupo controle positivo, ou seja, o grupo infectado e não tratado, apresentou positividade para o teste. Nos grupos miltefosina isolada e TFD com ftalocianina isolada, após o término do tratamento, foi possível observar com o teste de lâminas de extensão que cada grupo apresentou positividade de $33,3 \%(2 / 6)$, e o grupo de tratamento onde foi feita a associação Miltefosina $200 \mathrm{mg}$ + TFD com ftalocianina não foram encontrados parasitas fixados em nenhuma das lâminas.

\subsection{RESULTADO DA ANÁLISE DA QUANTIFICAÇÃO DE PARASITA POR PATA DOS CAMUNDONGOS}

A análise de diluição limitante foi realizada após os vinte dias de tratamento entre os cinco grupos (controle negativo, controle positivo (PBS), miltefosina, TFD com ftalocianina cloro-alumínio em formulação lipossomal, e miltefosina associada a TFD com ftalocianina cloro-alumínio em formulação lipossomal). O número de parasitas viáveis por pata foi determinada usando o software ELIDA. 


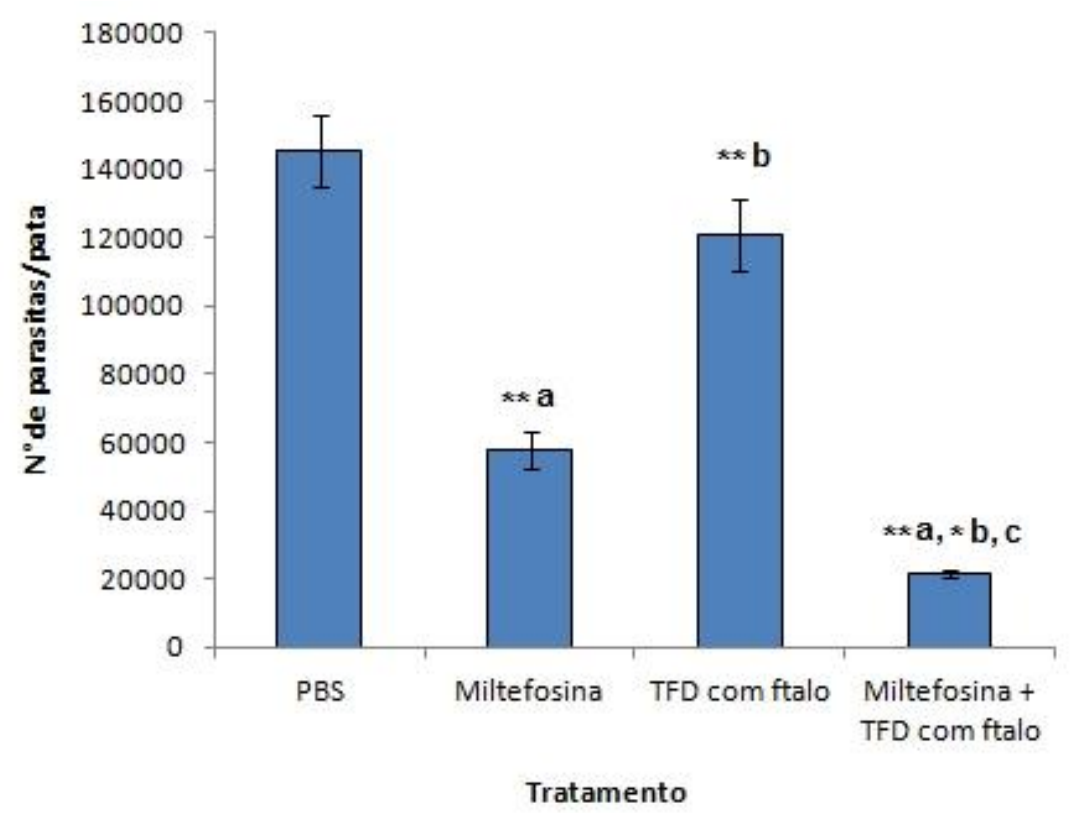

Gráfico 3: Distribuição do número de parasitas por pata de camundongo C57BL/6 infectados por Leishmania (L.) amazonensis.

Os dados correspondem à média e ao erro padrão da média (EPM). O número de parasitas viáveis por pata foi determinada utilizando-se o software ELIDA. As letras minúsculas indicam diferenças significativas detectadas pelo teste de Tukey nas comparações 2-a-2 (entre os grupos), sendo a= significativo comparado ao controle positivo (PBS); $b=$ significativo comparado ao grupo tratado com Miltefosina; $c=$ significativo comparado ao grupo tratado com terapia fotodinâmica com ftalocianina cloro-alumínio de formulação lipossomal. Os asteriscos indicam $\left({ }^{*} p<0,05\right)$ e $\left({ }^{* *} p<0,01\right)$.

O Gráfico 3 mostra que o tratamento com miltefosina associada à TFD com ftalocianina de cloro-alumínio em formulação lipossomal obteve resultados mais efetivos em seu potencial leishmanicida, quando comparados a todos os outros grupos do estudo. Entretanto, a associação isolada da TFD com ftalocianina de cloro-alumínio em formulação lipossomal não representou resultados significativos.

\subsection{RESULTADO DA ANÁLISE DE VIABILIDADE CELULAR}

Para o teste de viabilidade celular, os dados foram quantificados e normalizados tendo como base o controle negativo. A contagem do número de Leishmanias viáveis foi possível através da análise do teste de diluição limitante, permitindo a avaliação da distribuição da porcentagem de Leishmanias viáveis de acordo com cada grupo experimental testado neste estudo (Gráfico 4). 


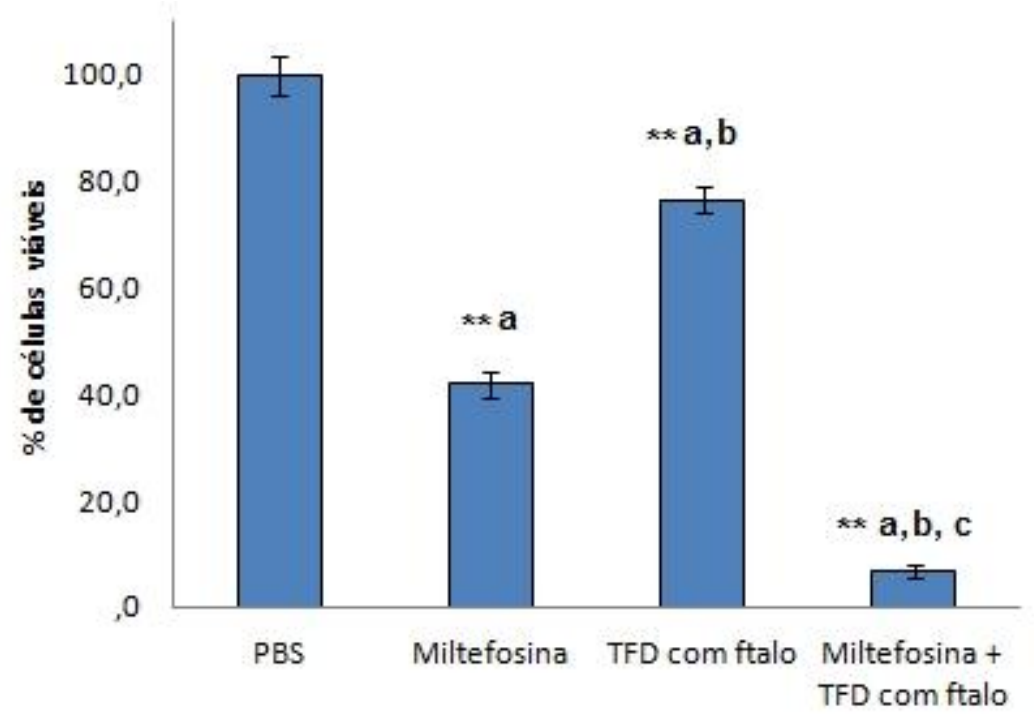

Tratamento

Gráfico 4: Distribuição do percentual de Leishmanias viáveis por pata de camundongos C57BL/6 infectados por Leishmania (L.) amazonensis.

Os dados correspondem à média e ao erro padrão da média (EPM). As letras minúsculas indicam diferenças significativas detectadas pelo teste de Mann-Whitney nas comparações 2-a2 (entre os grupos), sendo $a=$ significativo comparado ao controle positivo (PBS); $b=$ significativo comparado ao grupo tratado com miltefosina; $\mathrm{C}=$ significativo comparado ao grupo tratado com terapia fotodinâmica com ftalocianina cloro-alumínio de formulação lipossomal. Os asteriscos indicam diferenças altamente significativas $\left({ }^{* *} \mathrm{p}<0,01\right)$.

Conforme o Gráfico 4, observa-se que os três grupos em tratamento apresentaram redução do número de parasitas quando comparados ao controle positivo. O grupo que foi tratado com miltefosina $200 \mathrm{mg} / \mathrm{kg}$ dia apresentou expressiva redução da quantidade de parasitas por pata, o que já era esperado visto que o miltefosina já é um medicamento consagrado e provado com potencial leishmanicida. O grupo que utilizou apenas TFD com ftalocianina cloro-alumínio em formulação lipossomal não teve uma redução expressiva da quantidade de parasitas por pata. Já o grupo tratado com a associação de miltefosina $200 \mathrm{mg} / \mathrm{kg}$ dia e sua associação com a TFD, com ftalocianina de cloro alumínio em formulação lipossomal, foi o grupo com maior eficácia dentre os três testados neste estudo. Esta associação apresentou maior eficácia que o tratamento considerado como padrão ouro que utiliza apenas a miltefosina de forma sistêmica. 


\section{DISCUSSÃO}

Os tratamentos farmacológicos para a leishmaniose ainda não têm apresentado resultados clínicos desejáveis por causa de sua baixa eficácia, toxidade e resistência às drogas (CARVALHO, 2011). Por outro lado, a vacina para este mal ainda é inexistente. Tais considerações aliadas à necessidade de novas alternativas terapêuticas justificam os esforços e estudos que objetivam o tratamento da leishmaniose. A OMS, por sua vez, recomenda pesquisas com métodos de manipulação de novos fármacos e formulações, segurança nas vias de administração, sejam oral ou tópica (WHO, 2010).

Segundo Barcellos (2013), a utilização de terapias tópicas para o tratamento contra a leishmaniose tem sido eficaz no controle de lesões, com a utilização, por exemplo, de indução de calor via rádio frequência para remissão de lesões cutâneas. Essa técnica já foi testada, demonstrando eficiência no tratamento de humanos. Em cães, a mesma técnica foi experimentada, observando-se regressão completa da lesão em 45 dias, sem recidiva durante 16 meses.

Bem Salah et al. (2009) também utilizaram terapias medicamentosas tópicas. No caso deles, a formulação envolveu paramomicina e gentamicina em base hidrofílica, com $94 \%$ de cura no grupo tratado e sem recidiva nos seis meses após o tratamento.

Percebe-se uma tendência e indicações descritas em diversos trabalhos de que a terapia tópica pode ser bastante efetiva para o tratamento contra a leishmaniose. Suri et al. (2007) acreditam que as drogas nanoestruturadas, como a ftalocianina de cloro-alumínio em formulação lipossomal utilizada neste estudo, sejam mais eficazes que as terapias tradicionais na eliminação de microorganismos patogênicos, sem liberar diretamente mediadores químicos. A importância da ftalocianina também foi destacada por Escobar et al. (2006), em experimento in vivo, quando a apontaram como ideais à TFD, pois é eficientemente incorporada nas células alvo, não é tóxica para as células saudáveis, e apresenta alto rendimento de produção de estados tripleto. 
A ftalocianina cloro-alumínio foi microencapsulada dentro de lipossomas, com o objetivo de se alcançar uma maior absorção na pele das moléculas. O presente estudo, em consonância aos supracitados, segue a tendência de experimentação de fórmulas tópicas nanoestruturadas para o tratamento contra a LC, envolvendo associação do manipulado tópico de ftalocianina cloro-alumínio em formulação lipossomal. Tal associação exerceu papel fundamental na resposta ao tratamento contra o parasita Leishmania (L.) amazonensis, causador da LC, resultado este que pode ser observado quando há a comparação do grupo tratado apenas com miltefosina e o grupo que associou miltefosina e TFD ftalocianina tópica. Ainda que este estudo não tivesse o objetivo de avaliar os efeitos adversos, o tratamento com associação tópica da ftalocianina com miltefosina resultou em redução mais significativa de parasitas no local da lesão, bem como a diminuição da viabilidade celular. Esses resultados podem servir como base para trabalhos futuros, onde os efeitos adversos de tal tratamento possam ser investigados mais profundamente.

Em revisão bibliográfica realizada até setembro de 2014, encontraram-se poucos estudos que relatassem experimentos leishmanicidas, associando a TFD com ftalocianinas de cloro-alumínio, como o de Carneiro (2013), em que os resultados obtidos a partir do tratamento tópico, in vivo, com ftalocianina de cloroalumínio em formulação lipossomal superaram 0 atual esquema terapêutico preconizado pela OMS para o tratamento contra o parasita da Leishmania (L.) amazonensis. A OMS preconiza que o tratamento de primeira escolha contra a leishmaniose seja o que utiliza o antimonial pentavalente em um período de 20 dias $20 \mathrm{mgSb} / \mathrm{kg} / \mathrm{dia}$ (WHO, 2010).

Para este estudo, foram experimentados métodos in vivo, utilizando o parasita do gênero e espécie Leishmania (L.) amazonensis, necessitando de avaliação para outras espécies e gêneros do parasita da leishmaniose. Evidenciou-se que, para uma análise mais formativa e para gerar resultados que permitam comparações e análises ainda mais íntegras, sejam realizados ensaios in vitro com mais de uma espécie de Leishmania e com maior número de animais in vivo, a exemplo do trabalho de Escobar et al. (2006) onde foram utilizadas formulações de Cloreto de Alumínio Ftalocianina (ALPC) e Ftalocianina de Zinco ( $\mathrm{ZnPc}$ ), após a iluminação de luz infravermelha, para inibição das espécies Leishmania chagasi e Leishmania 
panamensis. No mesmo estudo, os autores sugeriram a repetição do experimento testando a fotoatividade dos compostos em amastigotas axênicos ou intracelulares em modelos animais.

Apesar de a droga de primeira escolha para o tratamento contra a leishmaniose ser o antimoniato de N-metil glucamina, estudos realizados em 21 pacientes do Hospital Universitário de Brasília (SILVA, 2011) demonstram que o tratamento da leishmaniose com miltefosina mostrou-se tão eficaz quanto 0 tratamento padrão com a glucamina, com a vantagem de ser menos tóxico e proporcionar a cura das lesões em menor período de tempo. Em outro estudo, realizado em camundongos, a miltefosina oral apresentou eficácia semelhante, senão maior que o N-metil glucamina para o tratamento contra o parasita Leishmania (L.) amazonensis (COSTA FILHO; LUCAS; SAMPAIO, 2008). Para este estudo, optou-se então em utilizar a associação da ftalocianina cloro-alumíno em formulação lipossomal à miltefosina, porque esta última apresenta vantagens em sua administração por via oral, favorece adesão ao tratamento, é mais conveniente ao paciente, e tem se mostrado uma opção terapêutica segura, economicamente viável e eficaz aos refratários aos $\mathrm{Sb}^{\mathrm{V}}$ (SILVA, 2011). O autor ainda relata que a miltefosina "possibilita uma diminuição indireta dos custos de tratamento, uma vez que requer um menor número de visitas aos serviços médicos e menos gastos com materiais de consumo e exames laboratoriais".

Sobre o índice de polidispersão da ftalocianina de cloro-alumínio em formulação lipossomal, este indicou pouca homogeneidade de dispersão. Sendo assim, ainda é preciso investigar este ponto, pois indica baixa estabilidade. Alguns fatores podem estar envolvidos, tais como a adição de compostos (alumínio, ftalocianina, etc). Ainda sobre a caracterização dos lipossomas contendo ftalocianina de cloro alumínio, ressalta-se que foram encontrados fragmentos de alumínio na superfície dos lipossomas. O hidróxido de alumínio é um dos adjuvantes mais utilizados em vacinas para humanos e veterinários (SILVA et al., 2004), pois induz 0 aumento na migração macrofágica e neutrofílica para o sítio de inoculação (RESENDE et al., 2004), o que é positivo, pois pode auxiliar no tratamento local da lesão causada pela leishmaniose. Logo, pode ser considerado que o alumínio pode ter contribuído para a eficácia do resultado deste estudo. 
O primeiro teste deste estudo utilizou como critério a medição do diâmetro das patas dos camundongos, para avaliar a regressão ou não da lesão, e resultou em tratamento efetivo contra o parasita Leishmania (L) amazonensis, quando realizou-se a associação da miltefosina e TFD com ftalocianina de cloro-alumínio em formulação lipossomal. Portanto, houve regressão maior da lesão das patas dos camundongos deste grupo em comparação aos grupos que foram tratados isoladamente com mitefosina ou TFD com ftalocianina. Neste grupo, o diâmetro das patas mais se aproximou ao do grupo controle negativo, onde os animais possuíam o diâmetro das patas sem o processo patológico, causado pelo parasita da Leishmania (L) amazonensis. Corroborando com esta observação, o experimento de Carneiro (2013), que também utilizou formulação lipossomal ftalocianina de cloroalumínio, apresentou regressão do diâmetro da pata dos animais que receberam tratamento com ftalocianina tópica.

Os resultados das culturas confirmam os resultados supracitados, onde 0 grupo que associou miltefosina e TFD com ftalocianina de formulação lipossomal, superando a resposta contra o parasita, quando comparados aos dados do grupo tratado com miltefosina utilizada isoladamente.

O teste de confecção de lâminas de extensão apresentou pouca sensibilidade para a detecção dos parasitas fixados e corados nas lâminas. Estes resultados podem não representar muita fidedignidade em decorrência da quantidade de animais (n) e a sensibilidade do teste ser muito pequena. Entretanto, os resultados apresentados para o teste de lâmina de extensão corroboram com os outros testes realizados neste estudo, visto que o grupo que melhor apresentou eficácia após os 20 dias de tratamento foi o grupo onde foi feita a associação miltefosina $200 \mathrm{mg}+$ TFD com ftalocianina. Este resultado demonstra que a TFD com ftalocianina possui potencial leishmanicida.

O teste de quantificação de parasita por pata dos camundongos feito com o software Elida, que também avalia a eficácia do tratamento entre os grupos, demonstrou que houve maior eficácia do grupo tratado com a associação de miltefosina e TFD com ftalocianina de cloro-alumínio em formulação lipossomal. Os resultados superam os do grupo tratado com miltefosina isoladamente. Isso torna seguro afirmar que a associação do tratamento oral com miltefosina e TFD com 
ftalocianina de cloro-alumínio em formulação lipossomal tópica potencializa a ação leishmanicida do tratamento, pois o grupo que mais se aproximou ao grupo controle negativo no quesito presença de parasita por pata foi onde realizou-se a associação das drogas. Testes realizados por Carneiro (2013), que também objetivou a avaliação da quantidade de parasitas por pata por meio do método de diminuição limitante, demonstraram que os tratamentos com TFD com ftalocianina cloroalumínio in vivo reduziram consideravelmente os parasitos da espécie Leishmania (L.) amazonensis, e não houve diferença estatística entre os resultados do grupo tratado com ftalocianina cloro-alumínio isoladamente e o grupo tratado com antimonial pentavalente.

O quinto e último teste que avaliou a viabilidade celular entre os grupos tratados também demonstrou que, dentre os três grupos que receberam tratamento, o grupo onde foi feita a associação miltefosina e TFD com ftalocianina de cloroalumínio em formulação lipossomal apresentou resultados que superaram os do grupo tratado com miltefosina isoladamente e TFD com ftalocianina de cloroalumínio em formulação lipossomal isoladamente. Tal constatação vai ao encontro, por exemplo, ao relato de Perussi (2007), quando a utilização de ftalocianina em quimioterapia fotodinâmica mostrou-se eficaz, por possuir características necessárias para promover eficientemente a redução da viabilidade celular maior do que um FS padrão.

Diante dos cinco testes realizados neste estudo (medição das patas, culturas, lâminas de extensão, número de parasita por pata e viabilidade celular), pôde-se, portanto, verificar que houve maior eficácia para o grupo que foi tratado com a associação de TFD com ftalocianina de cloro-alumínio em formulação lipossomal e miltefosina $200 \mathrm{mg} / \mathrm{kg} / \mathrm{dia}$, superando, assim, os resultados dos demais grupos deste experimento. Ressalta-se ainda que os cinco testes realizados apresentaram resultados significantes, no que se refere à eficácia do tratamento contra o parasita da Leishmania (L.) amazonensis. Porém, para Bastos et al. (2012), os dados ainda são limitados porque não avaliam a toxidade in vivo e assim a TFD não pode ser recomendada na prática clínica de rotina. Além disso, o mecanismo de ação desta promissora modalidade terapêutica também precisa ser mais bem investigada. 
Estes achados podem ser bastante positivos para 0 atual cenário de tratamentos contra os parasitas causadores das formas cutâneas de leishmaniose, visto que os atuais medicamentos utilizados apresentam altos índices de resistência e toxidade (CARVALHO, 2011), necessitando de associações para tornar o tratamento mais efetivo. É importante relatar que o número de animais utilizados neste estudo é pequeno ( 6 animais), porque foi a quantidade definida pelo CEUA, requerendo estudos posteriores, com quantidade maior de animais, possibilitando ampliar as possibilidades de testes, incrementando, assim, a precisão dos resultados.

Conhecidos os resultados do presente estudo, onde optou-se por realizar o experimento apenas com a lesão, seria conveniente ensaios in vivo cuja metodologia previsse a aplicação de TFD com ftalocianina cloro-alumínio em formulação lipossomal em animais com presença de lesão ulcerada, como sugeriram Ospina et al. (2014). Segundo os autores, a aplicação de ftalocianina na lesão, apesar de ser mais tóxica, apresenta um potencial antiparasitário ainda maior porque ocorre maior absorção na lesão ulcerada.

\section{CONCLUSÃO}

O tratamento de camundongos infectados com LC causada pela espécie e gênero do tipo Leishmania (L.) amazonensis e tratados com a associação de miltefosina oral $200 \mathrm{mg} / \mathrm{kg} /$ dia e terapia fotodinâmica mediada por ftalocianina de cloro-alumínio em formulação lipossomal tópica causou maiores reduções do número de parasitas e da viabilidade celular quando comparado com o grupo que foi tratado apenas com miltefosina oral $200 \mathrm{mg} / \mathrm{kg} / \mathrm{dia}$, considerado o tratamento padrão-ouro contra a leishmaniose. Assim sendo, é relevante dizer que a associação de miltefosina oral com TFD com ftalocianina de cloro alumínio em formulação lipossomal pode representar uma possibilidade terapêutica eficiente diante do atual cenário de possibilidades para o tratamento de LC. Essa eficiência pode ser resultado de uma possível diminuição da quantidade da droga sistêmica e pela forma de administração da miltefosina, dispensando internação do paciente.

O presente trabalho visou contribuir positivamente com resultados de um experimento que represente uma terapia alternativa que, quando associada aos 
atuais tratamentos, pode trazer melhorias do quadro de LC em animais e pacientes que desenvolveram a LC. Assim sendo, estes resultados apresentados e a metodologia empregada podem servir como base para o aprimoramento e novas pesquisas desenvolvidas por profissionais de áreas afins que desejam contribuir para a descoberta de uma forma mais eficaz de tratamento contra as formas cutâneas de leishmanioses.

\section{PERSPECTIVAS}

Apesar dos resultados positivos apresentados por este estudo experimental, espera-se que sejam realizados futuramente novos estudos que tenham por objetivo ampliar, avaliar e confirmar os atuais achados.

A associação da TFD com ftalocianina de cloro-alumínio em formulação lipossomal pode propiciar melhoras nos efeitos adversos causados pelos atuais tratamentos contra o parasito das leishmanioses cutâneas. Esta associação pode resultar inclusive em redução das doses dos medicamentos atualmente utilizados.

Espera-se também que sejam realizados testes que avaliem a eficácia deste tratamento para outras espécies do parasita, como por exemplo a Leishmania (V.) braziliensis e Leishmania (V.) guyanensis, espécies predominantes no Brasil.

Pode ser feita ainda a modificação da atual metodologia que utiliza a aplicação tópica da ftalocianina de cloro-alumínio em formulação lipossomal para a aplicação injetável, com o objetivo de avaliar se a via de administração injetável pode melhorar ainda mais os resultados.

Além da avaliação da eficácia deste tratamento, existe a necessidade de outros testes que avaliem a toxidade sistêmica antes da fase clínica.

A realização da mesma metodologia utilizada neste estudo experimentando outros medicamentos - como os antimoniais pentavalente e trivalente - pode ser outro fator relevante, visto que os antimoniais são as drogas de primeira escolha no Brasil para o tratamento das leishmanioses. 
Uma vez observado o resultado positivo deste experimento, cabe, ainda, a realização de testes utilizando outras famílias e formulações de manipulados de drogas fotossensíveis, como porfirinas, clorinas, e outras formulações de ftalocianinas.

Sobre o índice de polidispersão do lipossoma da ftalocianina de cloroalumínio, é preciso investigar se a pouca homogeneidade de dispersão encontrada está associada à técnica utilizada para a realização da avaliação, ou se isto está associado à adição dos compostos alumínio e cloro. Futuros trabalhos podem avaliar se uma maior estabilidade da droga fotoativa pode potencializar os seus efeitos terapêuticos.

\section{REFERÊNCIAS}

ALISSON, R. R.; DOWNIE, G. H.; CUENCA, R.; HU, X. H.; CHILDS, C. J. H.; SIBATA, C. H. Photosensitizers in clinical PDT. Photodiagnosis and Photodynamic Therapy, v.1, n.1, p.27-42, 2004.

ALMEIDA, O. L. S. Avanços no tratamento da leishmaniose tegumentar do novo mundo nos últimos dez anos: uma revisão sistemática da literatura. Anais Brasileiros de Dermatologia. v.86, n.3, p.497-506, 2011.

BALLAND, O. et al. Intracellular distribution of ampicillin in murine macrophages infected with Salmonella typhimurium and treated with $(3 \mathrm{H})$ ampicillin-loaded nanoparticles. Journal of Antimicrobial Chemotherapy.v.37, n.1, p.105-115, 1996.

BARBOSA, V. T.; SILVA, M. A. G.; SOUSA, M. G.; GERING, A. P.; SANTOS, H. D.; LAUS, J. L. Detecção de formas amastigotas em exame parasitológico de esfregaço obtido a partir de suabe conjuntival de cães com leishmaniose visceral. Arquivo Brasileiro de Medicina Veterinária e Zootecnia, v.64, n.6, p.1465-1470, 2012.

BARCELLOS, M. P. Uso da furazolidona no tratamento clínico de cães com leishmaniose tegumentar americana. [Dissertação de Mestrado]. Ciências Veterinárias. Universidade Federal do Espírito Santo, Centro de Vivências Agrárias. 77f. Espírito Santo, 2013.

BARRAL-NETTO M. et al. Recent Advances in the Pathophysiology and Treatment of Human Cutaneous Leishmaniasis. Current Opinion in Dermatology, v.4, p.5158, 1997.

BASANO, S. de A.; CAMARGO, L. M. A. Leishmaniose tegumentar americana: histórico, epidemiologia e perspectivas de controle. Revista Brasileira de Epidemiologia. v.7, n.3. São Paulo, 2004. 
BASTOS, M. M. et al. O uso de Porfirinas em Terapia Fotodinâmica no Tratamento da Leishmaniose Cutânea, Revista Virtual de Química, v.4, n.3, p.257-267, 2012.

BASTOS, J. L. N. et al. Análise da ação da quimioterapia fotodinâmica antimicrobiana (PACT) com ftalocianina cloro-alumínio (FC-C1A1) sobre os microrganismos Pseudomonas aeruginosa (Gram-) e Staphylococcus aureus (Gram+). Brazilian Journal of Biomedical Engineering. 2013.

BEN SALAH, A. et al. WR279,396, a third generation aminoglycoside ointment for the treatment of Leishmania major cutaneous Leishmaniasis: a phase 2, randomized, double blind, placebo controlled study (tropical treatment of cutaneous

Leishmaniasis). PLoS Neglected Tropical Diseases, San Francisco, v.3, n.5, 2009.

BERGSTRAND, N. et al. Interactions between pH-sensitive liposomes and model membranes. Biophysical Chemistry. v.104, p.361-379, 2003.

BRAJTBURG, J; BOLARD, J. Carrier effects on biological activity of amphotericin B. Clinical Microbiology Reviews. n.9, p.512-531, 1996.

BRASIL. Ministério da Saúde. Secretaria de Vigilância em Saúde. Manual de recomendações para diagnóstico, tratamento e acompanhamento de pacientes com coinfecção Leishmania-HIV, 106p. 2011

. Ministério da Saúde. Manual de Controle da Leishmaniose Tegumentar Americana. Brasília, 2000.

. Ministério da Saúde. Secretaria de Vigilância em Saúde. Manual de

Vigilância da Leishmaniose Tegumentar Americana. 2.ed. Brasília: Ministério da Saúde, 2010.

CARNEIRO, A. L. Uso de terapia fotodinâmica com ftalocianina cloro alumínio no tratamento tópico da leishmaniose cutânea. Dissertação (mestrado). Universidade de Brasília. Brasília: Departamento de Ciências Médicas, 2013.

CARVALHO, R. F. De. Estudo in vivo da ação de nanocápsulas de PLGA contendo anfotericina $\mathrm{B}, \mathrm{DMSA}$ e nanopartículas magnéticas no tratamento da leishmaniose cutânea experimental em camundongos C57BL/6 causada pela Leishmania (Leishmania) amazonensis. 2011. 72 f. Dissertação (Mestrado) Curso de Ciências Médicas, Departamento de Faculdade de Ciências Médicas, Universidade de Brasília, Brasília, 2011.

CHANG, K. P. el al. Leishmania model for microbial virulence: the relevance of parasite multiplication and pathoantigenicity. Acta Tropica. v.85, n.3, 2003, p.375390.

CHEDGZOY, P.; WINCKLE, G.; HEARD, C. M. Triclosan: release from transdermal adhesive formulations and in vitro permeation across human epidermal membranes. International Journal of Pharmaceutics. Amsterdam, v.235, p.229-236, 2002. 
CHRUSCIAK-TALHARI, A. et al. Randomized controlled clincial Trial to Access efficacy and safety of Miltefosina in the treatment of cutaneous Leishmaniasis caused by Leishmaniasis (Viannia) guyanensis in Manaus, Brazil. The American Journal of Tropical Medicine and Hygiene, v.84, n.2, p.255, 2011.

CLEMENTS, J. S. et al. Amphotericin B revisited: reassessment of toxicity. American Journal of Medicine. n.88, 1990, p.22n-27n.

COSTA FILHO, A. V. da; LUCAS, I. C.; SAMPAIO, R. N. R. Estudo comparativo entre miltefosina oral e antimoniato de $\mathrm{N}$-metl glucamina parenteral no tratamento da leishmaniose experimental causada por Leishmania (Leishmania) amazonensis. Revista da Sociedade Brasileira de Medicina Tropical. v.41, n.4, p.424-427, 2008.

DESJEUX P. The increase in risk factors for Leishmaniasis worldwide. Transactions of the Royal Society of Tropical Medicine and Hygiene. v.95, n.3, p.239-243, 2001.

DOMINGOS, I. H.. Teste rápido TR-DPP(R) no contexto do diagnóstico sorológico da leishmaniose visceral canina. 2012. 64 f. Dissertação (Mestrado) Curso de Saúde Animal, Departamento de Pós-graduação em Ciência Animal, Universidade Federal de Mato de Grosso do Sul, Mato Grosso do Sul, 2012. . Leishmaniasis: current situation and new perspectives. Comparative Immunology, Microbiology and Infectious Disease. v.27, 2004, p.305-318.

DOUGHERTY, T. J.; GOMER, C. J.; HENDERSON, B. W.; JORI, G.; KESSEL, D.; KOBERLIK, M.; MOAN, J.; PENG, Q. Photodynamic Therapy. Journal National Cancer Institute, v.90, n.12, p.889-905, 1998.

GONTIJO, B.; CARVALHO, M. L. R. Leishmaniose tegumentar americana. Revista da Sociedade Brasileira de Medicina Tropical. v.36, n.1, p.71-80, jan-fev, 2003.

HENDERSON, B. W.; DOUGHERTY, T. J. How does photodynamic therapy work? Photochemistry and Photobiology. v.55, n.1 ,p.145-157, 1992.

ESCOBAR, P. et al. Photodynamic activity of aluminium (III) and zinc (II) phthalocyanines in Leishmania promastigotes. Biomédica. v.26, n.1, Bogotá, oct. 2006.

FAROKHZAD, O. C.; LANGER, R. Impact of Nanotechnology on Drug Delivery. ACS Nano. v.3, n.1, p.16-20, 2009.

FISCHER, A. M. R. et al. Clinical and preclinical photodynamic therapy. Lasers in Surgery and Medicine. v.17, n.1, 1995.

FREZARD, F. C. et al. Pentavalent antimonials: new perspectives for old drugs. Molecules. n.14, 2009, p.2317-2336. 
GARNIER T.; CROFT S. L. Topical treatment for cutaneous Leishmaniasis. Current Opinion in Investigational Drugs, v.3, n.4, 2002.

GOTO, H.; LINDOSO, J. A. L. Current diagnosis and treatment of cutaneous and mucocutaneous Leishmaniasis. Expert Review of Anti Infective Therapy. v.8, n.4, 2010, p.419-433.

HOPPER, C.et al. The cost-effectiveness of Foscan mediated photodynamic therapy (Foscan-PDT) compared with extensive palliative surgery and palliative chemotherapy for patients with advanced head and neck cancer in the UK. Oral Oncology, v. 40, n. 4, p. 372-382, 2004.

LASIC, D.D. Novel application of liposomes. Trends Biotechnology., Amsterdam, v.16, p.307-321, 1998.

LONGO, J. P. F.. Avaliação da aplicação da Terapia Fotodinâmica mediada pela Alumínio-Cloro-Ftalocianina em formulação lipossomal sobre o câncer bucal em modelos experimentais in vivo e in vitro. 2008. $81 \mathrm{f}$. Dissertação (Mestrado) Curso de Faculdade de Medicina, Departamento de Pós Graduação em Patologia Molecular, Universidade de Brasília, Brasília, 2008.

MACHADO, P. R. et al. Miltefosina in the Treatment of Cutaneous Leishmaniais caused by Leishmania braziliensis in Brazil: a randomized and controlled trial (Miltefosina for L. braziliensis CL). PLoS Neglected Tropical Diseases, San Francisco, v.4, n.12, 2010.

MOGHIMI, S. M. et al. Nanomedicine: current status and future prospects. The FASEB Journal., v.19, p.311-330, 2005.

KLAUS S. N. et al. Epidemiology of cutaneous Leishmaniasis. Clinical Dermatology. v.17, n.3, p.257-260, 1999.

OLIVEIRA, L. F. et al. Systematic review of the adverse effects of cutaneous Leishmaniasis treatment in the New World. Acta Tropica, v.118, n.2, p.87-96, 2011.

OLIVEIRA, D. M.; LACAVA, Z. G.; LIMA, E. C.; MORAIS, P. C.; TEDESCO, A. C. Zinc phthalocyanine/magnetic fluid complex: a promising dual nanostructured system for cancer treatment. Journal Nanoscience Nanotechnology, v.6, n.8, p.24322437, 2006.

OSPINA, V. E. et al. Permeación em piel humana de una nanoemulsión de ftalocianina de aluminio clorada para La optimización de tratamientos tópicos de leishmaniasis cutânea. Revista Ciencias Salud, v.12, n.23, Bogotá, 2014.

OTA, H. et al., Pretreatment of macrophages with the combination of IFN-gamma and IL-12 induces resistance to Leishmania major at the early phase of infection. $\mathbf{J}$ Veterinary Medical Science. n.70, v.6, 2008, p.589-593.

PARIS, C. et al. Miltefosina induces apoptosis-like death in Leishmania donovani promastigotes. Antimicrobial Agents and Chemotherapy. n.48, 2004, p.852-859. 
PEÑARANDA, I. P. H.. Actividad fototóxica in vitro e in vivo de ftalocianina de aluminio clorada contra Leishmania amazonensis.2010. 110 f. Dissertação (Mestrado) - Curso de Ciências Básicas Biomédicas, Departamento de Facultad de Salud, Universidad Industrial de Santander, Bucaramanga, 2010.

PEREIRA, L. I. de A. Avaliação dos monócitos na Leishmaniose Tegumentar Americana. Tese (doutorado). Universidade Federal de Goiás, Instituto de Patologia Tropical e Saúde Pública, 2012.

PIMENTEL, L. F. et al. Nanotecnologia farmacêutica aplicada ao tratamento da malária. Revista Brasileira de Ciências Farmacêuticas. v.43, n.4, out./dez., 2007.

PONTES, A.C.O.; CAETANO, M.N.P.; SANTOS-MAGALHÃES, N.S.

Physicochemical characterization and antimicrobial activity of benzathine penicillin $G$ liposomes. S.T.P. Pharma Science., Paris, v.9, p.419-427, 1999.

PEREZ-VICTORIA, F. J. et al. Mechanisms of experimental resistance of Leishmania to Miltefosina: Implication for clinical use. Drug Resistance Updates. n.9, 2006, p.26-39.

PERUSSI, J. R. Inativação fotodinâmica de microrganismos, Química Nova, v.30, n.4, p.1-7, 2007.

RABÊLO, J. M. M. Flebótomos vetores das leishmanioses (Manual para técnicos e profissionais de saúde). São Luís: Universidade Federal do Maranhão, 1999.

RAMOS, C. S. et al.. Leishmania amazonensis META2 protein confers protection against heat shock and oxidative stress. Experimental Parasitology. n.127, v.1, 2011, p.228-237.

RESENDE, F. C. B. et al. Adjuvantes de vacinas: possibilidades de uso em seres humanos ou animais. Revista Brasileira de Alergia e Imunopatologia. v.27, n.3, 2004, p.116-124.

RODRIGUES, L. F. Avaliação da atividade in vivo do antimoniato de meglumina e de sua associação com o tratamento tópico sobre Leishmania (Viannia) braziliensis isoladas de pacientes portadores de leishmaniose cutânea. [Dissertação de Mestrado]. Ciências da Saúde. Fundação Oswaldo Cruz, Belo Horizonte, 2012.

RODRIGUEZ, M. E. et al. A randomized trial of amphotericin B alone or in combination with itraconazole in the treatment of mucocutaneous Leishmaniasis. Memórias do Instituto Oswaldo Cruz. n.90, 1995, p.525-528.

ROJAS R. et al. Resistance to antimony and treatment failure in human Leishmania (Viannia) infection. Jounal of Infectious Diseases, v.193, p.1375-1383, 2006.

SAMPAIO, R. N. et al. The evaluation of the tolerance and nephrotoxicity of pentavalent antimony administered in a dose of $40 \mathrm{mg} \mathrm{Sb} \mathrm{V/Kg/day,} \mathrm{12/12hr,} \mathrm{for} 30$ 
days in the mucocutaneous form of Leishmaniasis. Revista Sociedade Brasileira Medicina Tropical. n.30, 1997, p.457-463.

SEIFERT, K. et al. Effects of Miltefosina and other alkylphosphocholines on human intestinal parasite Entamoeba histolytica. Antimicrobial Agents and Chemotherapy. n.45, 2001, p.1505-1510.

SERENO, D. P. et al. Antimonial-mediated DNA fragmentation in Leishmania infantum amastigotes. Antimicrobial Agents and Chemotherapy. N.45, 2001, p.2064-2069.

SILVA, G.A. Introduction to nanotechnology and its applications to medicine. Surgical Neurology. , Amsterdam, v.61, p.216-220, 2004.

SILVA, J. S. F. Ensaio Clínio do Miltefosine no Tratamento de Pacientes com Leishmaniose Mucosa. Dissertação de Mestrado. Ciências Médicas. Universidade de Brasília, 104f., 2011.

SILVA, L. C. et al. Avaliação da capacidade adjuvante do cloreto de dimetildioctadecilamônio associado ao hidróxido de alumínio na indução da resposta imune humoral de bovinos vacinados com o vírus da diarreia viral bovina. Brazilian Journal of Veterinary Research and Animal Science. v.41, 2004, p.201-206.

SILVEIRA, F. T. Patogenia da leishmaniose tegumentar americana:

caracterização clínica, histopatológica e imunológica da leishmaniose disseminada, com ênfase na Leishmania (L.) amazonensis. Tese (doutorado). São Paulo:

Faculdade de Medicina. Universidade de São Paulo, 2001.

SINGH, S.; SIVAKUMAR, R. Challenges and new discorevies in the treatment of Leishmaniasis. Journal of Infection and Chemotherapy. v.10, p.307-315, 2004.

SUNDAR, S. Drug resistance in Indian visceral Leishmaniasis. Tropical Medicine and International Health. n.6, 2001. P.849-854.

SURI, S. S.; FENNIRI, H.; SINGH, B. Nanotechnology-based drug delivery systems. Journal of Occupational Medicine and Toxicology., v.2, 2007.

TUON, F. F. et al. Treatment of New World cutaneous Leishmaniasis-a systematic review with a meta-analysis. International Journal of Dermatology, n.47, 2008, p.109-124.

URDAPILLETA, A. A. A. Atividade de substâncias isoladas de liquens sobre formas promastigotas de Leishmania (L.) amazonensis e Leishmania (V.) braziliensis. [Dissertação Mestrado]. Ciências da Saúde, Universidade de Brasília, Brasília, 2006, p.87.

VÉLEZ, I. et. al. Efficacy of Miltefosina for the treatment of American cutaneous Leishmaniasis. The American Journal of Tropical Medicine and Hygiene, v.83, v.2, 2010. 
VIANNIA, G. Sobre uma espécie de Leishmania. Brasil Médico. v.25, 1912.

World Health Organization. Control of the Leishmaniases. Report of a WHO Expert Committee Technical Report Series, 2010. 


\section{ANEXOS}

1. APROVAÇÃO COMITÊ DE ÉTICA

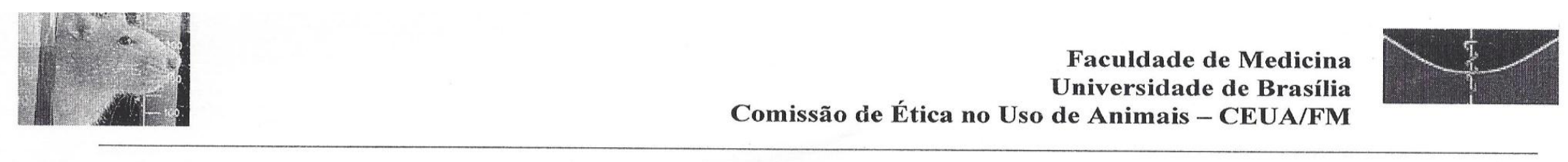

Brasília, 01 de agosto de 2012

\section{DECLARAÇÃo}

Declaramos que o projeto intitulado "Avaliação in vivo da efetividade quanto à resposta ao tratamento contra o parasita Leishmania (L) amazonenses, por meio da utilização das drogas sistêmicas miltefosine e antimoniato de n-metilglucamina associadas à terapia fotodinâmica com ftalocianina cloro-alumínio", UnBDoc 83795/2012, sob responsabilidade da Raimunda Nonata Ribeiro Sampaio, foi avaliado e aprovado pela Comissão de Ética no Uso de Animais (CEUA-FM) da Faculdade de Medicina da Universidade de Brasília.

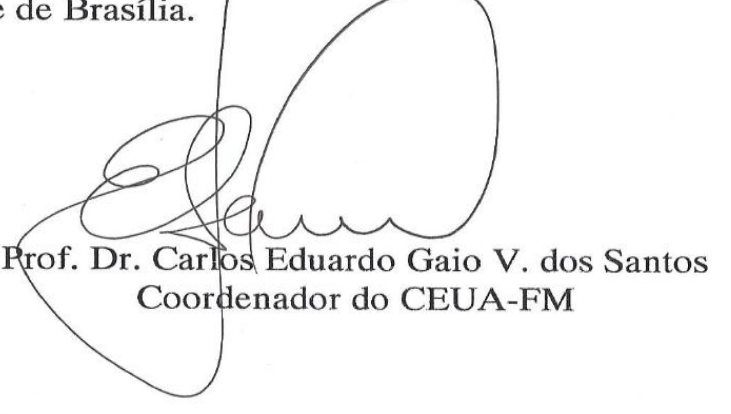




\section{TESTE DE NORMALIDADE DOS DADOS DAS MEDIDAS DO PAQUÍMETRO}

\begin{tabular}{|c|c|c|c|c|c|c|c|}
\hline & & Kolmc & ov-Smir & & & piro-Wilk & \\
\hline & Grupo & Statistic & df & Sig. & Statistic & df & Sig. \\
\hline Antes de infectar & controle negativo & ,293 & 6 & ,117 & ,822 & 6 &, 091 \\
\hline & controle positivo & ,392 & 6 & ,004 & 701 & 6 & ,006 \\
\hline & $\begin{array}{l}\text { Miltefosina. } 20 \\
\text { mg + TFD com } \\
\text { ftalo }\end{array}$ & 183 & 6 &, $200\left(^{*}\right)$ & 960 & 6 & 820 \\
\hline & Miltefosina & 392 & 6 & 004 & 701 & 6 & ,006 \\
\hline & TFD com ftalo & ,392 & 6 & ,004 & 701 & 6 & ,006 \\
\hline 02 dias após a & controle negativo & ,492 & 6 &, 000 & ,496 & 6 &, 000 \\
\hline & controle positivo & ,293 & 6 & , 117 & ,822 & 6 & 091 \\
\hline & $\begin{array}{l}\text { Miltefosina. } 20 \\
\text { mg + TFD com } \\
\text { ftalo }\end{array}$ & 293 & 6 & 117 & 915 & 6 & 473 \\
\hline & Miltefosina & 392 & 6 & ,004 & 701 & 6 & ,006 \\
\hline & TFD com ftalo & 254 & 6 &, $200\left(^{*}\right)$ & 866 & 6 & 212 \\
\hline 30 dias após a & controle negativo & ,254 & 6 & ,200(*) & ,866 & 6 & ,212 \\
\hline & controle positivo & ,333 & 6 & ,036 & 827 & 6 & 101 \\
\hline & $\begin{array}{l}\text { Miltefosina. } 20 \\
\text { mg + TFD com } \\
\text { ftalo }\end{array}$ & 183 & 6 &, $200\left(^{*}\right)$ & 960 & 6 & 820 \\
\hline & Miltefosina & ,254 & 6 &, $200\left(^{*}\right)$ & ,866 & 6 & ,212 \\
\hline & TFD com ftalo & 293 & 6 & 117 & 822 & 6 & ,091 \\
\hline Após 20 dias de & controle negativo & ,319 & 6 & ,056 & ,683 & 6 & 004 \\
\hline & controle positivo & 293 & 6 & 117 & 822 & 6 & ,091 \\
\hline & $\begin{array}{l}\text { Miltefosina. } 20 \\
\text { mg + TFD com } \\
\text { ftalo }\end{array}$ & 407 & 6 & 002 & 640 & 6 & ,001 \\
\hline & Miltefosina & 202 & 6 &, $200\left(^{*}\right)$ & ,853 & 6 & 167 \\
\hline & TFD com ftalo & ,254 & 6 &, $200\left(^{*}\right)$ & ,866 & 6 & ,212 \\
\hline
\end{tabular}

* This is a lower bound of the true significance.

a Lilliefors Significance Correction 


\section{ESTATÍSTICA DESCRITIVA DOS DADOS DAS MEDIDAS DO PAQUIMETRO}

\begin{tabular}{|c|c|c|c|c|c|c|}
\hline Grupo & & $\mathrm{N}$ & Minimum & Maximum & Mean & Std. Deviation \\
\hline controle negativo & Antes de infectar & 6 & 2,1 & 2,3 & 2,233 &, 0816 \\
\hline & 02 dias após a infecção & 6 & 2,3 & 2,4 & 2,317 & ,0408 \\
\hline & 30 dias após a infecção & 6 & 2,2 & 2,4 & 2,283 & ,0753 \\
\hline & $\begin{array}{l}\text { Após } 20 \text { dias de } \\
\text { tratamento }\end{array}$ & 6 & 2,2 & 2,3 & 2,250 & ,0548 \\
\hline & Valid N (listwise) & 6 & & & & \\
\hline controle positivo & Antes de infectar & 6 & 2,2 & 2,4 & 2,250 & ,0837 \\
\hline & 02 dias após a infecção & 6 & 2,4 & 2,6 & 2,467 & ,0816 \\
\hline & 30 dias após a infecção & 6 & 2,5 & 2,7 & 2,600 & 0632 \\
\hline & $\begin{array}{l}\text { Após } 20 \text { dias de } \\
\text { tratamento }\end{array}$ & 6 & 2,6 & 2,8 & 2,667 & 0816 \\
\hline & Valid N (listwise) & 6 & & & & \\
\hline Miltefosina. $20 \mathrm{mg}$ & Antes de infectar & 6 & 2,1 & 2,4 & 2,250 & 1049 \\
\hline & 02 dias após a infecção & 6 & 2,3 & 2,6 & 2,467 & 1033 \\
\hline & 30 dias após a infecção & 6 & 2,4 & 2,7 & 2,550 & , 1049 \\
\hline & $\begin{array}{l}\text { Após } 20 \text { dias de } \\
\text { tratamento }\end{array}$ & 6 & 2,2 & 2,3 & 2,267 & ,0516 \\
\hline & Valid N (listwise) & 6 & & & & \\
\hline Miltefosina & Antes de infectar & 6 & 2,1 & 2,3 & 2,250 & ,0837 \\
\hline & 02 dias após a infecção & 6 & 2,1 & 2,3 & 2,250 & ,0837 \\
\hline & 30 dias após a infecção & 6 & 2,5 & 2,7 & 2,617 & ,0753 \\
\hline & $\begin{array}{l}\text { Após } 20 \text { dias de } \\
\text { tratamento }\end{array}$ & 6 & 2,3 & 2,5 & 2,400 & ,0894 \\
\hline & Valid N (listwise) & 6 & & & & \\
\hline TFD com ftalo & Antes de infectar & 6 & 2,2 & 2,4 & 2,250 & ,0837 \\
\hline & 02 dias após a infecção & 6 & 2,4 & 2,6 & 2,483 & ,0753 \\
\hline & 30 dias após a infecção & 6 & 2,5 & 2,7 & 2,567 & ,0816 \\
\hline & $\begin{array}{l}\text { Após } 20 \text { dias de } \\
\text { tratamento }\end{array}$ & 6 & 2,4 & 2,6 & 2,483 & ,0753 \\
\hline & Valid N (listwise) & 6 & & & & \\
\hline
\end{tabular}




\section{ANALISE DO TESTE DE NORMALIDADE VIABILIDADE CELULAR}

\begin{tabular}{|l|l|r|r|r|}
\hline \multicolumn{5}{|c|}{ Teste de Normalidade } \\
\hline \hline \multirow{2}{*}{ Grupo } & \multicolumn{3}{|c|}{ Teste Shapiro-Wilk } \\
\cline { 3 - 5 } & & Estatís tica & $\begin{array}{c}\text { Graus de } \\
\text { Liberdade }\end{array}$ & p-valor \\
\hline \multirow{4}{*}{ MTT } & Controle Negativo &, 959 & 72 &, 019 \\
\cline { 2 - 5 } & Controle Positivo &, 914 & 72 &, 000 \\
\cline { 2 - 6 } & Miltefosina. 20 mg &, 966 & 72 &, 046 \\
& + TFD com ftalo & & &, 003 \\
\cline { 2 - 6 } & Miltefosina &, 944 & 72 &, 000 \\
\hline \hline
\end{tabular}




\section{ANALISE DESCRITIVA DA VIABILIDADE CELULAR}

\begin{tabular}{|c|c|c|c|c|}
\hline Grupo & $\mathrm{N}$ & Média & $\begin{array}{l}\text { Desvio } \\
\text { Padrão }\end{array}$ & $\begin{array}{c}\text { Erro Padrão } \\
\text { da Média }\end{array}$ \\
\hline Controle Positivo & 72 & 100,0 & 30,5 & 3,6 \\
\hline Miltefosina & 72 & 41,9 & 21,8 & 2,6 \\
\hline TFD com ftalo. & 72 & 76,6 & 19,7 & 2,3 \\
\hline Miltefosina. $20 \mathrm{mg}+$ TFD com ftalo & 72 & 6,6 & 10,5 & 1,2 \\
\hline Total & 288 & 56,3 & 41,5 & 2,4 \\
\hline
\end{tabular}

